Universidade de São Paulo

Escola Superior de Agricultura "Luiz de Queiroz"

Suprimento de nitrato e amônio e a tolerância do capim tanzânia ao estresse por excesso de cobre

\author{
João Cardoso de Souza Junior
}

Dissertação apresentada para obtenção do título de Mestre em Ciências. Área de concentração: Solos e Nutrição de Plantas

Piracicaba

2016 
João Cardoso de Souza Junior

Engenheiro Agrônomo

Suprimento de nitrato e amônio e a tolerância do capim tanzânia ao estresse por excesso de cobre

Orientador:

Prof. Dr. FRANCISCO ANTONIO MONTEIRO

Dissertação apresentada para obtenção do título de Mestre em Ciências. Área de concentração: Solos e Nutrição de Plantas 


\section{Dados Internacionais de Catalogação na Publicação DIVISÃO DE BIBLIOTECA - DIBD/ESALQ/USP}

Souza Junior, João Cardoso de

Suprimento de nitrato e amônio e a tolerância do capim tanzânia ao estresse por excesso de cobre / João Cardoso de Souza Junior. - Piracicaba, 2016.

$74 \mathrm{p}$.

Dissertação (Mestrado) - - USP / Escola Superior de Agricultura "Luiz de Queiroz".

1. Enzimas antioxidantes 2. Estresse oxidativo 3. Fitorremediação 4. Fotossíntese de plantas forrageiras 5. Metabolismo do nitrogênio 6 . Nutrição mineral de forrageiras 7. Prolina 8. Toxidez por metal pesado I. Título 


\section{DEDICATÓRIA}

Aos meus pais Maria Salete Santos Rodrigues e João Cardoso de Souza, por me concederem a vida, expondo o amor incondicional e apoiando minhas escolhas em todas as etapas de minha formação acadêmica. Pelo amor, carinho, respeito e admiração que tenho por vocês, hoje me sinto realizado, com o sentimento de etapa cumprida. Pelo apoio emocional, ético e técnico em meus estudos, o título de mestre em ciências é tão meu quanto é de vocês, meus pais. O carinho e amor que sinto pelos dois me dizem que nossa relação de amor não é apenas terrena, mas infinita no universo. Por isso, dedico esta dissertação principalmente a vocês. Amo vocês dois!

Ao meu amor e paixão Aline Cristina Richart, pelo amor, carinho, presença e ensinamentos, que me motivam, me equilibram e me fazem gostar e amar você cada vez mais. Sua dedicação, perseverança e amor em tudo o que se propõe a desenvolver, tanto na vida emocional, quanto na vida sentimental, são exemplos que eu sempre tento acompanhar. Amo você!

A todos os meus familiares, especialmente os que me apoiaram para chegar até aqui. Minha madrasta Selma Venâncio, minha “irmã” Elaina Venâncio, minhas primas Sharlleny Souza e Milena Souza. Também os meus tios Wellington Rodrigues, Rosangela Rodrigues, Santana Rodrigues, Odete Cardoso, Albanita Cardoso e Lourdes Cardoso. Aos pequeninos, também dedico, em especial a Ana Vitória Rodrigues e Joao Victor Venâncio. Agradeço por também fazerem parte de mim e da minha vida. 


\section{AGRADECIMENTOS}

Agradeço a Escola Superior de Agricultura “Luiz de Queiroz” (Universidade de São Paulo), especialmente na pessoa do Prof. Dr. Francisco Antonio Monteiro, por todo o suporte estrutural, técnico e financeiro para que essa pesquisa pudesse ser desenvolvida e concluída com êxito. Diretamente agradeço ao Prof. Francisco, sobretudo pela amizade fortalecedora que me ajudou a trilhar o caminho correto, pela orientação técnica tanto na disciplina "Nutrição e Adubação de Plantas Forrageiras", quanto no desenvolvimento desta dissertação, aos sábios conselhos que me conduzem à reflexão e à obtenção da resolução dos problemas. Levo os ensinamentos para a vida.

Ao Departamento de Ciência do Solo da ESALQ/USP e aos professores da pós-graduação em Solos e Nutrição de Plantas que pude ter o prazer e a oportunidade de estar em contato nas disciplinas cursadas. Ao conhecimento técnico-científico transmitido nas disciplinas que também contribuíram sobremaneira na fundamentação teórica desta pesquisa. Agradeço também aos demais professores do programa que desenvolvem pesquisas avançadas, que somados tornam o programa de Solos e Nutrição de Plantas da ESALQ/USP referência internacional. Agradeço também ao Programa de Fisiologia e Bioquímica, na pessoa do prof. Dr. Daniel Scherer de Moura, ministrante da disciplina "Bioquímica de Plantas", ao qual sou grato pelo conhecimento técnico-científico transmitido, que também contribuiu para a fundamentação teórica desta pesquisa. Agradeço também à amiga e parceira de trabalho Dra. Roberta Corrêa Nogueirol, pós-doutoranda do Programa de Fitotecnia da ESALQ/USP, sempre presente nas etapas da pesquisa, contribuindo desde o planejamento, execução até orientação técnica do trabalho, contribuições essas fundamentais para o desenvolvimento desta dissertação.

Aos pós-graduandos do grupo de pesquisa sob orientação do prof. Francisco Monteiro, os quais contribuíram na execução do experimento e análises laboratoriais. Meus sinceros agradecimentos às doutorandas Ellen Anicésio e Janine Mesquita, pela ajuda principalmente na condução do experimento. Ao mestre Arnon Cardoso, pela ajuda em várias etapas da execução do experimento. Ao mestrando Leandro Vieira, pela valiosa ajuda nas determinações em laboratório. Ao estagiário João Paulo Leme, principalmente pelo suporte laboratorial na organização dos equipamentos e reagentes, assim como na ajuda em etapas da condução do experimento. À estagiária Paula Menegale, que mesmo participando do grupo na fase final desse trabalho, também contribuiu dando suporte às análises laboratoriais.

Agradeço sobremaneira a Fundação de Amparo à Pesquisa do Estado de São Paulo (FAPESP) pela concessão de bolsa de estudos nos anos de 2016/2017 e ao financiamento da pesquisa, que foram fundamentais para a produção e conclusão com êxito dessa dissertação. Finalmente, agradeço também ao Conselho Nacional de Desenvolvimento Científico e Tecnológico (CNPq) pela concessão de bolsa de estudos no ano de 2015.

A todos os que contribuíram para a conclusão desse trabalho, meus sinceros agradecimentos. 
EPÍGRAFE

So close no matter how far

Couldn't be much more from the heart

Forever trusting who we are

And nothing else matters

Nothing Else Matters - James Hetfield \& Lars Ulrich (Metallica) 


\section{SUMÁRIO}

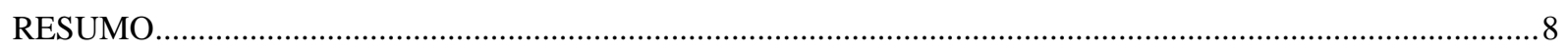

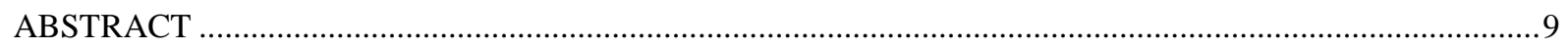

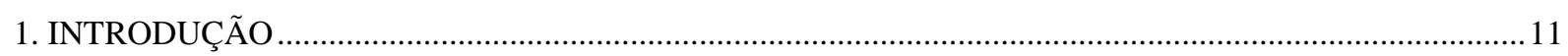

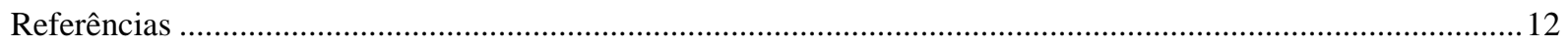

2. PROPORÇÃO DE NITRATO E AMÔNIO ALTERA A HOMEOSTASE NUTRICIONAL E A PRODUÇÃO DO CAPIM TANZÂNIA EM CONDIÇÃO DE ESTRESSE POR EXCESSO DE COBRE …………................15

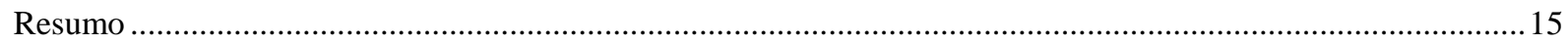

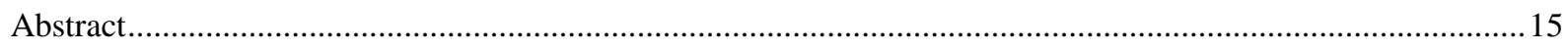

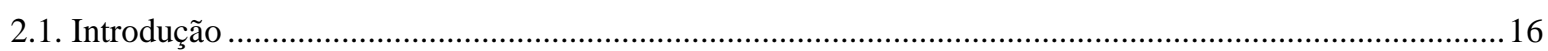

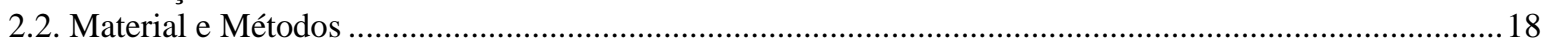

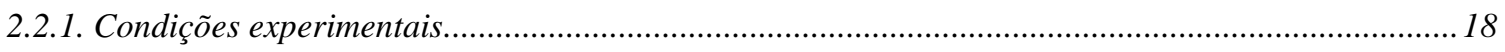

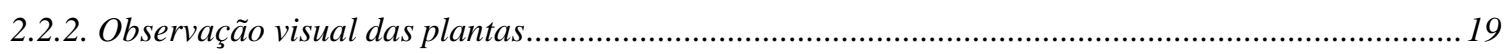

2.2.3. Determinações de $\mathrm{Cu}, \mathrm{NO}_{3}{ }^{-}, \mathrm{NH}_{4}{ }^{+}$e $\mathrm{N}_{\text {total }}$ em tecido vegetal ........................................................ 19

2.2.4. Atividade de enzimas de assimilação do nitrogênio........................................................................... 19

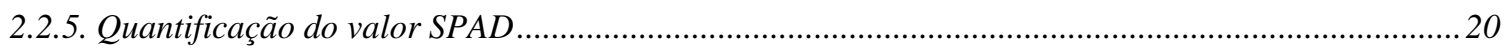

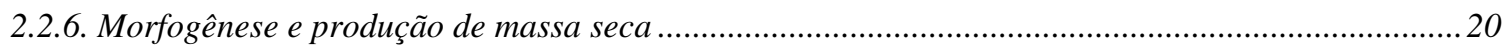

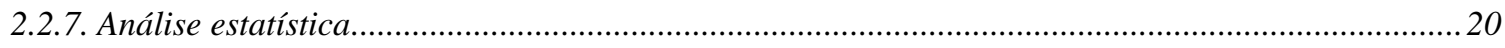

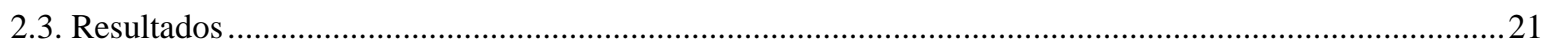

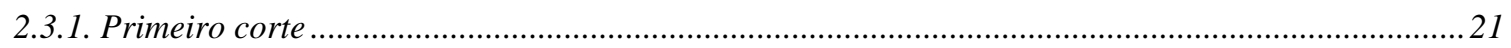

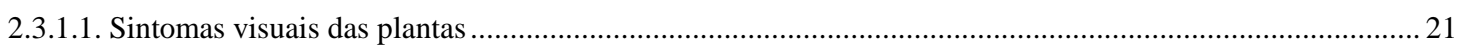

2.3.1.2. Concentração e acúmulo de minerais na parte aérea da planta................................................................23

2.3.1.3. Atividade das enzimas envolvidas na assimilação de nitrogênio ...............................................................2 25

2.3.1.4. Valor SPAD nas folhas diagnósticas, morfogênese e produção de massa da parte aérea.............................26

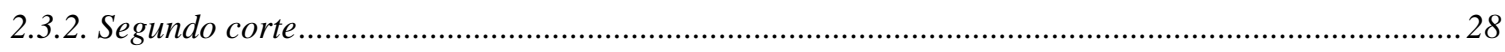

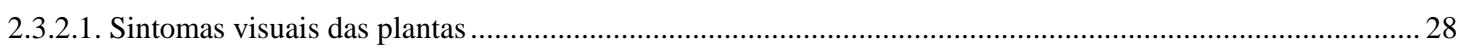

2.3.2.2. Concentração e acúmulo de minerais na parte aérea ....................................................................................29

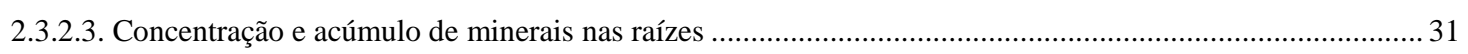

2.3.2.4. Atividades das enzimas envolvidas na assimilação de nitrogênio .............................................................. 34

2.3.2.5. Valor SPAD das folhas diagnósticas, morfogênese e produção de massa.................................................... 34

2.3.2.6. Produção de massa de raízes e superfície radicular.................................................................................. 35

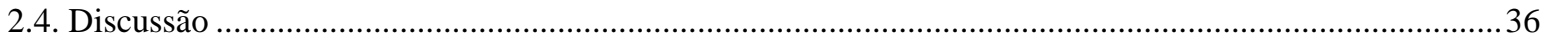

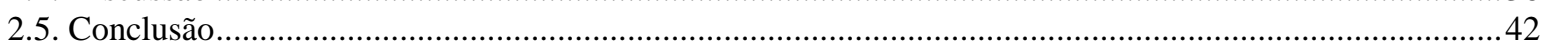

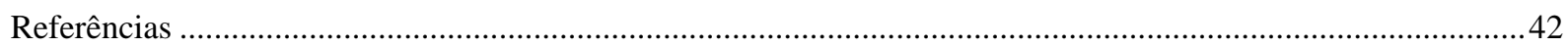

3. FORNECIMENTO DE NITRATO E AMÔNIO AUMENTA FITOEXTRAÇÃO DE COBRE E INDUZ ATIVIDADE DA SUPERÓXIDO DISMUTASE E SÍNTESE DE PROLINA NO CAPIM TANZÂNIA ...........45

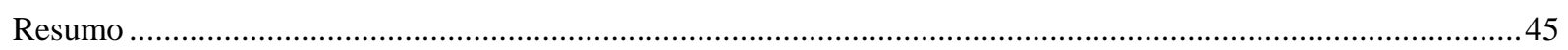

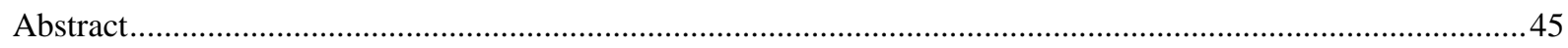

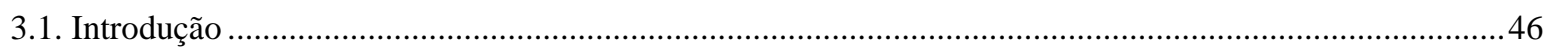

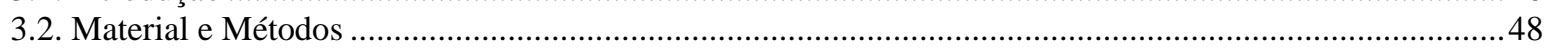

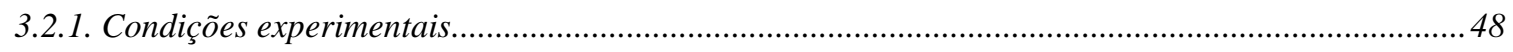

3.2.2. Determinação de Cu no tecido vegetal ........................................................................................... 49 


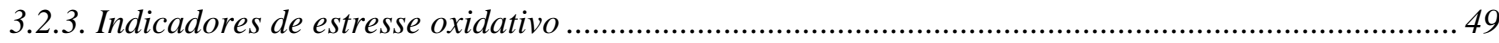

3.2.4. Extração e quantificação de proteínas ................................................................................................. 50

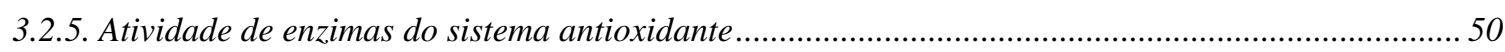

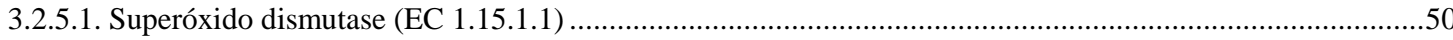

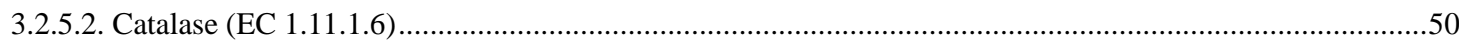

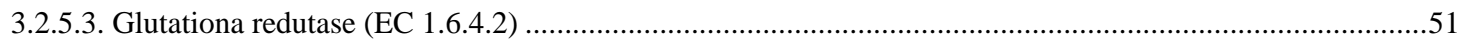

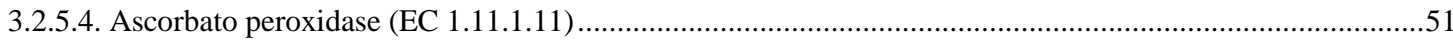

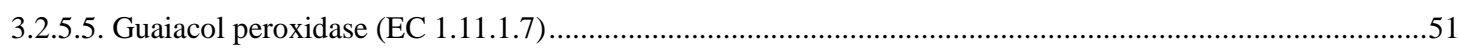

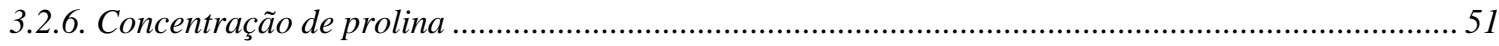

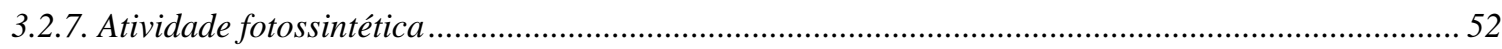

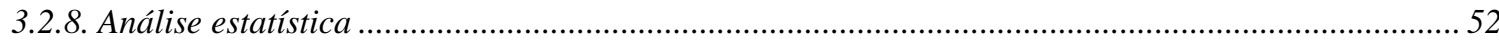

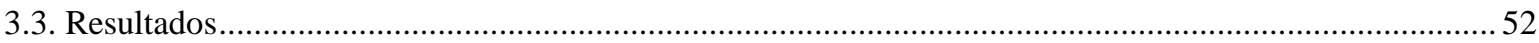

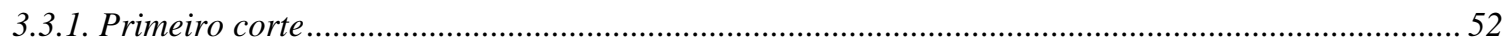

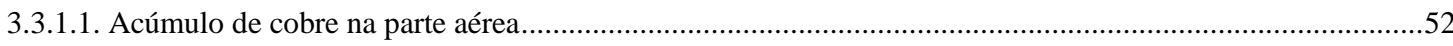

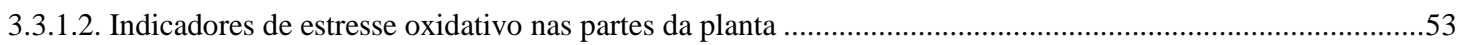

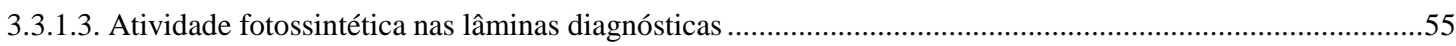

3.3.1.4. Concentração de prolina nas partes da planta ........................................................................................56

3.3.1.5. Atividade de enzimas antioxidantes na parte aérea ....................................................................................56

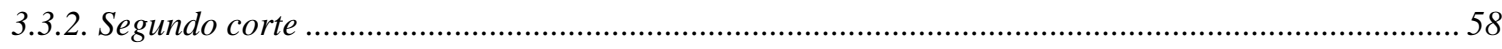

3.3.2.1. Acúmulo de $\mathrm{Cu}$ na parte aérea e nas raízes .....................................................................................58

3.3.2.2. Indicadores de estresse oxidativo na parte aérea e nas raízes ...................................................................59

3.3.2.3. Atividade fotossintética nas lâminas diagnósticas .....................................................................................60

3.3.2.4. Concentração de prolina na parte aérea e nas raízes ................................................................................61

3.3.2.5. Atividade de enzimas antioxidante nas partes da planta ........................................................................61

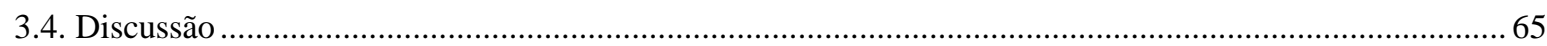

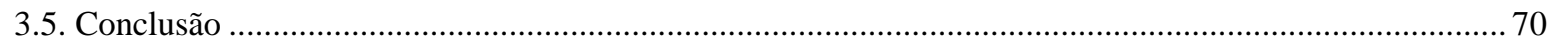

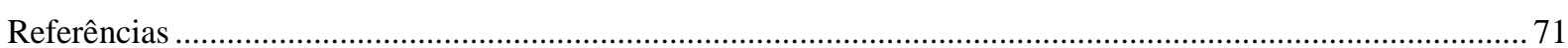


RESUMO

\title{
Suprimento de nitrato e amônio e a tolerância do capim tanzânia ao estresse por excesso de cobre
}

\begin{abstract}
O suprimento de proporções de nitrato $\left(\mathrm{NO}_{3}{ }^{-}\right)$e amônio $\left(\mathrm{NH}_{4}{ }^{+}\right)$no meio de crescimento pode otimizar o metabolismo e o crescimento do Panicum maximum. A toxidez de cobre $(\mathrm{Cu})$ causa estresse oxidativo nas plantas, afetando o metabolismo, a fotossíntese e a produção de massa. Não há pesquisas associando proporções de $\mathrm{NO}_{3}{ }^{-} / \mathrm{NH}_{4}{ }^{+}$no alívio do estresse por $\mathrm{Cu}$ em plantas. $\mathrm{O}$ objetivo foi avaliar o efeito da toxidez de $\mathrm{Cu}$ no metabolismo, nutrição mineral, fotossíntese e produção do capim tanzânia, assim como o papel de proporções de $\mathrm{NO}_{3}{ }^{-} / \mathrm{NH}_{4}{ }^{+}$no alívio dessa toxidez. $\mathrm{O}$ delineamento experimental foi de blocos ao acaso em arranjo fatorial $3 \times 4 \mathrm{com}$ seis repetições, sendo três destinadas à avaliação dos atributos metabólicos e fisiológicos e outras três aos atributos nutricionais e produtivos. Os fatores empregados foram: proporções de $\mathrm{NO}_{3}{ }^{-} / \mathrm{NH}_{4}{ }^{+}(100 / 0 ; 70 / 30 \mathrm{e}$ 50/50) combinadas com doses de $\mathrm{Cu}\left(0,3 ; 250 ; 500\right.$ e $\left.1000 \mu \mathrm{mol} \mathrm{L}^{-1}\right)$ em solução nutritiva. Foram avaliados dois períodos de crescimento das plantas, sendo o primeiro com exposição ao $\mathrm{Cu}$ e o segundo sem exposição ao $\mathrm{Cu}$. No primeiro corte as plantas supridas com $70 / 30 \mathrm{de} \mathrm{NO}_{3}{ }^{-} / \mathrm{NH}_{4}{ }^{+}$e $\mathrm{Cu}$ de $1000 \mu \mathrm{mol} \mathrm{L}{ }^{-1}$ apresentaram maior concentração de $\mathrm{Cu}$ nas folhas recém-expandidas (LR) e maior acúmulo de $\mathrm{Cu}$ na biomassa, maior concentração de $\mathrm{NH}_{4}{ }^{+}$nas $\mathrm{LR}$, maior acúmulo de $\mathrm{NH}_{4}{ }^{+}$na parte aérea, maior atividade da glutamina sintetase nas LR, maior concentração de prolina nas LR, maior atividade da enzima superóxido dismutase (SOD) nas partes do capim e menor produção de biomassa. No capim suprido com 100/0 de $\mathrm{NO}_{3}{ }^{-} / \mathrm{NH}_{4}{ }^{+}$e $\mathrm{Cu}$ de $1000 \mu \mathrm{mol} \mathrm{L}{ }^{-1}$ foram obtidos menor concentração de $\mathrm{Cu}$ nas $\mathrm{LR}$ e menor acúmulo de $\mathrm{Cu}$ na parte aérea, mas a concentração e o acúmulo desse metal nas raízes foram incrementados mesmo nas mais baixas doses de $\mathrm{Cu}$. As plantas crescidas com $\mathrm{N}$ na forma de $\mathrm{NO}_{3}{ }^{-}$ainda apresentaram maior concentração de $\mathrm{NO}_{3}{ }^{-}$nas $\mathrm{LR}$, maior acúmulo de $\mathrm{NO}_{3}{ }^{-}$nas raízes, maior acúmulo de $\mathrm{N}$ total, maior atividade da nitrato redutase nas LR, maior condutância estomática e maior produção de biomassa. No capim recebendo $100 / 0$ de $\mathrm{NO}_{3}{ }^{-} / \mathrm{NH}_{4}{ }^{+}$ também ocorreu menor atividade da SOD e menor concentração de prolina nas partes da planta. A concentração de malondialdeído foi menor na mais elevada dose de $\mathrm{Cu}$, assim como a taxa de transpiração, a eficiência do fotossistema II, a taxa de transporte de elétrons e a taxa de assimilação de $\mathrm{CO}_{2}$. A atividade da catalase, guaiacol peroxidase, ascorbato peroxidase e glutationa redutase foram ativadas principalmente nas raízes, sendo maiores na mais elevada dose de $\mathrm{Cu}$. A toxidez de $\mathrm{Cu}$ afeta negativamente o metabolismo, a nutrição mineral, a fisiologia e a produção do capim tanzânia, mas as proporções de $\mathrm{NO}_{3}{ }^{-} / \mathrm{NH}_{4}{ }^{+}$alteram essa toxidez. O emprego de $\mathrm{N}$ na forma de $\mathrm{NO}_{3}{ }^{-}$é estratégia de maior potencial de uso em plantas com elevado estresse por $\mathrm{Cu}$. Entretanto, a combinação de $\mathrm{NO}_{3}{ }^{-}$ ao $\mathrm{NH}_{4}{ }^{+}$no meio de crescimento em situação de moderado estresse por $\mathrm{Cu}$ é estratégica para maior fitoextração desse metal.
\end{abstract}

Palavras-chave: Enzimas antioxidantes; Estresse oxidativo; Fitorremediação; Fotossíntese de plantas forrageiras; Metabolismo do nitrogênio; Nutrição mineral de gramíneas forrageiras; Prolina; Toxidez por metal 


\section{ABSTRACT \\ Nitrate and ammonium proportions and tanzânia guineagrass tolerance to stress by excess copper}

The supply of nitrate $\left(\mathrm{NO}_{3}{ }^{-}\right)$and ammonium $\left(\mathrm{NH}_{4}{ }^{+}\right)$proportions in the growth medium can optimize the metabolism and growth of Panicum maximum. Copper $(\mathrm{Cu})$ toxicity causes oxidative stress in plants, affecting metabolism, photosynthesis and biomass production. There are no researchs associating proportions of $\mathrm{NO}_{3}-/ \mathrm{NH}_{4}{ }^{+}$for alleviating $\mathrm{Cu}$ stress toxicity. The objective was to evaluate the effect of $\mathrm{Cu}$ toxicity on metabolism, mineral nutrition, photosynthesis and dry matter production, as well as the role of $\mathrm{NO}_{3}{ }^{-} / \mathrm{NH}_{4}{ }^{+}$proportions in alleviating such toxicity. The experimental was carried out in randomized complete block design in a $3 \times 4$ factorial with six replications. Three replications were used to evaluated metabolic and physiological attributes and other three to determine nutrition and productive attributes. The factors were three proportions of $\mathrm{NO}_{3}{ }^{-} / \mathrm{NH}_{4}{ }^{+}$ $\left(100 / 0,70 / 30\right.$ and 50/50) combined with four rates of $\mathrm{Cu}\left(0.3,250,500\right.$ and $\left.1000 \mathrm{mmol} \mathrm{L}^{-1}\right)$ in nutrient solution. Two plant growth periods evaluated, being the first with plants exposure to $\mathrm{Cu}$ and the second without the exposure to $\mathrm{Cu}$. In the first cut, plants supplied with $70 / 30$ of $\mathrm{NO}_{3}{ }^{-} / \mathrm{NH}_{4}{ }^{+}$ proportions and $\mathrm{Cu}$ rates of $1000 \mu \mathrm{mol} \mathrm{L}{ }^{-1}$ showed high $\mathrm{Cu}$ concentration in recently fully expanded leaf laminae (LR), high $\mathrm{Cu}$ accumulation in the biomass, high $\mathrm{NH}_{4}{ }^{+}$concentration in $\mathrm{LR}$, high $\mathrm{NH}_{4}{ }^{+}$ accumulation in shoots, high glutamine synthetase activity in LR, higher proline concentration in LR, high superoxide dismutase (SOD) activity in parts of grass and low shoot dry matter production. In the grass supplied with $100 / 0$ of $\mathrm{NO}_{3}-/ \mathrm{NH}_{4}{ }^{+}$and $\mathrm{Cu}$ of $1000 \mu \mathrm{mol} \mathrm{L}{ }^{-1}$ it was found a low $\mathrm{Cu}$ concentration in LR and low $\mathrm{Cu}$ accumulation in shoots, but the concentration and accumulation of this metal in roots were increased even in lower $\mathrm{Cu}$ rate. Plants supply with $100 / 0$ of $\mathrm{NO}_{3}{ }^{-} / \mathrm{NH}_{4}{ }^{+}$also showed high $\mathrm{NO}_{3}{ }^{-}$concentration in $\mathrm{LR}$, high $\mathrm{NO}_{3}{ }^{-}$accumulation in roots, high $\mathrm{N}$ accumulation in shoots, high nitrate reductase activity in LR, high stomatal conductance and high biomass production. In the grass supplied with $100 / 0$ of $\mathrm{NO}_{3}{ }^{-} / \mathrm{NH}_{4}{ }^{+}$, there was low SOD activity and low proline concentration in shoots. The concentration of malondialdehyde was low at the high $\mathrm{Cu}$ rate, as well as the transpiration rate, photosystem II efficiency, electron transport rate and $\mathrm{CO}_{2}$ assimilation rate. Catalase, guaiacol peroxidase, ascorbate peroxidase and glutathione reductase activities were activated mainly in roots, being high in high $\mathrm{Cu}$ rate. $\mathrm{Cu}$ toxicity negatively affects metabolism, mineral nutrition, physiology and dry matter productions of tanzania guineagrass, but $\mathrm{NO}_{3}^{-} / \mathrm{NH}_{4}{ }^{+}$ proportions change this toxicity. The only use of $\mathrm{NO}_{3}-$ in the $\mathrm{N}$ supply is a strategy of great potential to be use in plants with of high $\mathrm{Cu}$ stress. However, combinations of $\mathrm{NO}_{3}{ }^{-}$with $\mathrm{NH}_{4}{ }^{+}$in the growth medium when plants suffer moderate $\mathrm{Cu}$ stress is strategic for great metal phytoextraction.

Keywords: Antioxidant enzymes; Mineral nutrition of forage grasses; Nitrogen metabolism; Oxidative stress; Phytoremediation; Plant forage physiology; Heavy metal toxicity 


\section{INTRODUÇÃO}

O Brasil possui extensa área destinada as pastagens, as quais ocupam aproximadamente 196 milhões de hectares ou 71\% da área agrícola do país, compondo 23\% do território nacional (Faostat, 2012). As pastagens no Brasil sustentam quase totalmente a produção de 213 milhões de cabeças de bovinos e bubalinos (FAO, 2012), sendo a principal fonte nutricional para a produção desses animais. Do total de área de pasto plantado no Brasil, a maior parte está ocupada pelas gramíneas forrageiras tropicais, a exemplo da espécie Panicum maximum reconhecida por sua elevada qualidade de forragem (Fonseca e Martuscello, 2010).

Dentre os cultivares de importância comercial de P. maximum destaca-se o capim tanzânia, o qual cresce formando touceiras que, após o pastejo, rebrotam rapidamente e conferem a esta gramínea grande potencial de fitoextração de nutrientes. O fato do capim tanzânia apresentar elevada importância econômica deve-se também à alta capacidade produtiva dessa gramínea, modulada especialmente pelo uso do nitrogênio $(\mathrm{N})$ nas formas iônicas absorvíveis pelas raízes de plantas, como nitrato e amônio $\left(\mathrm{NO}_{3}^{-}\right.$e $\mathrm{NH}_{4}{ }^{+}$) (Santos et al., 2013). A adubação nitrogenada em doses elevadas possibilita a expressão do pleno potencial produtivo da planta e num contexto de estresse abiótico pode favorecer a rusticidade e a tolerância necessária para combater tal condição adversa (CarrascoGil et al., 2012), o que possibilita a identificação de outros usos potenciais para o capim tanzânia, como o voltado à fitorremediação de metais (Gilabel et al., 2014).

A tolerância a elementos tóxicos, pré-requisito para a fitorremediação de metais, foi previamente confirmada para o capim tanzânia, com relação à tolerância ao cobre $(\mathrm{Cu})$, cádmio $(\mathrm{Cd})$ e bário $(\mathrm{Ba})$ (Monteiro et al., 2011; Gilabel et al., 2014; Rabêlo et al., 2016). Isto se soma ao fato do capim tanzânia possuir outros potenciais prérequisitos para ser planta fitorremediadora, especialmente sob nutrição adequada com formas iônicas de N, tais como: fácil estabelecimento, crescimento acelerado em condições tropicais, capacidade de rebrotação, alta produção de biomassa e extração de nutrientes. Portanto, essas características possibilitam estudos para o P. maximum no intuito de identificar os limites quanto à tolerância e acúmulo de $\mathrm{Cu}$ e sua respectiva interação com o suprimento de proporções de $\mathrm{NO}_{3}-/ \mathrm{NH}_{4}{ }^{+}$no meio de crescimento. Estudos indicam melhorias no crescimento e incremento na

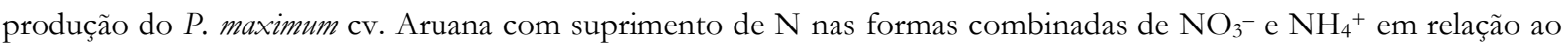
suprimento exclusivo com $\mathrm{N}$ na forma de $\mathrm{NO}_{3}{ }^{-}$(Santos et al., 2013), o que pode favorecer a fitoextração de minerais e propiciar maior persistência do capim em condições ambientais de toxidez por $\mathrm{Cu}$.

Mesmo sendo um micronutriente de plantas, o $\mathrm{Cu}$ é um dos principais metais com alto potencial de contaminação ambiental e diversos estudos têm revelado novas áreas no mundo que estão contaminadas por $\mathrm{Cu}$, como consequência dos impactos da exploração de minérios (Cassella et al., 2007; Wu et al., 2011), do uso intensivo de fungicidas cúpricos em áreas agrícolas (Fernández-Calviño et al., 2010; Nogueirol et al., 2010; Wightwick et al., 2013) e do descarte inadequado de resíduos (Nogueirol et al., 2010; Nogueirol et al., 2013). Nesse sentido, os esforços para elucidar o papel de proporções de $\mathrm{NO}_{3}{ }^{-} / \mathrm{NH}_{4}{ }^{+}$em plantas expostas ao excesso de $\mathrm{Cu}$ são de extrema relevância, uma vez que podem nortear a adubação nitrogenada em programas de fitorremediação de áreas contaminadas por $\mathrm{Cu}$ e favorecer a extração do metal contaminante do solo.

A literatura científica não trata especificamente do efeito das proporções de $\mathrm{NO}_{3}{ }^{-} / \mathrm{NH}_{4}{ }^{+}$associada ao excesso de $\mathrm{Cu}$ ou outro metal pesado com o objetivo de favorecer o potencial fitorremediador, tampouco testando as hipóteses a partir da avaliação de atributos metabólicos, fisiológicos, nutricionais e produtivos. Apesar disso, a sistematização do conhecimento gerado até o presente momento sugere que proporções adequadas de $\mathrm{NO}_{3}{ }^{-} / \mathrm{NH}_{4}{ }^{+}$ para condições abióticas adversas, podem modular a absorção de nutrientes e, com isso, o potencial fitoextrator das 
plantas. Consequentemente, as proporções de $\mathrm{NO}_{3}^{-} / \mathrm{NH}_{4}{ }^{+}$também podem induzir alterações metabólicas e fisiológicas que culminem em efeitos de alívio de estresse causado por $\mathrm{Cu}$ no capim tanzânia. Apesar disso, tais respostas são desconhecidas e não há relatos diretos que mostrem os possíveis mecanismos envolvidos. Nesse sentido, testa-se a hipótese que proporções de $\mathrm{NO}_{3}{ }^{-} / \mathrm{NH}_{4}{ }^{+}$alteram a fitoextração por Cu e a tolerância do capim tanzânia ao estresse causado por esse metal com o objetivo de indicar caminhos que possam elucidar os mecanismos envolvidos.

$\mathrm{O}$ intuito de estudar o estresse causado por toxidez de $\mathrm{Cu}$ no capim tanzânia deve-se aos seguintes aspectos: (1) A contaminação do solo por $\mathrm{Cu}$ é problema ambiental atual e generalizado no mundo, com forte impacto na saúde da população humana, uma vez que é bioacumulativo nos tecidos e entra na cadeia alimentar a partir da ingestão de alimentos cultivados em ambientes contaminados com $\mathrm{Cu}$, o que estimula estudos com o objetivo de propor alternativas de descontaminação desses ambientes (Keunen et al., 2011); (2) O Cu é essencial aos seres vivos, contudo é extremamente tóxico quando em limites acima dos recomendados, especialmente para os humanos, podendo causar Alzheimer, redução da cognição e neurogeneração (Brewer, 2010); (3) A quantidade de áreas contaminadas por $\mathrm{Cu}$ vem crescendo em ritmo acelerado nos anos recentes, assim como o estresse causado pelo metal nos organismos vivos (Fernández-Calviño et al., 2010; Nogueirol et al., 2010; Wightwick et al., 2013); (4) Poucas plantas são capazes de viver em solo contaminado com $\mathrm{Cu}$, dada a elevada fitotoxidez do excesso da disponibilidade desse metal, o que coloca em risco a produção de alimentos e a segurança alimentar da população; (5) Apesar da existência de estudos envolvendo estresse por $\mathrm{Cu}$ em plantas, escassos são os trabalhos para as gramíneas forrageiras e não há quaisquer relatos que busquem elucidar os mecanismos da adequada nutrição com formas iônicas de $\mathrm{N}$ para o alívio de estresse causado por $\mathrm{Cu}$, o que dificulta o desenvolvimento de programas específicos de adubação nitrogenada para estas plantas em condições de solo contaminado.

O objetivo geral foi avaliar o efeito do suprimento de combinações de $\mathrm{NO}_{3}-/ \mathrm{NH}_{4}{ }^{+}$no alívio de estresse induzido por toxidez de $\mathrm{Cu}$ em plantas de Panicum maximum cv. Tanzânia cultivadas em solução nutritiva, utilizando indicadores metabólicos, fisiológicos, nutricionais e produtivos.

\section{Referências}

Brewer, G.J., 2010. Risks of copper and iron toxicity during aging in humans. Chem. Res. Toxicol. 23, 319-326. doi:10.1021/tx900338d

Carrasco-Gil, S., Estebaranz-Yubero, M., Medel-Cuesta, D., Millán, R., Hernández, L.E., 2012. Influence of nitrate fertilization on $\mathrm{Hg}$ uptake and oxidative stress parameters in alfalfa plants cultivated in a $\mathrm{Hg}$-polluted soil. Environ. Exp. Bot. 75, 16-24. doi:10.1016/j.envexpbot.2011.08.013

Cassella, R.J., Wagener, A.L.R., Santelli, R.E., Wagener, K., Tavares, L.Y., 2007. Distribution of copper in the vicinity of a deactivated mining site at Carajás in the Amazon region of Brazil. J. Hazard. Mater. 142, 543-549. doi:10.1016/j.jhazmat.2006.08.060

Faostat. Disponível em: <http://faostat.fao.org/>. Acesso em: 16 jul. 2014

Fernández-Calviño, D., Soler-Rovira, P., Polo, A., Díaz-Raviña, M., Arias-Estévez, M., Plaza, C., 2010. Enzyme activities in vineyard soils long-term treated with copper-based fungicides. Soil Biol. Biochem. 42, 2119-2127. doi:10.1016/j.soilbio.2010.08.007

Fonseca, D.M., Martuscello, J.A., 2010. Plantas forrageiras. Editora UFV: Viçosa. 537 p

Gilabel, A.P., Nogueirol, R.C., Garbo, A.I., Monteiro, F.A., 2014. The role of sulfur in increasing guinea grass tolerance of copper phytotoxicity. Water. Air. Soil Pollut. 225, 1806-1816. doi:10.1007/s11270-013-1806-8 
Keunen, E., Remans, T., Bohler, S., Vangronsveld, J., Cuypers, A., 2011. Metal-induced oxidative stress and plant mitochondria. Int. J. Mol. Sci. 12, 6894-6918. doi:10.3390/ijms12106894

Nogueirol, R.C., Alleoni, L.R.F., Nachtigall, G.R., Melo, G.W., 2010. Sequential extraction and availability of copper in $\mathrm{Cu}$ fungicide-amended vineyard soils from Southern Brazil. J. Hazard. Mater. 181, 931-937. doi:10.1016/j.jhazmat.2010.05.102

Nogueirol, R.C., de Melo, W.J., Bertoncini, E.I., Alleoni, L.R.F., 2013. Concentrations of Cu, Fe, Mn, and Zn in tropical soils amended with sewage sludge and composted sewage sludge. Environ. Monit. Assess. 185, 2929_ 2938. doi:10.1007/s10661-012-2761-3

Rabêlo, F.H.S., Azevedo, R.A., Monteiro, F.A., 2016. Proper supply of S increases GSH synthesis in the establishment and reduces tiller mortality during the regrowth of Tanzania guinea grass used for Cd phytoextraction. J. Soils Sediments. 1, 1-10. doi:10.1007/s11368-016-1429-y

Santos, J.H.S., De Bona, F.D., Monteiro, F.A., 2013. Growth and productive responses of tropical grass Panicum maximum to nitrate and ammonium supply. Rev. Bras. Zootec. 42, 622-628. doi:10.1590/S151635982013000900003

Silveira, C.P., Monteiro, F.A., 2011. Influence of nitrogen and calcium fertilizations on morphological and productive characteristics of tanzania guineagrass roots grown in nutrient solution. Rev. Bras. Zootec. 40, 47-52. doi:10.1590/S1516-35982011000100007

Wightwick, A.M., Salzman, S.A., Reichman, S.M., Allinson, G., Menzies, N.W., 2013. Effects of copper fungicide residues on the microbial function of vineyard soils. Environ. Sci. Pollut. Res. 20, 1574-1585. doi:10.1007/s11356-012-1114-7

Wu, F., Liu, Y., Xia, Y., Shen, Z., Chen, Y., 2011. Copper contamination of soils and vegetables in the vicinity of Jiuhuashan copper mine, China. Environ. Earth Sci. 64, 761-769. doi:10.1007/s12665-010-0897-4 


\title{
2. PROPORÇÃO DE NITRATO E AMÔNIO ALTERA A HOMEOSTASE NUTRICIONAL E A PRODUÇÃO DO CAPIM TANZÂNIA EM CONDIÇÃO DE ESTRESSE POR EXCESSO DE COBRE
}

\section{Resumo}

\begin{abstract}
O suprimento de nitrogênio $(\mathrm{N})$ nas formas de nitrato $\left(\mathrm{NO}_{3}^{-}\right)$e amônio $\left(\mathrm{NH}_{4}^{+}\right)$pode alterar a concentração de metais na planta, a atividade de enzimas envolvidas na assimilação de $\mathrm{N}$, o crescimento e a produção do Panicum maximum cv. Tanzânia. Não há relatos desses efeitos em situação de toxidez por $\mathrm{Cu}$. O objetivo foi avaliar as desordens causadas pela toxidez de $\mathrm{Cu}$ nos atributos nutricionais, morfológicos e produtivos do capim tanzânia, assim como o papel das proporções de $\mathrm{NO}_{3}{ }^{-} / \mathrm{NH}_{4}{ }^{+}$no alívio dessa toxidez. O delineamento experimental foi de blocos completos ao acaso, em fatorial $3 \times 4$ com três repetições. Os fatores foram três proporções de $\mathrm{NO}_{3}{ }^{-} / \mathrm{NH}_{4}{ }^{+}(100 / 0 ; 70 / 30$ e 50/50) combinadas com quatro doses de $\mathrm{Cu}\left(0,3 ; 250 ; 500\right.$ e $\left.1000 \mu \mathrm{mol} \mathrm{L}^{-1}\right)$ em solução nutritiva. Foram avaliados dois períodos de crescimento das plantas, sendo o primeiro com exposição das plantas ao $\mathrm{Cu}$ e o segundo sem essa exposição. A maior concentração de $\mathrm{Cu}$ nas folhas diagnósticas (LR) no primeiro corte foi constatada nas plantas cultivadas com 70/30 de $\mathrm{NO}_{3}{ }^{-} / \mathrm{NH}_{4}{ }^{+}$e $\mathrm{Cu}$ de 1000 $\mu \mathrm{mol} \mathrm{L}{ }^{-1}$. Essa combinação proporcionou maior concentração de $\mathrm{NH}_{4}{ }^{+}$nas $\mathrm{LR}$, maior acúmulo de $\mathrm{NH}_{4}{ }^{+}$na parte aérea, maior atividade da enzima glutamina sintetase nas LR, menor valor SPAD e menor produção de biomassa. As plantas que receberam $\mathrm{N}$ na forma de $\mathrm{NO}_{3}{ }^{-}$, no primeiro corte apresentaram menor concentração de $\mathrm{Cu}$ nas $\mathrm{LR}$, maior valor SPAD, maior concentração de $\mathrm{NO}_{3}{ }^{-}$nas LR e maior acúmulo de $\mathrm{NO}_{3}{ }^{-}$nas raízes quando expostas ao $\mathrm{Cu}$ de $1000 \mu \mathrm{mol} \mathrm{L} \mathrm{L}^{-1}$. O suprimento com $\mathrm{N}$ na forma de $\mathrm{NO}_{3}{ }^{-}$possibilitou maior atividade da nitrato redutase $(\mathrm{NR})$ nas $\mathrm{LR}$ e maior acúmulo de $\mathrm{N}$ total na parte aérea na condição de $\mathrm{Cu}$ de $1000 \mu \mathrm{mol} \mathrm{L}{ }^{-1}$. No segundo corte, os efeitos foram associados principalmente à não rebrotação e posterior morte das plantas que receberam 70/30 de $\mathrm{NO}_{3}-\mathrm{NH}_{4}{ }^{+}$e $\mathrm{Cu}$ de $1000 \mu \mathrm{mol} \mathrm{L}{ }^{-1}$, o que não ocorreu quando as plantas foram expostas ao $\mathrm{Cu}$ de $500 \mu \mathrm{mol} \mathrm{L}^{-1}$. As plantas recebendo com $70 / 30$ de $\mathrm{NO}_{3}{ }^{-} / \mathrm{NH}_{4}{ }^{+}$e $\mathrm{Cu}$ de $500 \mu \mathrm{mol} \mathrm{L}^{-1}$, no segundo corte apresentaram alta concentração de $\mathrm{Cu}$ nas LR, menor concentração de $\mathrm{N}$ total, menor acúmulo de $\mathrm{N}$ total na parte aérea, menor número de folhas, menor número de perfilhos e menor produção de massa seca. As desordens causadas pela toxidez de $\mathrm{Cu}$ no capim tanzânia dependem das proporções de $\mathrm{NO}_{3}-/ \mathrm{NH}_{4}{ }^{+}$e da dose desse metal na solução nutritiva. $\mathrm{O}$ suprimento com $\mathrm{N}$ exclusivo na forma de $\mathrm{NO}_{3}^{-}$mostrou ser estratégia que garante maior permanência do capim em ambiente de alta concentração de $\mathrm{Cu}$ no meio de cultivo, ao passo que o suprimento combinando $\mathrm{NO}_{3}{ }^{-}$ao $\mathrm{NH}_{4}{ }^{+}$é estratégica para aumentar a concentração de Cu na biomassa, em meio de crescimento de crescimento com moderada toxidez de $\mathrm{Cu}$.
\end{abstract}

Palavras-chave: Adubação nitrogenada; Glutamina sintetase; Nitrato redutase; Nutrição mineral de gramíneas forrageiras; Toxidez de cobre; Valor SPAD

\section{Abstract}

Nitrogen (N) supply as nitrate $\left(\mathrm{NO}_{3}^{-}\right)$and ammonium $\left(\mathrm{NH}_{4}{ }^{+}\right)$may changes metal concentration in plants, the activity of enzymes involved in $\mathrm{N}$ assimilation, growth and production of Panicum maximum cv. Tanzania. There are no reports on these effects wen plants suffer Cu toxicity. The objective was to evaluate the $\mathrm{Cu}$ toxicity disorders on nutritional, morphological and productive attributes of tanzania guineagrass, as well as the role of $\mathrm{NO}_{3}{ }^{-} / \mathrm{NH}_{4}{ }^{+}$proportions in alleviating such toxicity. The experiment was set in a randomized completed block design, in a $3 \times 4$ factorial with three replications. The factors used were three $\mathrm{NO}_{3}-/ \mathrm{NH}_{4}{ }^{+}$proportions (100/0, 70/30 and 50/50) combined with four $\mathrm{Cu}$ rates $(0.3,250,500$ and $1000 \mu \mathrm{mol} \mathrm{L}-1)$ in nutrient solution. Plants were grown for two periods, the first carried out with $\mathrm{Cu}$ exposure and the second one without $\mathrm{Cu}$ exposure. High $\mathrm{Cu}$ concentration in diagnostic leaves (LR) was found in the first harvest in plants grown with 70/30 of $\mathrm{NO}_{3}{ }^{-} / \mathrm{NH}_{4}{ }^{+}$and $\mathrm{Cu} 1000 \mu \mathrm{mol} \mathrm{L}{ }^{-1}$. This combination resulted in high $\mathrm{NH}_{4}{ }^{+}$concentration in LR, high $\mathrm{NH}_{4}{ }^{+}$accumulation in shoots, high glutamine synthetase activity in LR, low SPAD reading and low biomass production. Plants that received $\mathrm{N}$ only as $\mathrm{NO}_{3}{ }^{-}$in the first growth had low $\mathrm{Cu}$ 
concentration in LR, high SPAD reading, high $\mathrm{NO}_{3}^{-}$concentration in $\mathrm{LR}$ and high $\mathrm{NO}_{3}{ }^{-}$ accumulation in roots, when exposed to $\mathrm{Cu} 1000 \mu \mathrm{mol} \mathrm{L}{ }^{-1}$. The $\mathrm{N}$ supply as $\mathrm{NO}_{3}{ }^{-}$resulted in high nitrate reductase (NR) activity in LR and high $\mathrm{N}$ accumulation in shoots in condition of $\mathrm{Cu} 1000$ $\mu \mathrm{mol} \mathrm{L}-1$. At the second harvest, the effects were mainly associated to non-regrowth and subsequent death of plants that received 70/30 of $\mathrm{NO}_{3}-/ \mathrm{NH}_{4}{ }^{+}$and $\mathrm{Cu} 1000 \mu \mathrm{mol} \mathrm{L}^{-1}$, but there were no deaths when exposed to $\mathrm{Cu} 500 \mu \mathrm{mol} \mathrm{L}{ }^{-1}$. Plants that received $70 / 30$ of $\mathrm{NO}_{3}^{-} / \mathrm{NH}_{4}{ }^{+}$and $\mathrm{Cu} 500 \mu \mathrm{mol} \mathrm{L}^{-1}$ showed high $\mathrm{Cu}$ concentration in LR, high NR activity in LR, low $\mathrm{N}$ concentration in LR, low $\mathrm{N}$ accumulation in shoot, low number of leaves, low number of tillers and low shoot dry mass production in the second harvest. Disorders resulted from $\mathrm{Cu}$ toxicity in tanzania guineagrass are dependent on $\mathrm{NO}_{3}^{-} / \mathrm{NH}_{4}{ }^{+}$proportions and $\mathrm{Cu}$ rate in nutrient solution. The supply of $\mathrm{N}$ only as $\mathrm{NO}_{3}{ }^{-}$proved to be a strategy that ensures maintenance of the grass in an environment with high $\mathrm{Cu}$ concentration in nutrient solution, while the supply of $\mathrm{NO}_{3}{ }^{-}$with $\mathrm{NH}_{4}{ }^{+}$is strategic to increase $\mathrm{Cu}$ concentration in the biomass, in a growth medium with moderate $\mathrm{Cu}$ toxicity.

Keywords: Copper toxicity; Glutamine synthetase; Mineral nutrition of forage grasses; Nitrate reductase; Nitrogen fertilization; SPAD value

\subsection{Introdução}

O nitrogênio $(\mathrm{N})$ é o nutriente absorvido em maior quantidade pelas gramíneas forrageiras, sendo o principal modulador da produção de massa seca dessas plantas. A modulação do crescimento ocorre pelo fato do $\mathrm{N}$ participar da biossíntese de todos os aminoácidos e proteínas, além de compor as bases nitrogenadas, membranas e hormônios vegetais (Heldt, 2004). Dessa forma, o suprimento das plantas com formas de $\mathrm{N}$ é relatado por acelerar o metabolismo e consequentemente o crescimento vegetativo de plantas, confirmado para os aspectos produtivos e nutricionais do Panicum maximum cv. Aruana (Santos et al., 2013). Também foi confirmado que o suprimento com N, pela combinação de nitrato com amônio $\left(\mathrm{NO}_{3}{ }^{-} / \mathrm{NH}_{4}{ }^{+}\right)$, em relação ao suprimento de $\mathrm{N}$ na forma de $\mathrm{NO}_{3}{ }^{-}$, favorece o crescimento de Panicum maximum cv. Aruana (Santos et al., 2013). Portanto, dependendo da forma iônica de N a que são submetidas as plantas, há diferenças nutricionais e produtivas significativas.

As plantas absorvem $\mathrm{N}$ nas formas iônicas de $\mathrm{NO}_{3}{ }^{-}$e $\mathrm{NH}_{4}{ }^{+}$. A absorção de $\mathrm{N}$ na forma de $\mathrm{NO}_{3}{ }^{-}$é preferencial, sendo que o transporte desse íon até as células ocorre por meio de transportadores ativos de $\mathrm{NO}_{3}{ }^{-}$, localizados na membrana celular, que utilizam o gradiente de prótons transmembrana como fonte de energia (Heldt, 2004; Wang et al., 2012). A absorção do íon $\mathrm{NH}_{4}{ }^{+}$é não preferencial, pois em concentrações elevadas no citoplasma se transforma em $\mathrm{NH}_{3}$ e dissipa o gradiente de prótons transmembrana (Heldt, 2004). Por isso plantas em geral não transportam elevadas quantidades do íon $\mathrm{NH}_{4}{ }^{+}$nos vasos condutores, pelos seus transportadores ativos localizados na membrana celular, que também utilizam o gradiente de prótons transmembrana como energia metabólica (Wacker et al., 2014). De forma contrária, o íon $\mathrm{NO}_{3}{ }^{-}$é transportado normalmente das raízes para a parte aérea (Wang et al., 2012), mas há situações em que esse fluxo é alterado, como nos casos de estresse abiótico. Em situação de toxidez por metal, uma forma de estresse abiótico, o transporte normal de $\mathrm{NO}_{3}{ }^{-}$entre as partes da planta pode ser alterado de modo a favorecer órgãos como as raízes, parte da planta diretamente afetada pela presença do metal contaminante (Zhang et al., 2014a).

Após ser absorvido e transportado através da membrana celular, o $\mathrm{NO}_{3}{ }^{-}$é reduzido a nitrito $\left(\mathrm{NO}_{2}{ }^{-}\right)$pela ação da enzima nitrato redutase (NR) e em seguida a $\mathrm{NH}_{4}{ }^{+}$pela ação da nitrito redutase. Consequentemente, $\mathrm{o} \mathrm{NH}_{4}{ }^{+}$ é rapidamente incorporado em esqueletos de carbono provenientes do Ciclo de Calvin, dando origem ao glutamato, primeiro aminoácido sintetizado na planta (Xiong et al., 2006). A assimilação do $\mathrm{NH}_{4}{ }^{+}$na forma de glutamato é promovida primeiramente pela catalise da enzima glutamina sintetase (GS) + ATP, dando origem à glutamina. 
Depois, sob ação da glutamato sintase (GOGAT) + ferredoxina reduzida, são produzidas duas moléculas de glutamato, a partir da incorporação do $\mathrm{NH}_{4}{ }^{+}$em $\alpha$-cetoglutarato (Heldt, 2005; Thomsen et al., 2014). Sabe-se que o suprimento direto de $\mathrm{NH}_{4}{ }^{+}$em pequenas proporções pode ser benéfico, devido esse íon ser diretamente deslocado para a biossíntese de glutamato pela via metabólica GS/GOGAT, não precisando de investimento energético para a redução do $\mathrm{NO}_{3}{ }^{-}$a NH${ }^{+}$(Heldt, 2004; Epstein e Bloom, 2006).

Para o P. maximum cv. Aruana foi concluída como ideal a proporção das formas iônicas de $\mathrm{N}$ variando entre 70/30 e 55/45 de $\mathrm{NO}_{3}{ }^{-} / \mathrm{NH}_{4}{ }^{+}$, respectivamente, as quais proporcionaram maior área foliar, maior produção de massa seca da parte aérea e de raízes e maior eficiência de uso do N, em cultivo de casa de vegetação com solução nutritiva contendo $\mathrm{N}$ de $15 \mathrm{mmol} \mathrm{L}-1$ (Santos et al., 2013). O efeito positivo de doses moderadas de $\mathrm{NH}_{4}^{+}$, em substituição a parte de $\mathrm{NO}_{3}{ }^{-}$, pode ser explicado pelo fato da assimilação do $\mathrm{N}$ na forma de $\mathrm{NO}_{3}{ }^{-}$requerer aproximadamente duas vezes mais ATP quando comparada à assimilação direta pelo $\mathrm{NH}_{4}{ }^{+}$(Epstein e Bloom, 2006). Dessa forma, em situação de plantas expostas ao estresse abiótico, como no caso de excesso de Cu no meio de cultivo, as proporções de $\mathrm{NO}_{3}{ }^{-} / \mathrm{NH}_{4}{ }^{+}$nas quais o capim tanzânia cresceu inicialmente podem favorecer a nutrição da planta de modo a possibilitar menor desordem nutricional, permitindo assim o crescimento da planta no ambiente tóxico.

Uma das causas da toxidez por Cu em plantas é seu impacto negativo nas atividades das enzimas NR e GS, responsáveis pela assimilação de N. O Cu afeta a aquisição de $\mathrm{N}$ pela planta e consequentemente restringe sua persistência no meio de cultivo contaminado. As desordens causadas pelo excesso de $\mathrm{Cu}$ refletem em menor assimilação do $\mathrm{N}$ e menor crescimento, quando comparadas às plantas crescidas em ambientes sem excesso de $\mathrm{Cu}$ (Xiong et al., 2006; Zhang et al., 2014b). Apesar desse conhecimento sobre as desordens causadas pelo excesso de $\mathrm{Cu}$ no metabolismo assimilatório de $\mathrm{N}$ das plantas modelos e outras espécies de relevância econômica, não há relatos similares para as gramíneas forrageiras tropicais como o P. maximum cv. Tanzânia, especialmente os que buscam propor alternativas de alívio da toxidez por $\mathrm{Cu}$ a partir da associação com proporções de $\mathrm{NO}_{3}{ }^{-} / \mathrm{NH}_{4}{ }^{+}$.

O capim Panicum maximum cv. Mombaça crescido em casa de vegetação com doses de $\mathrm{N}$ que variaram de 22 até $462 \mathrm{mg} \mathrm{L}^{-1}$, em solução nutritiva, na mais alta dose de $\mathrm{N}$ apresentou maior atividade da $\mathrm{NR}$ e maior valor SPAD (determinação indireta da clorofila) nas lâminas diagnósticas do capim, que alinhou-se ao aumento da concentração de $\mathrm{N}$ total e da produção do capim (Lavres Junior et al., 2010). Isso mostra que a atividade da NR, a concentração de $\mathrm{N}$ total e a produção de clorofila é otimizada a partir do suprimento com $\mathrm{N}$, mas não há relatos mostrando esses efeitos em função do suprimento do $\mathrm{N}$ com proporções de $\mathrm{NO}_{3}{ }^{-} / \mathrm{NH}_{4}{ }^{+}$para o capim tanzânia exposto ao excesso de $\mathrm{Cu}$. A ausência de resultados nesse sentido pode limitar o desenvolvimento de programas de fitorremediação utilizando essa espécie, uma vez que metais como o $\mathrm{Cu}$ alteram a concentração de clorofila, a atividade das enzimas NR e GS e a concentração e acúmulo de $\mathrm{NO}_{3}{ }^{-}, \mathrm{NH}_{4}{ }^{+}$e $\mathrm{N}$ total (Weber et al., 1991; Zhang et al., 2014b). No entanto, as atuais pesquisas com Panicum maximum cv. Tanzânia ainda não avançaram no sentido de elucidar os impactos do $\mathrm{Cu}$ nas enzimas de assimilação de N, na nutrição mineral e na produção dessas plantas, mesmo quando associado a proporções de $\mathrm{NO}_{3}{ }^{-} / \mathrm{NH}_{4}{ }^{+}$como ferramenta nutricional de alívio de toxidez por metal.

Para o capim tanzânia, acredita-se que a energia economizada em função do suprimento de $\mathrm{N}$ na forma combinada de $\mathrm{NO}_{3}^{-}$e $\mathrm{NH}_{4}{ }^{+}$, em relação ao suprimento exclusivo com $\mathrm{NO}_{3}{ }^{-}$, pode servir para incrementar a absorção de minerais pelas raízes (Santos et al., 2013). Esse efeito é desejável em programas de fitorremediação de metais, pois dessa forma é possível modular o transporte e a concentração do excesso de Cu na parte aérea e as raízes do capim, até o limite de concentração de $\mathrm{Cu}$ definido pela sua genética, a qual indica a severa toxidez por metal. No entanto, os reflexos na absorção dos íons $\mathrm{NO}_{3}{ }^{-}$e $\mathrm{NH}_{4}{ }^{+}$e os impactos no crescimento e produção do 
capim tanzânia em condições de toxidez por $\mathrm{Cu}$ são desconhecidos, assim como nas demais plantas de relevância econômica. Nesse sentido, é importante testar a hipótese que proporções de $\mathrm{NO}_{3}{ }^{-} / \mathrm{NH}_{4}{ }^{+}$alteram a homeostase nutricional e com isso a permanência do capim tanzânia no meio de cultivo contaminado, possivelmente envolvendo mecanismos de ação pouco elucidados (Chen e Kao, 1998; Hamlin e Barker, 2006; Zhang et al., 2014a). Estudos atuais alinham-se na confirmação da hipótese, além do que as recentes descobertas para o capim tanzânia mostram que o fornecimento de nutrientes pode alterar a tolerância do capim aos metais, assim como seu crescimento no ambiente contaminado (Gilabel et al., 2014; Rabêlo et al., 2016).

O objetivo foi avaliar as desordens causadas pela toxidez de $\mathrm{Cu}$ nos atributos nutricionais, morfológicos e produtivos do capim tanzânia e o papel das proporções de $\mathrm{NO}_{3}{ }^{-} / \mathrm{NH}_{4}{ }^{+}$no alívio dessa toxidez.

\subsection{Material e Métodos}

\subsubsection{Condições experimentais}

O capim tanzânia foi cultivado em casa de vegetação com sistema de ventilação/exaustão que permite controle da troca gasosa automaticamente, mantendo a temperatura abaixo de $33{ }^{\circ} \mathrm{C}$. As mudas foram obtidas a partir de sementes, que foram germinadas e inicialmente crescidas em bandejas contendo areia lavada com água desionizada. Quinze plântulas (4-5 cm de altura) foram transplantadas para cada unidade experimental com 3,5 L de volume, contendo quartzo moído (sílica) como substrato. O delineamento experimental foi de blocos completos ao acaso, constituindo-se o experimento de um fatorial $4 \times 3 \mathrm{com}$ seis repetições, sendo três destinadas às avaliações produtivas e três às avaliações metabólicas. Os fatores empregados no experimento foram três proporções de $\mathrm{NO}_{3}{ }^{-} / \mathrm{NH}_{4}{ }^{+}(100 / 0,70 / 30,50 / 50)$ combinadas com quatro doses de $\mathrm{Cu}(0,3 ; 250 ; 500$ e $1000 \mu \mathrm{mol} \mathrm{L}-1)$.

Por sete dias após o transplantio das mudas foi utilizada a solução nutritiva de Hoagland e Arnon (1950), contendo as proporções de $\mathrm{NO}_{3}{ }^{-} / \mathrm{NH}_{4}{ }^{+}$, dose de $\mathrm{N}$ de $15 \mathrm{mmol} \mathrm{L}{ }^{-1}$ e diluída a $20 \%$ da força iônica. O desbaste das mudas foi realizado durante cinco dias até restarem cinco plantas em cada vaso. Após os sete dias iniciais, foi aplicada solução com $100 \%$ da força iônica, mantendo as proporções de $\mathrm{NO}_{3}{ }^{-} / \mathrm{NH}_{4}{ }^{+}$estudadas, dose de $\mathrm{N}$ de 15 mmol L-1 e $\mathrm{Cu}$ de $0,3 \mu \mathrm{mol} \mathrm{L}{ }^{-1}$ (ambas indicadas na solução de Hoagland e Arnon, 1950). Com 21 dias de crescimento na solução contendo $100 \%$ da força iônica, as plantas foram expostas às demais doses de Cu de 250,500 e $1000 \mu \mathrm{mol} \mathrm{L}{ }^{-1}$. A solução nutritiva foi circulada diariamente (seis vezes ao dia no início do crescimento e três vezes nas demais etapas), completando diariamente com água desionizada o volume evapotranspirado até 1,5 L, capacidade máxima do volume de solução de cada unidade experimental. A renovação da solução foi realizada semanalmente, para evitar que o $\mathrm{NH}_{4}{ }^{+}$fosse oxidado a $\mathrm{NO}_{3}{ }^{-}$, mantendo assim as proporções de $\mathrm{NO}_{3}{ }^{-} / \mathrm{NH}_{4}{ }^{+}$estabelecidas.

Foram avaliados dois cortes das plantas, o primeiro realizado a $5 \mathrm{~cm}$ do substrato e o segundo corte rente ao substrato. O primeiro corte foi efetuado com 35 dias de crescimento das plantas e sete dias de exposição às doses de $\mathrm{Cu}$, balizada pela ocorrência de toxidez severa causada pela dose de $\mathrm{Cu}$ de $1000 \mu \mathrm{mol} \mathrm{L}{ }^{-1}$. Após o corte das plantas a solução foi renovada, mantendo-se as proporções de $\mathrm{NO}_{3}{ }^{-} / \mathrm{NH}_{4}{ }^{+}$e a dose de $\mathrm{Cu}$ de $0,3 \mu \mathrm{mol} \mathrm{\textrm {L } ^ { - 1 }}$. O segundo corte ocorreu aos 21 dias de rebrotação das plantas, sem reaplicação das doses tóxicas do metal, uma vez que na primeira exposição a toxidez por $\mathrm{Cu}$ foi severa e uma nova aplicação desse metal poderia provocar morte generalizada de plantas e inviabilizar a coleta de amostras. Assim, o efeito do $\mathrm{Cu}$ no segundo corte do capim foi devido ao cobre residual aplicado na fase final do primeiro crescimento. 
Por ocasião dos cortes, a parte aérea foi separada em lâminas de folhas recém-expandidas ou diagnósticas (LR) e demais componentes da parte aérea. As raízes foram coletadas imediatamente após o segundo corte. Para as avaliações produtivas e de acúmulo de minerais, as partes das plantas foram secas em estufa de circulação forçada a $65{ }^{\circ} \mathrm{C}$ por 72 horas e posteriormente trituradas em moinho tipo Wiley. Para a avaliação da atividade da glutamina sintetase (GS), as LR das plantas destinadas às avaliações metabólicas foram rapidamente separadas, acondicionadas em papel alumínio, imediatamente congeladas em $\mathrm{N}$ líquido, seguida de armazenagem em "freezer" $-80{ }^{\circ} \mathrm{C}$ e posterior moagem criogênica em recipiente adequado à utilização de $\mathrm{N}$ líquido.

\subsubsection{Observação visual das plantas}

No decorrer do experimento foi observado o aspecto visual das plantas em função das proporções de $\mathrm{NO}_{3}{ }^{-} / \mathrm{NH}_{4}{ }^{+}$, o aparecimento de sintomas visuais decorrentes da exposição às doses tóxicas de Cu (padrão da necrose e clorose) e manifestações visuais de alívio de toxidez de Cu pelas proporções de $\mathrm{NO}_{3}{ }^{-} / \mathrm{NH}_{4}{ }^{+}$.

\subsubsection{Determinações de $\mathrm{Cu}, \mathrm{NO}_{3}{ }^{-}, \mathrm{NH}_{4}{ }^{+}$e $\mathrm{N}_{\text {total }}$ em tecido vegetal}

A concentração de $\mathrm{Cu}$ foi determinada nas partes da planta segundo metodologia de Sarruge e Haag (1974), após digestão nítrico-perclórica e leitura no extrato por espectrofotometria de absorção atômica. O N $\mathrm{N}_{\text {total }}$ foi obtido a partir da digestão sulfúrica pelo método de Kjeldahl, com quantificação do nutriente por titulação com solução diluída de $\mathrm{H}_{2} \mathrm{SO}_{4}$ (Sarruge e Haag, 1974). Os íons $\mathrm{NO}_{3}{ }^{-}$e $\mathrm{NH}_{4}{ }^{+}$nas partes da planta foram determinados de acordo com Tedesco et al. (1985), utilizando solução extratora de $\mathrm{KCl}\left(1 \mathrm{~mol} \mathrm{~L}^{-1}\right)$. Para o $\mathrm{NH}_{4}^{+}$o extrato foi destilado com óxido de magnésio calcinado $(\mathrm{MgO})$ e coletado em ácido bórico e indicadores, para ser titulado com solução de $\mathrm{H}_{2} \mathrm{SO}_{4}\left(0,005 \mathrm{~mol} \mathrm{~L}^{-1}\right)$. No mesmo extrato, determinou-se o $\mathrm{NO}_{3}{ }^{-}$por destilação após emprego da Liga de Devarda e titulação com $\mathrm{H}_{2} \mathrm{SO}_{4}\left(0,005 \mathrm{~mol} \mathrm{~L}^{-1}\right)$. Os acúmulos de $\mathrm{NO}_{3}{ }^{-}, \mathrm{NH}_{4}{ }^{+}$e $\mathrm{N}_{\text {total }}$ nas partes da planta foram obtidos a partir do produto da concentração dos elementos nas partes da planta pelas respectivas massas secas produzidas.

\subsubsection{Atividade de enzimas de assimilação do nitrogênio}

Pelo fato da atividade da enzima nitrato redutase (NR, EC. 1.6.6.1) nas folhas ser induzida pela luz, a coleta das folhas diagnósticas foi executada após a aclimatação das unidades experimentais na câmara de crescimento por $24 \mathrm{~h}$, para evitar variações na atividade da enzima causadas pelas variações na emissão da luz solar. A temperatura da câmara foi mantida constante em $27^{\circ} \mathrm{C}$ e a luminosidade em PAR $400 \mu \mathrm{mol} \mathrm{m}^{-2} \mathrm{~s}^{-1}$. A determinação da atividade da NR foi executada de acordo com a metodologia de Mulder et al. (1969), que baseou-se na produção de $\mathrm{NO}_{2}^{-}$a partir do $\mathrm{NO}_{3}{ }^{-}$fornecido durante a incubação com cortes finos de $\mathrm{LR}$ in vitro a $35{ }^{\circ} \mathrm{C}$ por 2 horas. A incubação foi feita em solução contendo tampão fosfato de potássio (pH 7,5) e nitrato de potássio $\left(0,25 \mathrm{~mol} \mathrm{~L}^{-1}\right)$. A atividade da enzima NR foi cessada com a utilização de solução de sulfanilamida $\left(58 \mathrm{mmol} \mathrm{L}^{-1}\right)$, com posterior aplicação de $\mathrm{N}$-(1-Naftil) etilenodiamina dicloridrato (NED, $\left.0,77 \mathrm{mmol} \mathrm{L}{ }^{-1}\right)$ e acetato $\left(2 \mathrm{~mol} \mathrm{~L}^{-1}\right)$ para 
desenvolvimento de cor. A leitura foi feita espectrofotômetro a 540 ๆm com estimativa dos valores a partir de curva padrão de $\mathrm{NO}_{2}^{-}$.

A atividade da enzima glutamina sintetase (GS, EC. 6.3.1.2) foi analisada a partir da metodologia de Elliott (1952) nas LR do capim tanzânia. As LR frescas e congeladas do capim foram maceradas com solução extratora tris$\mathrm{HCl}\left(50 \mathrm{mmol} \mathrm{L}^{-1}\right)$, mercaptoetanol $\left(2 \mathrm{mmol} \mathrm{L}^{-1}\right)$ e ácido etilenodiamino tetra-acético (EDTA, $\left.1 \mathrm{mmol} \mathrm{L}-1\right)$, sendo os extratos centrifugados a $10.000 \mathrm{rpm}$ a $4{ }^{\circ} \mathrm{C}$ por $10 \mathrm{~min}$. Após, os extratos foram incubados em tubos de ensaio por $30 \mathrm{~min}$ a $30^{\circ} \mathrm{C}$ em meio contendo TRIS- $\mathrm{HCl}\left(200 \mathrm{mmol} \mathrm{L}^{-1}\right)$, ATP $(50 \mathrm{mmol} \mathrm{L}-1)$, ácido glutâmico $\left(500 \mathrm{mmol} \mathrm{L}^{-1}\right)$, sulfato de magnésio (1 mol L-1), hidroxilamina $\left(100 \mathrm{mmol} \mathrm{L}^{-1}\right)$ e cisteína $\left(100 \mathrm{mmol} \mathrm{L}^{-1}\right)$. Após 30 minutos de incubação, a atividade foi cessada com aplicação de solução contendo cloreto de ferro $(616$ mmol L-1), TCA $(1,45$ mol L-1) e $\mathrm{HCl}\left(1 \mathrm{~mol} \mathrm{~L}^{-1}\right)$. A precipitação do excesso de proteína foi realizada a partir da centrifugação a $5000 \mathrm{rpm}$ por 5 minutos, com leitura no sobrenadante em espectrofotômetro a $540 \eta \mathrm{m}$. A estimativa dos valores de atividade foram realizados a partir de curva padrão de $\gamma$-glutamil hidroxamato.

\subsubsection{Quantificação do valor SPAD}

A determinação indireta da clorofila (unidade SPAD) foi realizada no capim tanzânia um dia antes dos cortes, pela obtenção de leituras coletadas com o auxílio do aparelho SPAD 502 MINOLTA em cada unidade experimental. A medida foi composta pela média de dez leituras realizadas no terço médio das LR de cada planta, excluindo-se a bordadura e nervura central das LR (Lavres Junior et al., 2010).

\subsubsection{Morfogênese e produção de massa seca}

As plantas tiveram as folhas e perfilhos contados imediatamente antes dos cortes. Inicialmente estava previsto que as lâminas foliares seriam passadas no aparelho LI-3000 para quantificação da área foliar. No entanto, a toxidez por $\mathrm{Cu}$ promoveu o enrolamento excessivo das folhas (Figura 1) e por isso este atributo não foi quantificado, uma vez que os valores seriam subestimados. No material vegetal seco, com o auxilio de balança digital de precisão, foi determinada a produção de massa seca das partes da planta. Para determinação da superfície radicular, as raízes frescas de uma planta foram separadas e tingidas em solução de violeta genciana $50 \mathrm{mg} \mathrm{L}^{-1}$. Depois de coradas e secas as raízes foram scaneadas e transformadas em arquivo digital, de modo que a superfície pudesse ser quantificada com o emprego do software SAFIRA (Costa et al., 2014), desenvolvido pela Embrapa (Empresa Brasileira de Pesquisa Agropecuária).

\subsubsection{Análise estatística}

A análise estatística dos resultados foi realizada utilizando o software "Statistical Analysis System" (SAS Intitute, 2008). Quando o teste $\mathrm{F}$ foi significativo para a interação proporções de $\mathrm{NO}_{3}{ }^{-} / \mathrm{NH}_{4}{ }^{+} \times$doses de $\mathrm{Cu}$ efetuou-se o desdobramento e comparação de médias para as proporções de $\mathrm{NO}_{3}{ }^{-} / \mathrm{NH}_{4}{ }^{+}$dentro de cada dose de $\mathrm{Cu}$ e para as doses de $\mathrm{Cu}$ dentro de cada proporção de $\mathrm{NO}_{3}{ }^{-} / \mathrm{NH}_{4}{ }^{+}$. No caso da interação não ser significativa e o teste F mostrar significância para os fatores isolados, foi procedida análise de regressão para as doses de Cu e/ou 
comparações de médias para as proporções de $\mathrm{NO}_{3}{ }^{-} / \mathrm{NH}_{4}{ }^{+}$. Para comparação de médias foi escolhido o teste de Tukey a 5\%. Quando a dose mais tóxica de Cu de $1000 \mu \mathrm{mol} \mathrm{L}-1$ impossibilitou a rebrotação, conduzindo as plantas à perda das respectivas parcelas experimentais, a análise de variância foi executada com o emprego de fatorial $3 \times 3$. Os resultados que não apresentaram distribuição foram normalizados pelas transformações $\sqrt{x}$ ou $\log x$.

\subsection{Resultados}

\subsubsection{Primeiro corte}

\subsubsection{Sintomas visuais das plantas}

$\mathrm{O}$ efeito das proporções de $\mathrm{NO}_{3}{ }^{-} / \mathrm{NH}_{4}{ }^{+}$no crescimento inicial das plantas resultou em modificações visuais, principalmente no porte e estabelecimento do capim, pois as plantas cultivadas com $70 / 30$ de $\mathrm{NO}_{3}{ }^{-} / \mathrm{NH}_{4}{ }^{+}$ se estabeleceram mais firmemente no substrato em comparação ao capim nutrido com 100\% do N na forma de $\mathrm{NO}_{3}{ }^{-}$. Inicialmente, boa parte plantas supridas com $100 \%$ do $\mathrm{N}$ na forma de $\mathrm{NO}_{3}{ }^{-}$apresentaram princípio de

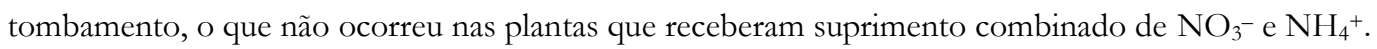

A aplicação da dose de $\mathrm{Cu}$ de 500 e principalmente de $1000 \mu \mathrm{mol} \mathrm{L}^{-1}$ na solução nutritiva promoveram respostas visuais destacadas nas plantas, haja visto que aquelas supridas com 70/30 de $\mathrm{NO}_{3}^{-} / \mathrm{NH}_{4}{ }^{+}$passaram a apresentar sintomas de toxidez por $\mathrm{Cu}$, os quais foram agravados ao longo dos sete dias de exposição ao metal (Figura 1a). Plantas tratadas exclusivamente com $\mathrm{NO}_{3}{ }^{-}$não apresentaram ou somente exibiram sintomas leves de toxidez (Figura 1b). Os principais sintomas de toxidez se caracterizaram pelo enrolamento das lâminas foliares em torno da nervura central (Figura 2) e progressiva mudança da cor verde para a cor amarela (Figura 1).
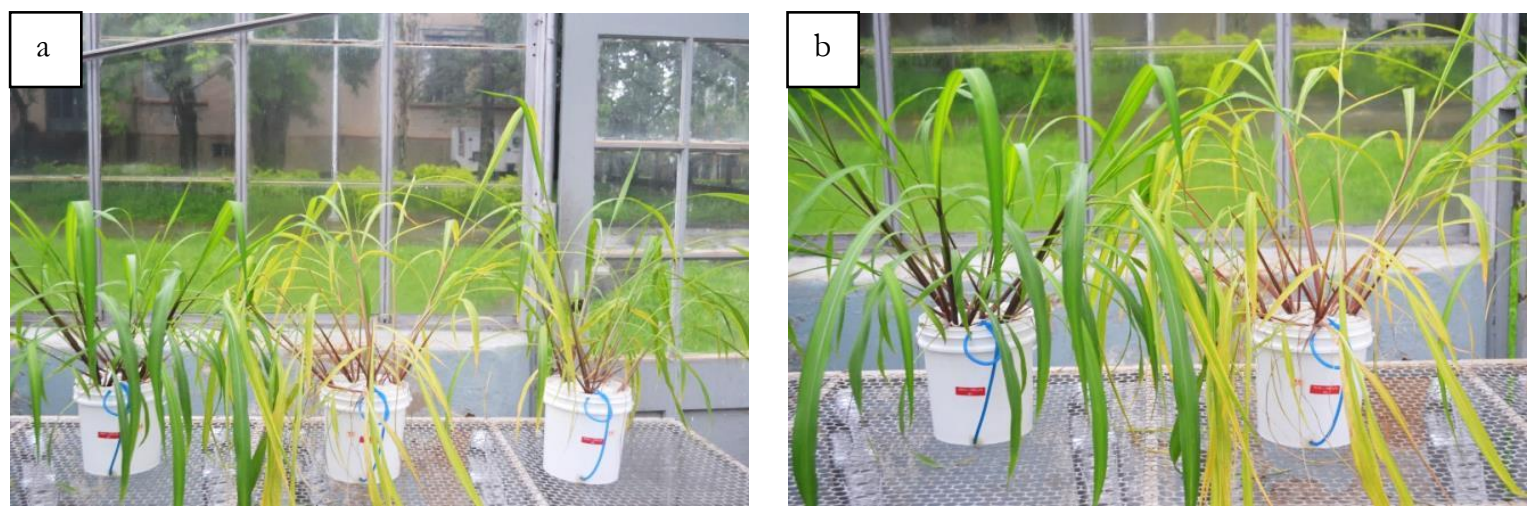

Figura 1. Sintomas visuais de toxidez por $\mathrm{Cu}$ de $1000 \mu \mathrm{mol} \mathrm{L} \mathrm{L}^{-1}$ nas proporções 100/0, 70/30 e 50/50 de $\mathrm{NO}_{3}{ }^{-} / \mathrm{NH}_{4}{ }^{+}(\mathrm{a}$, esquerda para direita) e maior detalhamento das proporções 100/0 e 70/30 de $\mathrm{NO}_{3}-/ \mathrm{NH}_{4}{ }^{+}$(b, esquerda para direita). Destaca-se a leve ou nula toxidez nas plantas da esquerda, sendo as demais apresentando toxidez severa, após sete dias de exposição ao Cu. 


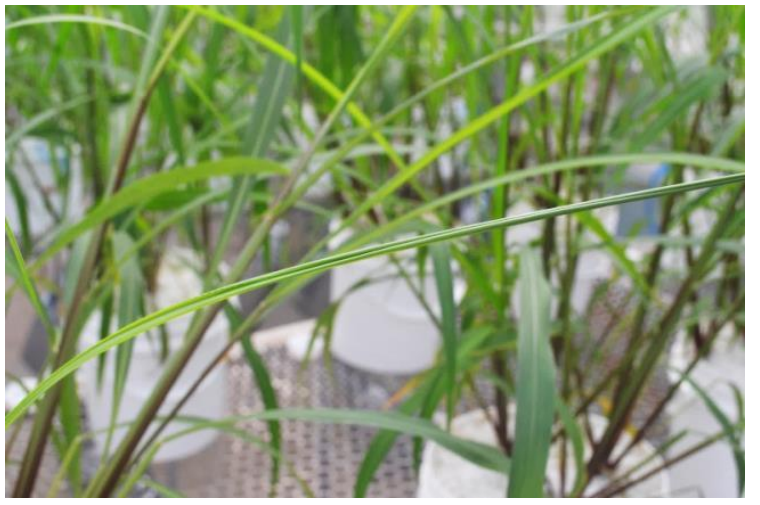

Figura 2. Enrolamento de folhas de capim tanzânia induzidos pela toxidez por $\mathrm{Cu}$, que inviabilizou a quantificação da área foliar.

Inicialmente, com dois dias de exposição ao $\mathrm{Cu}$, a toxidez se manifestou com o enrolamento temporário das bordas das folhas (Figura 3a). Nos primeiros dias de exposição do capim tanzânia ao Cu na solução nutritiva, o efeito visual de murchamento das plantas nas plantas afetadas pelo metal foi mais visível nos momentos com temperaturas mais elevadas, retomando a turgidez conforme a diminuição da temperatura do ar. Após cinco dias de exposição ao $\mathrm{Cu}$ em solução nutritiva, nos casos em que ocorreram toxidez severa, as folhas se enrolaram e murcharam permanentemente (Figura 3b). O segundo principal sintoma visual de toxidez de Cu foi a clorose das plantas, caracterizada pela mudança da intensidade do verde das folhas para verde claro e pálido, seguindo para a cor amarela (Figura 3c) e finalizando com tom laranja/vermelho, na forma de estrias foliares (Figura 3d). A necrose do tecido ocorreu de forma tímida, nas pontas das folhas (Figura 3c), ao final do processo de enrolamento e perda do teor de clorofila.
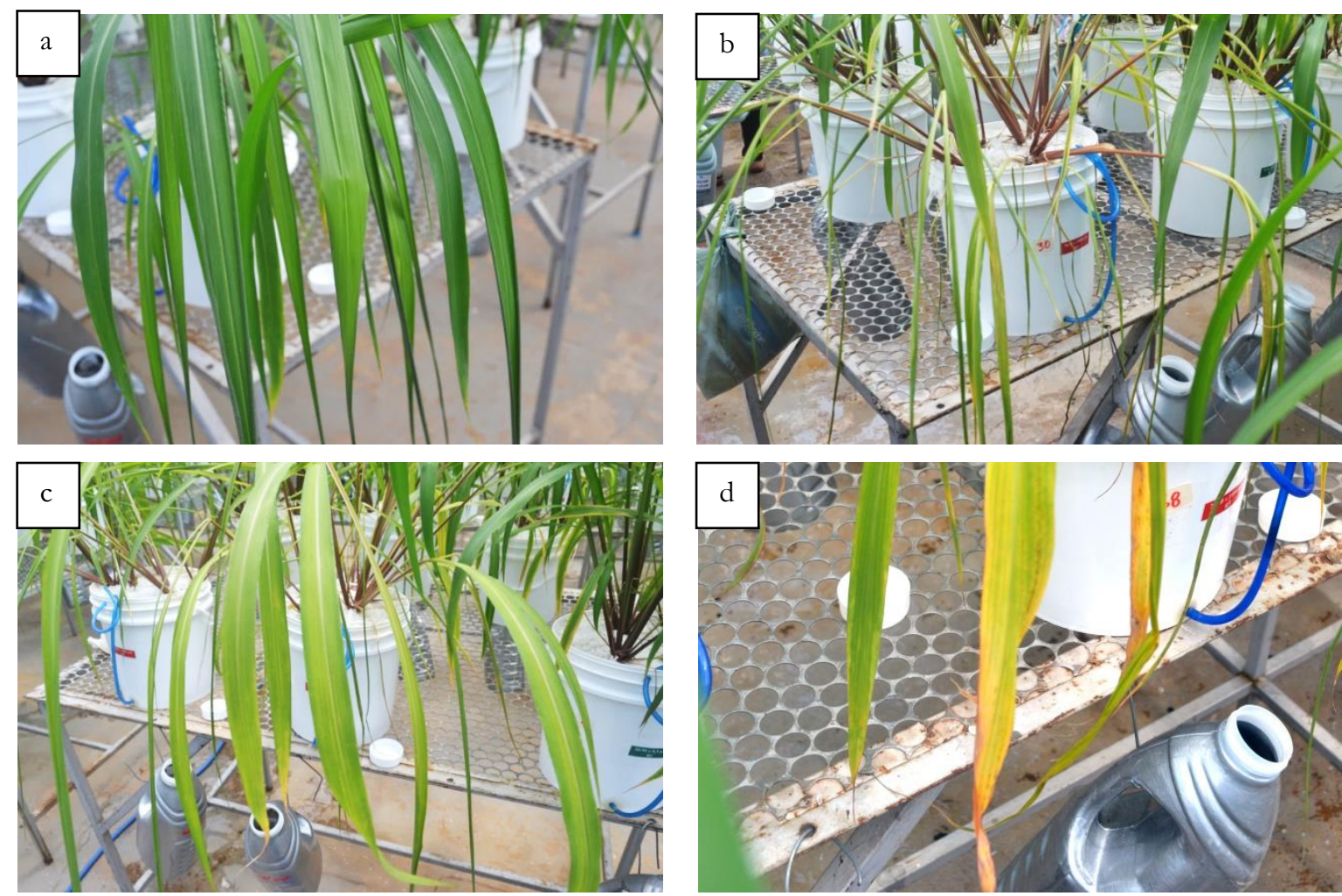

Figura 3. Sintomas visuais nas proporções $70 / 30$ (a, b, c) e 50/50 de $\mathrm{NO}_{3}^{-} / \mathrm{NH}_{4}{ }^{+}$(d) em capim tanzânia, após dois (a) e cinco dias (a, b, c) de exposição a dose de Cu de $1000 \mu \mathrm{mol} \mathrm{L}^{-1}$. 


\subsubsection{Concentração e acúmulo de minerais na parte aérea da planta}

As análises estatísticas mostraram que a interação proporções de $\mathrm{NO}_{3}{ }^{-} / \mathrm{NH}_{4}{ }^{+} \times$dose de $\mathrm{Cu}$ foi significativa para a concentração de $\mathrm{Cu}$ nas LR do capim tanzânia (Figura 4). A maior concentração de Cu nas LR das plantas ocorreu na proporção 70/30 de $\mathrm{NO}_{3}{ }^{-} / \mathrm{NH}_{4}{ }^{+}$combinada a dose de $\mathrm{Cu}$ de $1000 \mu \mathrm{mol} \mathrm{L}{ }^{-1}$, que aumenta de 1,4 a $428 \mathrm{mg} \mathrm{kg}^{-1}$ da dose de Cu de 0,3 a $1000 \mu \mathrm{mol} \mathrm{L}-1$, respectivamente (Figura 4). Nas plantas supridas com 100\% do $\mathrm{N}$ na forma de $\mathrm{NO}_{3}{ }^{-}$a concentração de $\mathrm{Cu}$ nas $\mathrm{LR}$, sob doses de $\mathrm{Cu}$ de 250, 500 e $1000 \mu \mathrm{mol} \mathrm{L}{ }^{-1}$ foram iguais e maiores que as constatadas na dose de $\mathrm{Cu}$ de $0,3 \mu \mathrm{mol} \mathrm{L}-1$ (Figura 4). As plantas supridas com proporção de 50/50 de $\mathrm{NO}_{3}{ }^{-} / \mathrm{NH}_{4}{ }^{+}$expostas às doses de $\mathrm{Cu}$ de 250,500 e $1000 \mu \mathrm{mol} \mathrm{L}-1$ apresentaram valores de concentração de $\mathrm{Cu}$ menores que os verificados na proporção $70 / 30$ de $\mathrm{NO}_{3}{ }^{-} / \mathrm{NH}_{4}{ }^{+}$e maiores que os constatados na proporção 100/0 de $\mathrm{NO}_{3}{ }^{-} / \mathrm{NH}_{4}{ }^{+}$(Figura 4).

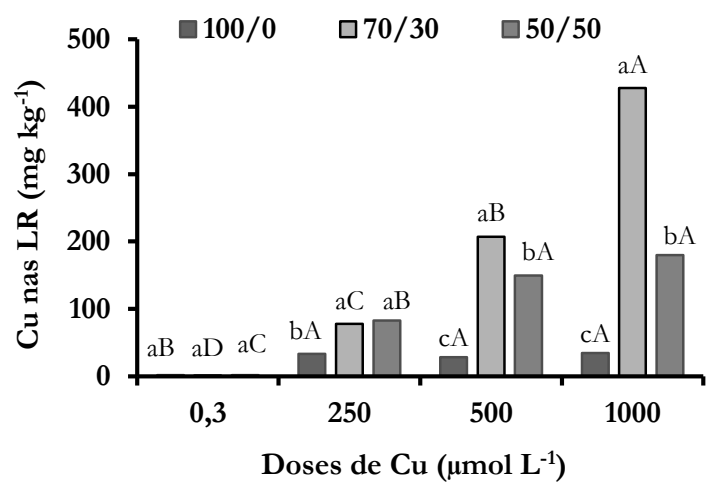

Figura 4. Concentração de $\mathrm{Cu}$ nas lâminas diagnósticas (LR) do capim tanzânia no primeiro corte, em função de doses de Cu e proporções de $\mathrm{NO}_{3}-\mathrm{NH}_{4}{ }^{+}$em solução nutritiva. Letras minúsculas distintas mostram diferença significativa pelo teste de Tukey entre proporções de $\mathrm{NO}_{3}{ }^{-} / \mathrm{NH}_{4}{ }^{+}$dentro de cada dose de $\mathrm{Cu}$ e letras maiúsculas distintas entre as doses de Cu dentro de cada proporção de $\mathrm{NO}_{3}{ }^{-} \mathrm{NH}_{4}{ }^{+}$. Os resultados originais foram transformados em $\sqrt{x}$ para se ajustar a distribuição normal. Coeficiente de variação $(\%)=9,5$.

A interação proporções de $\mathrm{NO}_{3}{ }^{-} / \mathrm{NH}_{4}{ }^{+} \times$dose de $\mathrm{Cu}$ foi significativa para a concentração e acúmulo de $\mathrm{NH}_{4}{ }^{+}$nas LR e parte aérea, respectivamente (Figura 5). Foi verificado que as plantas supridas exclusivamente com $\mathrm{NO}_{3}{ }^{-}$e expostas a doses de $\mathrm{Cu}$ não apresentaram diferenças nas médias de concentração de $\mathrm{NH}_{4}{ }^{+}$nas LR. Esse resultado foi diferente do constatado nas plantas supridas com 70/30 e 50/50 de $\mathrm{NO}_{3}{ }^{-} / \mathrm{NH}_{4}{ }^{+}$, as quais apresentaram maiores concentrações de $\mathrm{NH}_{4}{ }^{+}$nas $\mathrm{LR}$, principalmente na dose de $\mathrm{Cu}$ de 500 e $1000 \mu \mathrm{mol} \mathrm{L}{ }^{-1}$, atingindo concentração de $\mathrm{NH}_{4}{ }^{+}$de até 4,6 $\mathrm{g} \mathrm{kg}^{-1}$ (Figura 5a). As doses de $\mathrm{Cu}$ influenciaram no maior acúmulo de $\mathrm{NH}_{4}^{+}$ apenas na proporção 70/30 de $\mathrm{NO}_{3}{ }^{-} / \mathrm{NH}_{4}{ }^{+}$combinada à dose de $\mathrm{Cu}$ de $1000 \mu \mathrm{mol} \mathrm{L}{ }^{-1}$, uma vez que nas demais proporções $\mathrm{NO}_{3}{ }^{-} / \mathrm{NH}_{4}{ }^{+}$não houve alteração do acúmulo em função das doses de $\mathrm{Cu}$ (Figura $5 \mathrm{~b}$ ). 

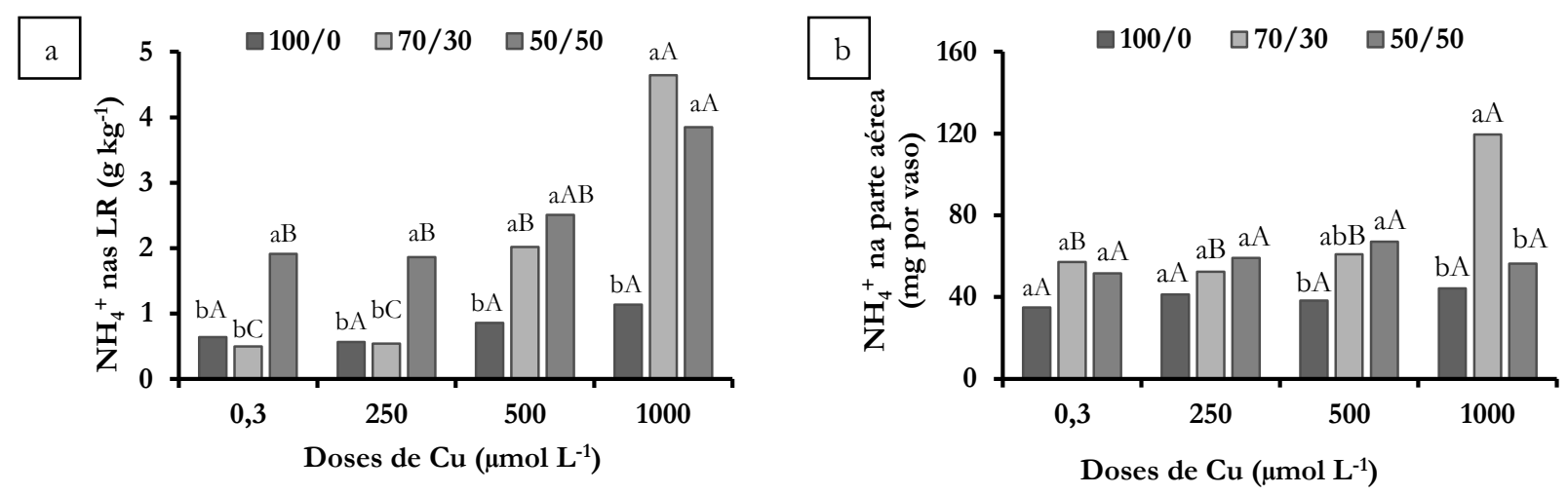

Figura 5. Concentração de $\mathrm{NH}_{4}{ }^{+}$nas lâminas diagnósticas (LR) (a) e acúmulo de $\mathrm{NH}_{4}{ }^{+}$na parte aérea (b) do capim tanzânia no primeiro corte em função de doses de $\mathrm{Cu}$ e proporções de $\mathrm{NO}_{3}-\mathrm{NH}_{4}{ }^{+}$em solução nutritiva. Letras minúsculas distintas mostram diferença significativa pelo teste de Tukey entre proporções de $\mathrm{NO}_{3}-\mathrm{NH}_{4}{ }^{+}$dentro de cada dose de $\mathrm{Cu}$ e letras maiúsculas distintas entre as doses de $\mathrm{Cu}$ dentro de cada proporção de $\mathrm{NO}_{3}{ }^{-} / \mathrm{NH}_{4}{ }^{+}$. Os resultados originais foram transformados em $\sqrt{x}$ para se ajustar a distribuição normal. Coeficiente de variação $(\%)=16,4$ (a) e 11,4 (b).

Constatou-se que a interação proporções de $\mathrm{NO}_{3}^{-} / \mathrm{NH}_{4}{ }^{+} \times$doses de $\mathrm{Cu}$ foi significativa para a concentração e acúmulo de $\mathrm{NO}_{3}{ }^{-}$nas LR e parte aérea, respectivamente (Figura 6). Notou-se que a concentração de $\mathrm{NO}_{3}{ }^{-}$foi maior nas LR do capim exposto as doses de $\mathrm{Cu}$ de 500 e $1000 \mu \mathrm{mol} \mathrm{L}{ }^{-1}$, crescido com $\mathrm{N}$ na forma de $\mathrm{NO}_{3}{ }^{-}$. $\mathrm{Na}$ dose de $\mathrm{Cu}$ de $500 \mu \mathrm{mol} \mathrm{L}{ }^{-1}$ o suprimento exclusivo com $\mathrm{NO}_{3}{ }^{-}$promoveu maior concentração dessa forma de $\mathrm{N}$ apenas na proporção 50/50 de $\mathrm{NO}_{3}{ }^{-} / \mathrm{NH}_{4}{ }^{+}$(Figura 6a). Quanto ao acúmulo de $\mathrm{NO}_{3}{ }^{-}$, constatou-se que doses de $\mathrm{Cu}$

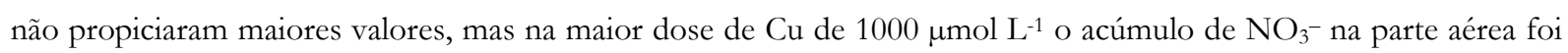
maior nas plantas supridas com $\mathrm{N}$ na forma de $\mathrm{NO}_{3}^{-}$e menor nas plantas supridas com 50/50 de $\mathrm{NO}_{3}^{-} / \mathrm{NH}_{4}{ }^{+}$ (Figura 6b). Quando expostas ao $\mathrm{Cu}$ de $250 \mu \mathrm{mol} \mathrm{L}{ }^{-1}$, as plantas supridas com $70 / 30 \mathrm{de} \mathrm{NO}_{3}{ }^{-} / \mathrm{NH}_{4}{ }^{+}$acumularam mais $\mathrm{NO}_{3}{ }^{-}$do que as plantas supridas com $50 / 50$ de $\mathrm{NO}_{3}{ }^{-} / \mathrm{NH}_{4}{ }^{+}$.
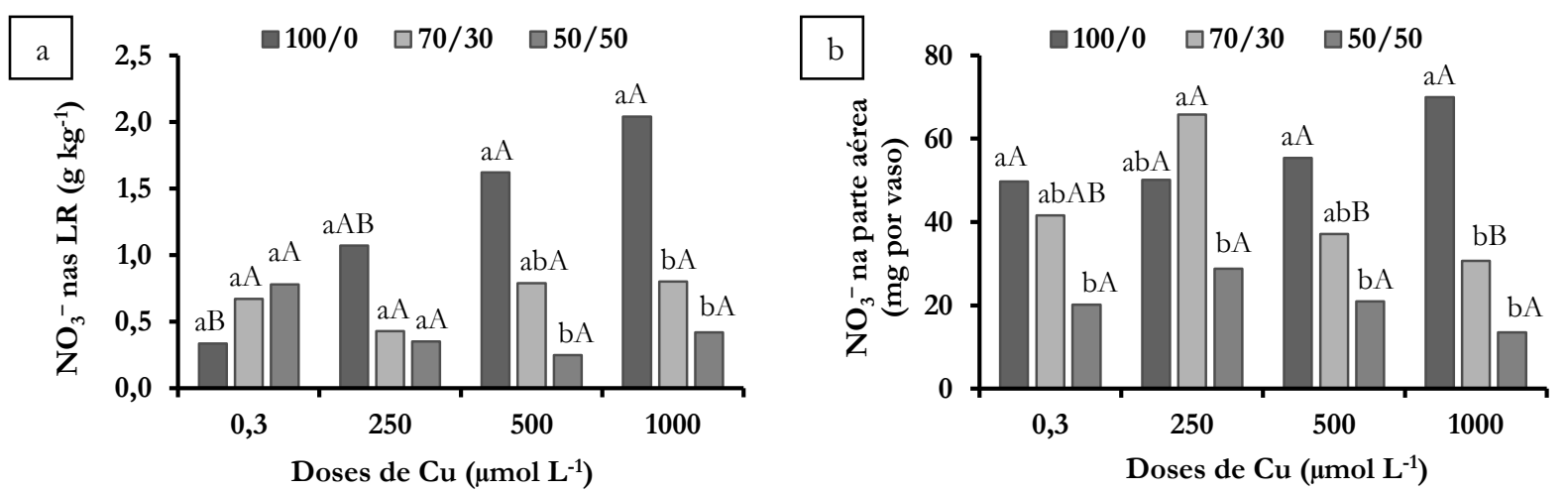

Figura 6. Concentração de $\mathrm{NO}_{3}^{-}$nas lâminas diagnósticas (LR) (a) e acúmulo de $\mathrm{NO}_{3}{ }^{-}$na parte aérea (b) do capim tanzânia no primeiro corte em função de doses de $\mathrm{Cu}$ e proporções de $\mathrm{NO}_{3}{ }^{-} / \mathrm{NH}_{4}{ }^{+}$em solução nutritiva. Letras minúsculas distintas mostram diferença significativa pelo teste de Tukey entre proporções de $\mathrm{NO}_{3}{ }^{-} / \mathrm{NH}_{4}{ }^{+}$dentro de cada dose de $\mathrm{Cu}$ e letras maiúsculas distintas entre as doses de $\mathrm{Cu}$ dentro de cada proporção de $\mathrm{NO}_{3}-\mathrm{NH}_{4}{ }^{+}$. Os resultados originais da figura $6 a$ foram transformados em $\sqrt{x}$ para se ajustar a distribuição normal. Coeficiente de variação (\%) $=27,6$ (a) e 26,7 (b).

A interação proporções de $\mathrm{NO}_{3}{ }^{-} / \mathrm{NH}_{4}{ }^{+} \times$doses de $\mathrm{Cu}$ não foi significativa para a concentração de $\mathrm{N}$ total nas LR do capim, sendo os resultados influenciados apenas pelas proporções de $\mathrm{NO}_{3}{ }^{-} / \mathrm{NH}_{4}{ }^{+}$. As análises mostraram que as maiores concentrações de $\mathrm{N}$ total nas LR do capim foram verificadas na proporção 50/50 de 
$\mathrm{NO}_{3}{ }^{-} / \mathrm{NH}_{4}{ }^{+}$, atingindo patamares de até $26,7 \mathrm{~g} \mathrm{~kg}^{-1}$ e as menores concentrações de $\mathrm{N}$ total na proporção $100 / 0$ e $70 / 30$ de $\mathrm{NO}_{3}{ }^{-} / \mathrm{NH}_{4}{ }^{+}$, estas duas últimas iguais entre si (Figura $7 \mathrm{a}$ ).
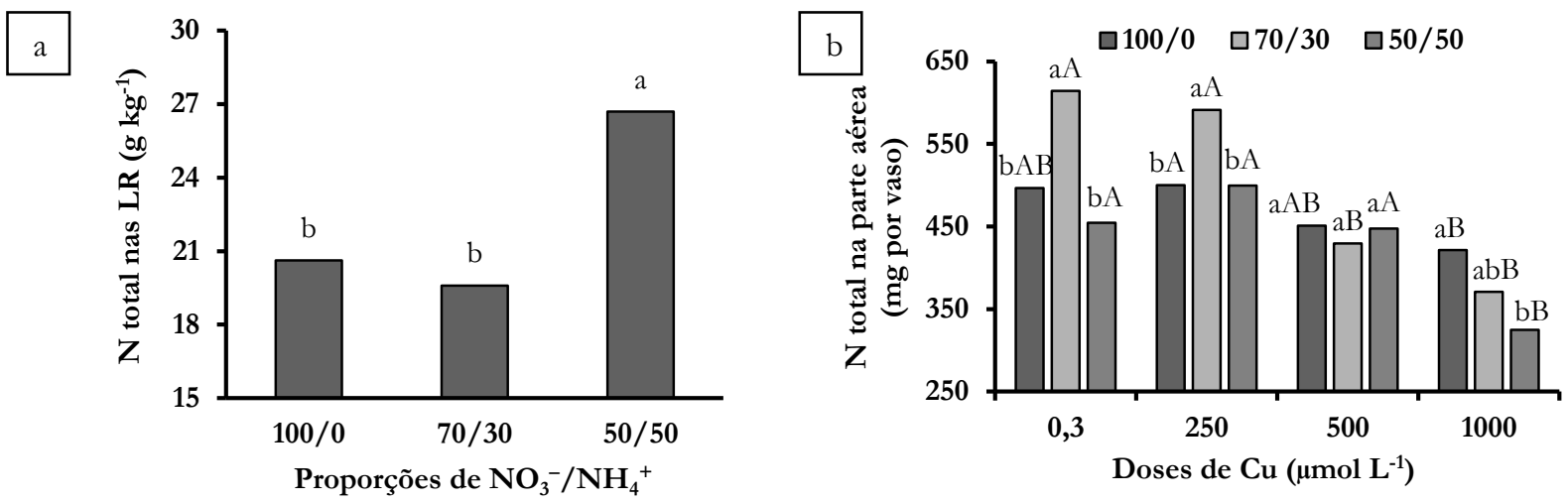

Figura 7. Concentração de $\mathrm{N}$ total nas lâminas diagnósticas (LR) (a) em função de proporções de $\mathrm{NO}_{3}{ }^{-} / \mathrm{NH}_{4}{ }^{+}$e acúmulo de $\mathrm{N}$ total na parte aérea (b) em função de doses de $\mathrm{Cu}$ e proporções de $\mathrm{NO}_{3}{ }^{-} / \mathrm{NH}_{4}{ }^{+}$no primeiro corte do capim tanzânia cultivado em solução nutritiva. Na Figura 7a, letras minúsculas distintas mostram diferença significativa pelo teste de Tukey. Na figura 7b, letras minúsculas distintas mostram diferença significativa pelo teste de Tukey entre proporções de $\mathrm{NO}_{3}{ }^{-} / \mathrm{NH}_{4}{ }^{+}$dentro de cada dose de $\mathrm{Cu}$ e letras maiúsculas distintas entre as doses de $\mathrm{Cu}$ dentro de cada proporção de íons de $\mathrm{NO}_{3}-/ \mathrm{NH}_{4}{ }^{+}$. Coeficiente de variação $(\%)=9,1$ (a) e 7,1 (b).

Para o acúmulo de $\mathrm{N}$ total, verificou-se que a interação proporções de $\mathrm{NO}_{3}-/ \mathrm{NH}_{4}{ }^{+} \times$doses de Cu foi

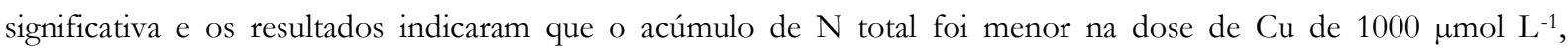
independente do suprimento com proporções de $\mathrm{NO}_{3}{ }^{-} / \mathrm{NH}_{4}{ }^{+}$(Figura $7 \mathrm{~b}$ ). No entanto, a diferença de valor da menor para a maior dose de $\mathrm{Cu}$ foi superior nas plantas cultivadas com $70 / 30$ de $\mathrm{NO}_{3}{ }^{-} / \mathrm{NH}_{4}{ }^{+}$e inferior nas plantas cultivadas com $\mathrm{N}$ na forma de $\mathrm{NO}_{3}^{-}$(Figura $7 \mathrm{~b}$ ).

\subsubsection{Atividade das enzimas envolvidas na assimilação de nitrogênio}

A interação proporções de $\mathrm{NO}_{3}{ }^{-} / \mathrm{NH}_{4}{ }^{+} \times$doses de $\mathrm{Cu}$ foi significativa para as atividades da $\mathrm{NR}$ (Figura 8a) e GS (Figura 8b) nas LR. Destaque para as doses de Cu de 500 e $1000 \mu \mathrm{mol} \mathrm{L}^{-1}$ em que a atividade da NR foi maior nas plantas supridas com 100/0 de $\mathrm{NO}_{3}{ }^{-} / \mathrm{NH}_{4}{ }^{+}$(Figura 8a), em relação às demais proporções. A atividade da glutamina sintetase (GS) nas LR foi maior no capim tanzânia cultivado com doses de Cu de 500 e $1000 \mu \mathrm{mol} \mathrm{L}^{-1}$ e proporções 70/30 e 50/50 de $\mathrm{NO}_{3}{ }^{-} / \mathrm{NH}_{4}{ }^{+}$, comparado a proporção 100/0 de $\mathrm{NO}_{3}{ }^{-} / \mathrm{NH}_{4}{ }^{+}$. A atividade da enzima GS ainda indicou que as plantas supridas exclusivamente com $\mathrm{N}$ na forma de $\mathrm{NO}_{3}{ }^{-}$não apresentaram variação na atividade em função das doses de $\mathrm{Cu}$ (Figura 8b). 

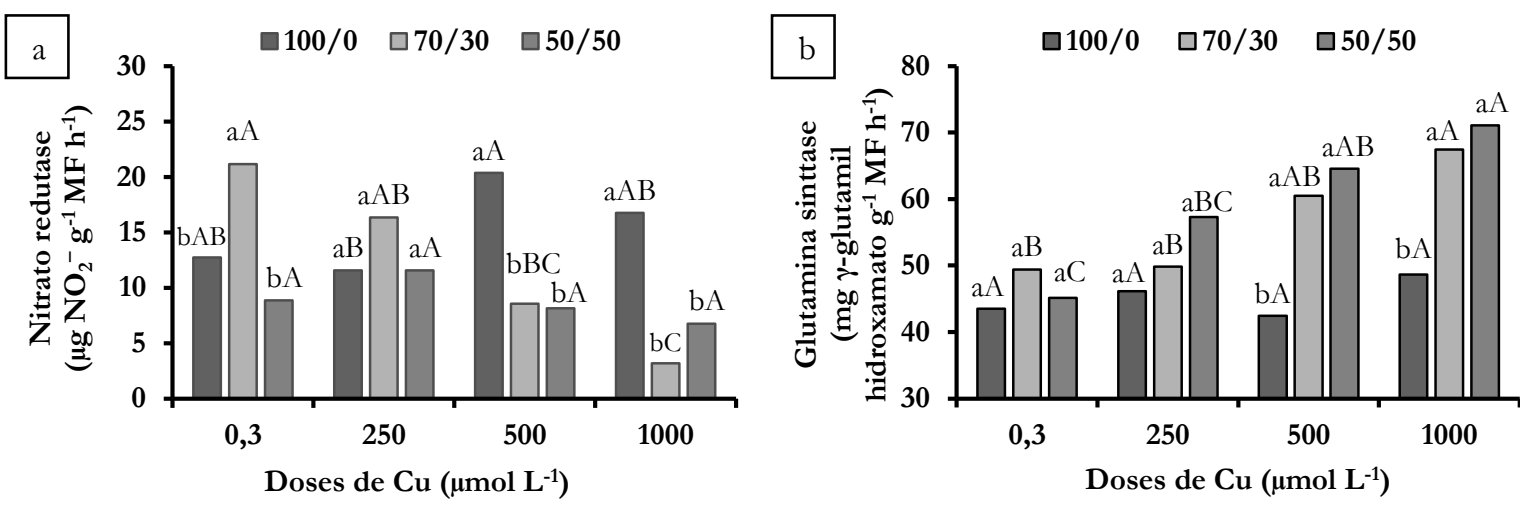

Figura 8. Atividade das enzimas nitrato redutase (a) e glutamina sintetase (b) nas lâminas diagnósticas (LR) do capim tanzânia no primeiro corte em função de doses de $\mathrm{Cu}$ e proporções de $\mathrm{NO}_{3}-\mathrm{NH}_{4}{ }^{+}$em solução nutritiva. Letras minúsculas distintas mostram diferença significativa pelo teste de Tukey entre proporções de $\mathrm{NO}_{3}{ }^{-} / \mathrm{NH}_{4}{ }^{+}$dentro de cada dose de $\mathrm{Cu}$ e letras maiúsculas distintas entre as doses de $\mathrm{Cu}$ dentro de cada proporção de $\mathrm{NO}_{3}{ }^{-} / \mathrm{NH}_{4}{ }^{+}$. Coeficiente de variação (\%) = 30,2 (a) e 10,4 (b).

\subsubsection{Valor SPAD nas folhas diagnósticas, morfogênese e produção de massa da parte aérea}

A interação proporções de $\mathrm{NO}_{3}{ }^{-} / \mathrm{NH}_{4}{ }^{+} \times$doses de $\mathrm{Cu}$ foi significativa para a produção de massa seca da parte aérea e o valor SPAD (Figura 9). As plantas tratadas com proporção de 70/30 de $\mathrm{NO}_{3}^{-} / \mathrm{NH}_{4}{ }^{+}$apresentaram menor produção de massa seca da parte aérea na dose de $\mathrm{Cu}$ de $1000 \mu \mathrm{mol} \mathrm{L} \mathrm{L}^{-1}$. Isso não ocorreu com as plantas que receberam $100 \%$ do $\mathrm{N}$ na forma de $\mathrm{NO}_{3}{ }^{-}$, uma vez que as doses de $\mathrm{Cu}$ não afetaram a produção de massa seca da parte aérea nessas plantas (Figura 9a). Na proporção 50/50 de $\mathrm{NO}_{3}{ }^{-} / \mathrm{NH}_{4}{ }^{+}$, as doses de Cu resultaram em menor massa seca da parte aérea apenas na dose $1000 \mu \mathrm{mol} \mathrm{L} \mathrm{L}^{-1}$, em relação às demais doses de $\mathrm{Cu}$, as quais promovem igual produção de massa (Figura 9a). Para o valor SPAD, foi verificado que essa variável não foi influenciada pelas doses de $\mathrm{Cu}$ quando as plantas foram cultivadas com $\mathrm{N}$ na forma de $\mathrm{NO}_{3}{ }^{-}$, tal qual ocorreu com a produção de massa seca (Figura 9b). Em contrapartida, plantas crescidas em proporções de 70/30 e 50/50 de $\mathrm{NO}_{3}{ }^{-} / \mathrm{NH}_{4}{ }^{+}$e doses de $\mathrm{Cu}$ de $500 \mu \mathrm{mol} \mathrm{L}-1$ apresentaram, respectivamente, média do valor SPAD igual e menor do que plantas crescidas com N na forma de $\mathrm{NO}_{3}^{-}$(Figura 9b). Na dose de $\mathrm{Cu}$ de $1000 \mu \mathrm{mol} \mathrm{L}{ }^{-1}$, a média do valor SPAD foi menor nas plantas que receberam 70/30 de $\mathrm{NO}_{3}{ }^{-} / \mathrm{NH}_{4}{ }^{+}$e maior nas plantas que receberam $\mathrm{N}$ na forma de $\mathrm{NO}_{3}{ }^{-}$, sendo a média da proporção $50 / 50$ de $\mathrm{NO}_{3}{ }^{-} / \mathrm{NH}_{4}{ }^{+}$maior que a obtida na proporção $70 / 30$ de $\mathrm{NO}_{3}{ }^{-} / \mathrm{NH}_{4}{ }^{+}$. 

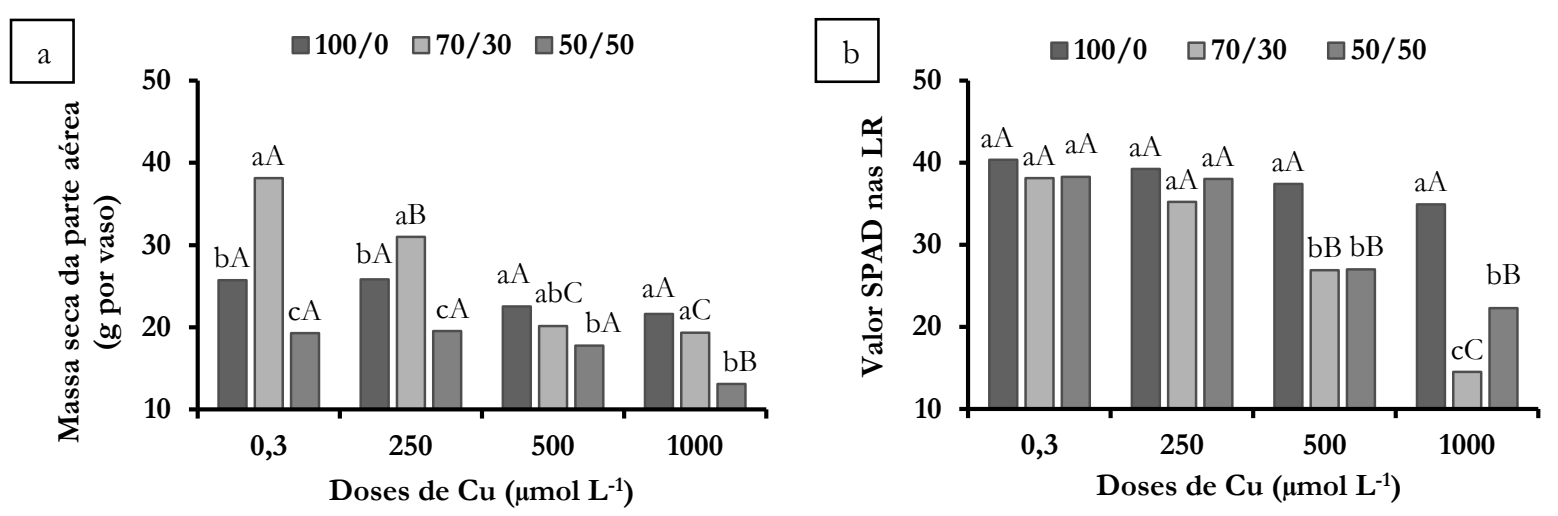

Figura 9. Produção de massa seca da parte aérea (a) e valor SPAD nas lâminas diagnósticas (b) do capim tanzânia no primeiro corte em função de doses de $\mathrm{Cu}$ e proporções de $\mathrm{NO}_{3}-\mathrm{NH}_{4}{ }^{+}$em solução nutritiva. Letras minúsculas distintas mostram diferença significativa pelo teste de Tukey entre proporções de $\mathrm{NO}_{3}{ }^{-} / \mathrm{NH}_{4}{ }^{+}$dentro de cada dose de $\mathrm{Cu}$ e letras maiúsculas distintas entre as doses de $\mathrm{Cu}$ dentro de cada proporção de $\mathrm{NO}_{3}{ }^{-} / \mathrm{NH}_{4}{ }^{+}$. Os resultados originais da figura 9a foram transformados em $\sqrt{x}$ para se ajustar a distribuição normal. Coeficiente de variação (\%) $=4,8$ (a) e 7,44 (Figura 9b).
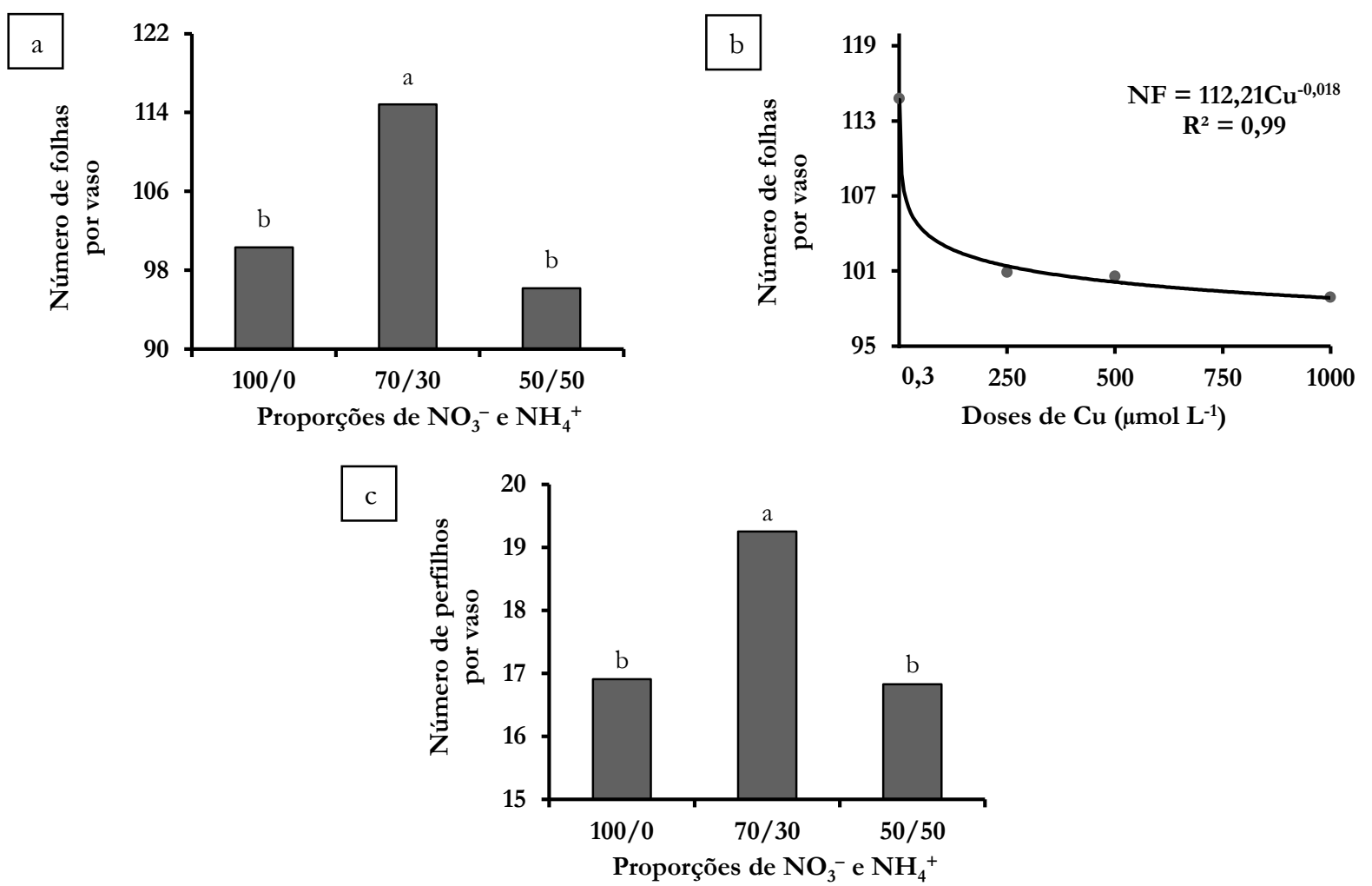

Figura 10. Número de folhas em função de proporções de $\mathrm{NO}_{3}{ }^{-} / \mathrm{NH}_{4}{ }^{+}$(a) ou doses de $\mathrm{Cu}$ (b) e número de perfilhos em função de proporções de $\mathrm{NO}_{3}-\mathrm{NH}_{4}{ }^{+}$(c) em solução nutritiva, no primeiro corte do capim tanzânia. Nas figuras 10a e 10c, letras minúsculas distintas mostram diferença significativa pelo teste de Tukey. Coeficiente de variação (\%) = 7,2 (a, b) e 9,8 (c).

A interação proporções de $\mathrm{NO}_{3}{ }^{-} / \mathrm{NH}_{4}{ }^{+} \times$doses de $\mathrm{Cu}$ não foi significativa para o número de folhas e perfilhos do capim. Em contrapartida, as proporções de $\mathrm{NO}_{3}{ }^{-} / \mathrm{NH}_{4}{ }^{+}$ou doses de $\mathrm{Cu}$ influenciaram isoladamente o número de folhas (Figura 10a, b), apesar do número de perfilhos do capim ter sido afetado apenas pelas proporções de $\mathrm{NO}_{3}{ }^{-} / \mathrm{NH}_{4}{ }^{+}$(Figura 10c). Os resultados indicaram que o número de folhas do capim foi maior na proporção 70/30 de $\mathrm{NO}_{3}^{-} / \mathrm{NH}_{4}{ }^{+}$(Figura 10a), em comparação às demais proporções de $\mathrm{NO}_{3}{ }^{-} / \mathrm{NH}_{4}{ }^{+}$. O número de folhas foi maior também na mais baixa dose de $\mathrm{Cu}$ de $0,3 \mu \mathrm{mol} \mathrm{L} \mathrm{L}^{-1}$, uma vez que apresentou ajuste exponencial decrescente 
(Figura 10b). Quanto ao número de perfilhos, verificou-se que a proporção $70 / 30$ de $\mathrm{NO}_{3}{ }^{-} / \mathrm{NH}_{4}{ }^{+}$resultou no mais alto valor em relação às demais proporções (Figura 10c).

\subsubsection{Segundo corte}

\subsubsection{Sintomas visuais das plantas}

A aplicação do $\mathrm{Cu}$ durante a fase final do primeiro crescimento do capim promoveu efeitos distintos na rebrotação das plantas. O principal efeito constatado foi a morte e não rebrotação do capim tanzânia tratado com proporção $70 / 30$ de $\mathrm{NO}_{3}{ }^{-} / \mathrm{NH}_{4}{ }^{+}$combinada à dose de $\mathrm{Cu}$ de $1000 \mu \mathrm{mol} \mathrm{L}-1$ ou ainda a morte de boa parte das plantas das unidades experimentais tratadas com 50/50 de $\mathrm{NO}_{3}{ }^{-} / \mathrm{NH}_{4}{ }^{+}$e dose de $\mathrm{Cu}$ de $1000 \mu \mathrm{mol} \mathrm{L}-1$ (Figura 11a).
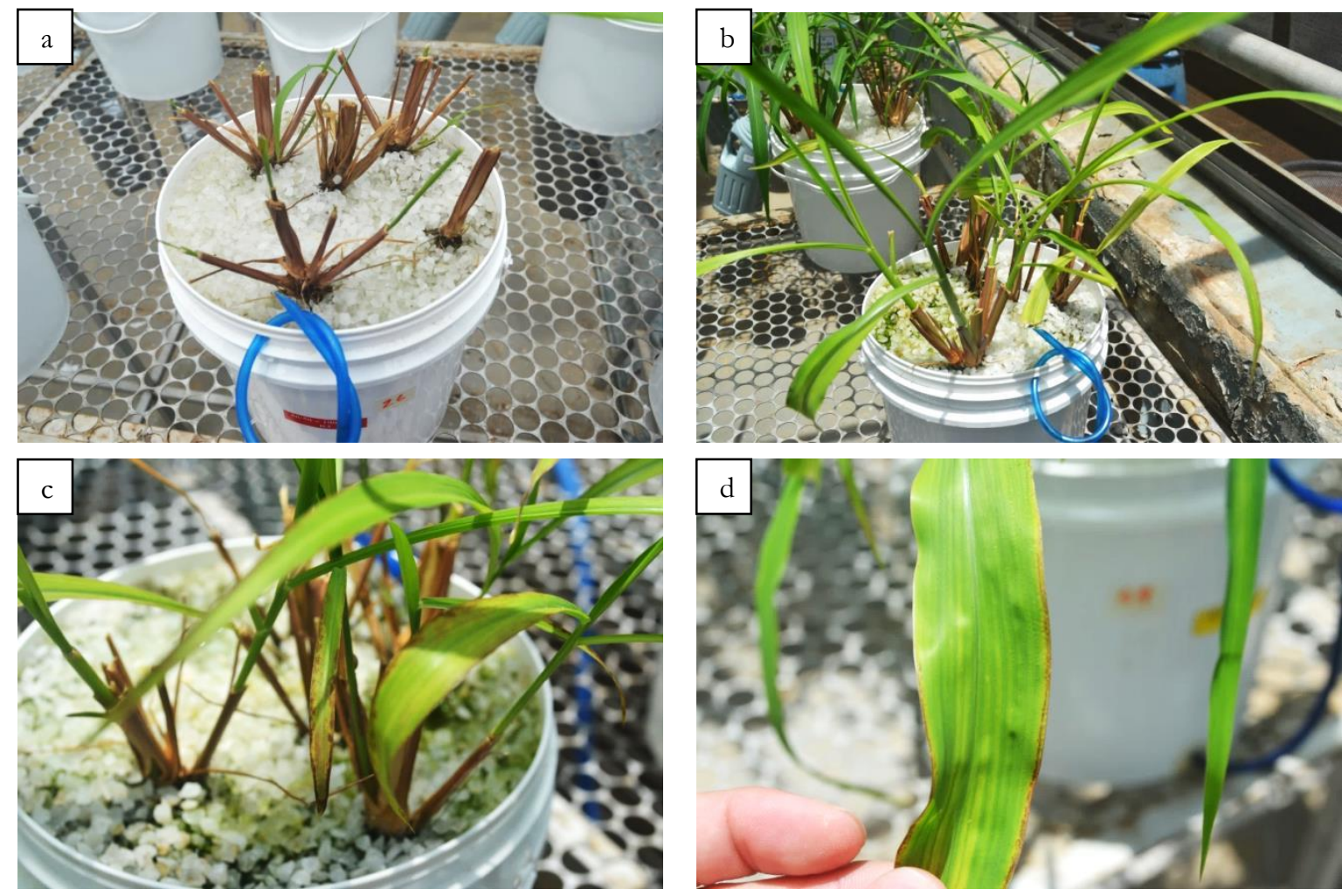

Figura 11. Sintomas visuais de proporções de $50 / 50$ de $\mathrm{NO}_{3}-/ \mathrm{NH}_{4}{ }^{+}$(a, c) e $100 / 0$ de $\mathrm{NO}_{3}-/ \mathrm{NH}_{4}{ }^{+}$(b) em função de dose de $\mathrm{Cu}$ de $1000 \mu \mathrm{mol} \mathrm{L}-1$ residual, assim como na proporção 70/30 de $\mathrm{NO}_{3}^{-} / \mathrm{NH}_{4}{ }^{+}$e dose de $\mathrm{Cu}$ de $500 \mu \mathrm{mol} \mathrm{L}-1$ (d), na fase final do segundo crescimento do capim tanzânia cultivado em solução nutritiva.

Apesar da morte das plantas supridas com 70/30 e 50/50 de $\mathrm{NO}_{3}{ }^{-} / \mathrm{NH}_{4}{ }^{+}$e dose de $\mathrm{Cu}$ de $1000 \mu \mathrm{mol} \mathrm{L}{ }^{-1}$, não ocorreu morte de plantas nas unidades experimentais tratadas com $\mathrm{N}$ na forma de $\mathrm{NO}_{3}{ }^{-}$, em quaisquer doses tóxicas de $\mathrm{Cu}$, mas as plantas cultivadas nas mais altas doses de $\mathrm{Cu}$ apresentaram menor rebrotação, após a exposição ao $\mathrm{Cu}$ de $1000 \mu \mathrm{mol} \mathrm{L}{ }^{-1}$ (Figura 11b). As plantas supridas com proporção 50/50 de $\mathrm{NO}_{3}^{-} / \mathrm{NH}_{4}{ }^{+}$e que foram expostas à dose de $\mathrm{Cu}$ de $1000 \mu \mathrm{mol} \mathrm{L} \mathrm{L}^{-1}$ no primeiro crescimento apresentaram graves problemas no crescimento, perfilhamento e emissão de folhas na rebrotação (Figura 11a, Figura 11c). As plantas apresentaram ainda estrias foliares e em alguns casos necroses das bordas das folhas (Figura 11d). 


\subsubsection{Concentração e acúmulo de minerais na parte aérea}

Foi verificado que a interação proporções de $\mathrm{NO}_{3}{ }^{-} / \mathrm{NH}_{4}{ }^{+} \times$doses de $\mathrm{Cu}$ foi significativa para a concentração de Cu nas LR do capim tanzânia no segundo corte (Figura 12). A concentração de Cu nas LR foi maior nas doses de $\mathrm{Cu}$ de 250 e 500 do que em $0,3 \mu \mathrm{mol} \mathrm{L}{ }^{-1}$, independente da proporção de $\mathrm{NO}_{3}{ }^{-} / \mathrm{NH}_{4}{ }^{+}$(Figura 12). No entanto, na dose de $\mathrm{Cu}$ de $0,3 \mu \mathrm{mol} \mathrm{L} \mathrm{L}^{-1}$ a concentração de $\mathrm{Cu}$ nas LR foi maior nas plantas tratadas com a proporção de $50 / 50 \mathrm{NO}_{3}{ }^{-} / \mathrm{NH}_{4}{ }^{+}$do que nas demais proporções, que foram iguais entre si (Figura 12).

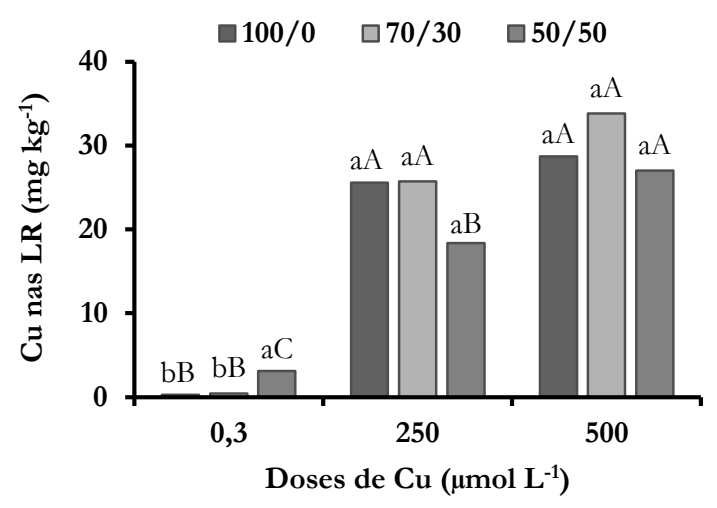

Figura 12. Concentração de $\mathrm{Cu}$ nas lâminas diagnósticas (LR) do capim tanzânia no segundo corte em função de doses de Cu e proporções de $\mathrm{NO}_{3}{ }^{-} / \mathrm{NH}_{4}{ }^{+}$em solução nutritiva. Letras minúsculas distintas mostram diferença significativa pelo teste de Tukey entre proporções de $\mathrm{NO}_{3}{ }^{-} / \mathrm{NH}_{4}{ }^{+}$dentro de cada dose de $\mathrm{Cu}$ e letras maiúsculas distintas entre as doses de $\mathrm{Cu}$ dentro de cada proporção de $\mathrm{NO}_{3}-\mathrm{NH}_{4}{ }^{+}$. Os resultados originais foram transformados em $\sqrt{x}$ para se ajustar a distribuição normal. Coeficiente de variação $(\%)=11,3$.

A interação proporções de $\mathrm{NO}_{3}{ }^{-} / \mathrm{NH}_{4}{ }^{+} \times$doses de $\mathrm{Cu}$ não foi significativa para a concentração e acúmulo de $\mathrm{NO}_{3}{ }^{-}$e $\mathrm{NH}_{4}{ }^{+}$nas $\mathrm{LR}$ e parte aérea do capim, respectivamente. No entanto, o acúmulo de $\mathrm{NH}_{4}{ }^{+}$(Figura 13) e $\mathrm{NO}_{3}^{-}$(Figura 14) na parte aérea foi influenciado isoladamente pelas proporções de $\mathrm{NO}_{3}{ }^{-} / \mathrm{NH}_{4}{ }^{+}$ou doses de $\mathrm{Cu}$. $\mathrm{O}$ acúmulo de $\mathrm{NH}_{4}{ }^{+}$na parte aérea do capim foi maior nas plantas tratadas com $\mathrm{NO}_{3}{ }^{-}$e $\mathrm{NH}_{4}{ }^{+}$e menor naquelas supridas com 100/0 de $\mathrm{NO}_{3}{ }^{-} / \mathrm{NH}_{4}{ }^{+}$(Figura 13a). Por conseguinte, o menor acúmulo de $\mathrm{NH}_{4}{ }^{+}$na parte aérea foi constatado na dose de $\mathrm{Cu}$ de $1000 \mu \mathrm{mol} \mathrm{L}-1$, que apresentou média menor apenas que a dose de $\mathrm{Cu}$ de $0,3 \mu \mathrm{mol} \mathrm{L}-1$ (Figura 13b).
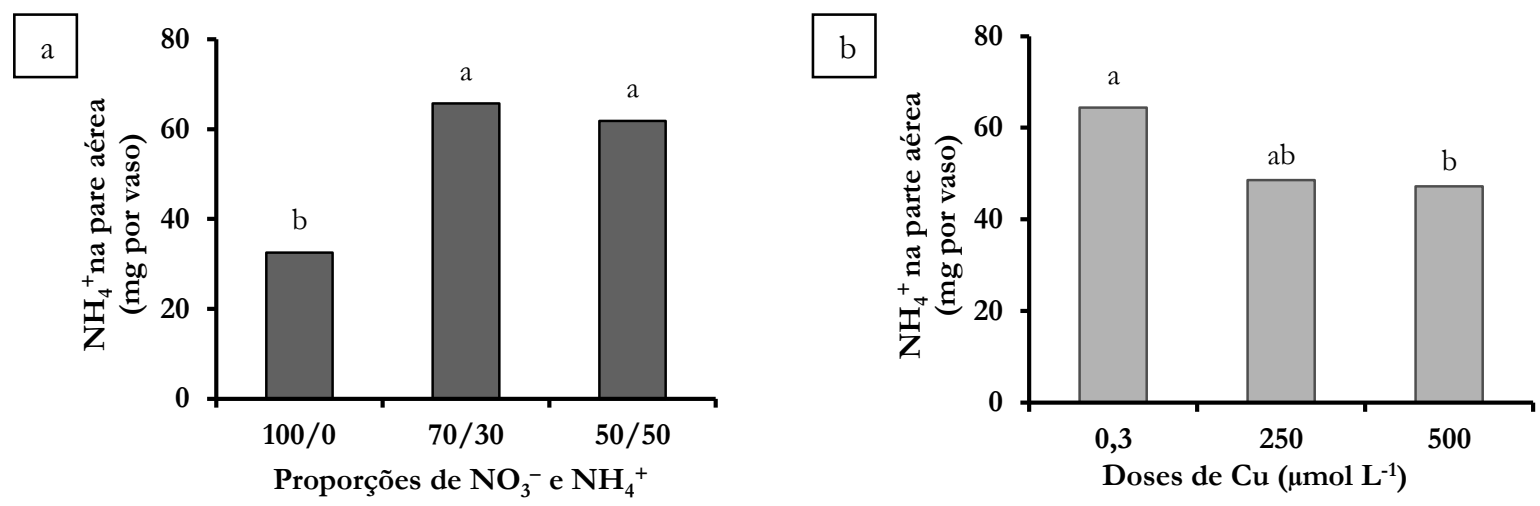

Figura 13. Acúmulo de $\mathrm{NH}_{4}{ }^{+}$na parte aérea do capim tanzânia no segundo corte em função de proporções de $\mathrm{NO}_{3}{ }^{-} / \mathrm{NH}_{4}{ }^{+}$(a) ou doses de $\mathrm{Cu}$ (Figura 13b) em solução nutritiva. Letras minúsculas distintas mostram diferença significativa pelo teste de Tukey. Coeficiente de variação $(\%)=26,2$. 
$\mathrm{O}$ acúmulo de $\mathrm{NO}_{3}{ }^{-}$na parte aérea foi afetado pelas proporções de $\mathrm{NO}_{3}{ }^{-} / \mathrm{NH}_{4}{ }^{+}$e pelas doses de $\mathrm{Cu}$ isoladamente. Os maiores valores de acúmulo de $\mathrm{NO}_{3}{ }^{-}$na parte aérea foram constatados nas plantas que receberam $\mathrm{N}$ exclusivo na forma de $\mathrm{NO}_{3}{ }^{-}$, em comparação às demais proporções (Figura 14a). Para as doses de $\mathrm{Cu}$, a média do acúmulo de $\mathrm{NO}_{3}{ }^{-}$nas plantas expostas às doses de $\mathrm{Cu}$ de $500 \mu \mathrm{mol} \mathrm{L}^{-1}$ foi menor que as demais doses de $\mathrm{Cu}$ de $0,3 \mathrm{e}$ $500 \mu \mathrm{mol} \mathrm{L}-1$ (Figura 14b).
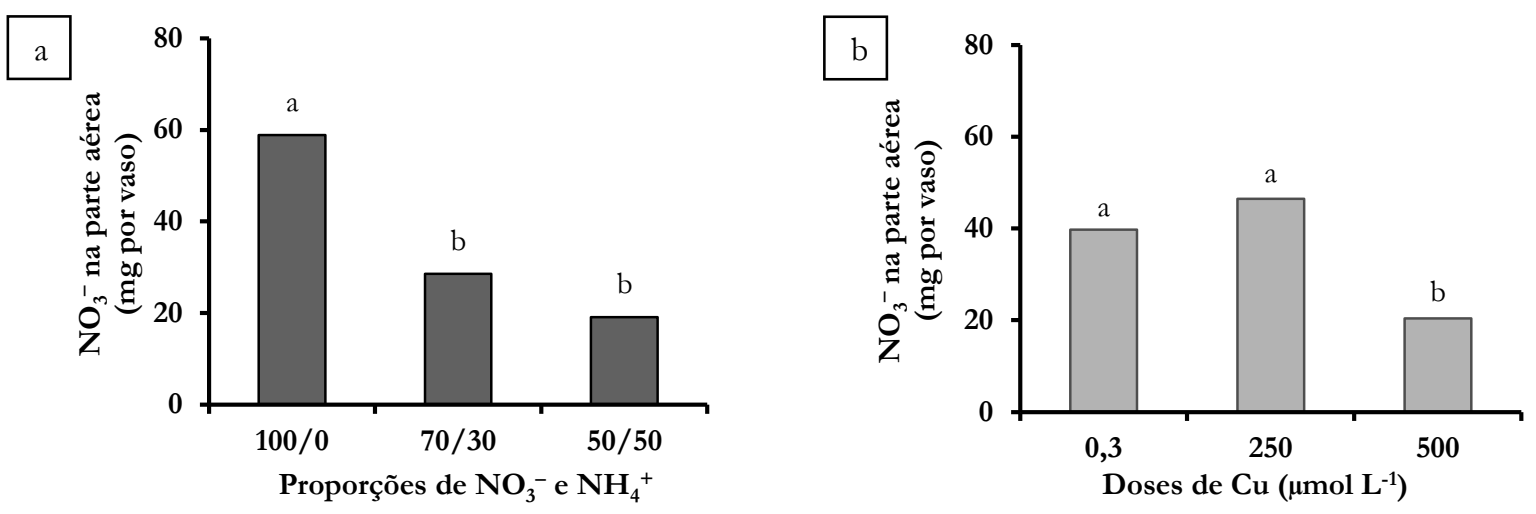

Figura 14. Acúmulo de $\mathrm{NO}_{3}{ }^{-}$na parte aérea do capim tanzânia no segundo corte em função de proporções de $\mathrm{NO}_{3}{ }^{-} / \mathrm{NH}_{4}{ }^{+}$(a) ou doses de $\mathrm{Cu}$ (b) em solução nutritiva. Letras minúsculas distintas mostram diferença significativa pelo teste de Tukey. Os resultados originais foram transformados em $\log x$ para se ajustar a distribuição normal. Coeficiente de variação (\%) $=24,5$.

Para a concentração de $\mathrm{N}$ total nas LR e seu respectivo acúmulo na parte aérea do capim tanzânia no segundo corte, verificou-se que a interação proporções de $\mathrm{NO}_{3}{ }^{-} / \mathrm{NH}_{4}{ }^{+} \times$doses de $\mathrm{Cu}$ foi significativa. Os resultados

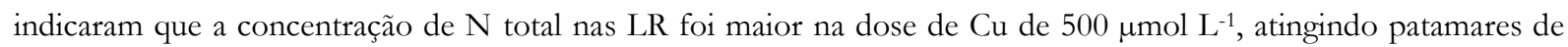
até $40 \mathrm{~g} \mathrm{~kg}^{-1}$ na proporção 70/30 de $\mathrm{NO}_{3}^{-} / \mathrm{NH}_{4}{ }^{+}$(Figura 15a). A concentração de $\mathrm{N}$ total nas LR do capim cultivado com dose de $\mathrm{Cu}$ de $0,3 \mu \mathrm{mol} \mathrm{L}{ }^{-1}$ foi maior nas plantas tratadas com 50/50 de $\mathrm{NO}_{3}{ }^{-} / \mathrm{NH}_{4}{ }^{+}$e menor nas demais proporções. Apesar disso, as doses de Cu não influenciaram a variação na concentração de $\mathrm{N}$ total nas LR do capim tanzânia (Figura 15a). O acúmulo de $\mathrm{N}$ total, de forma contrária, apresentou os menores valores na dose de Cu de $500 \mu \mathrm{mol} \mathrm{L}{ }^{-1}$, independente da proporção de $\mathrm{NO}_{3}{ }^{-} / \mathrm{NH}_{4}{ }^{+}$às quais as plantas foram crescidas. No entanto, na dose de $\mathrm{Cu}$ de $1000 \mu \mathrm{mol} \mathrm{L}{ }^{-1}$ o acúmulo de $\mathrm{N}$ total na parte aérea do capim foi maior na proporção 100/0 do que na proporção $70 / 30$ de $\mathrm{NO}_{3}{ }^{-} / \mathrm{NH}_{4}{ }^{+}$(Figura 15b).
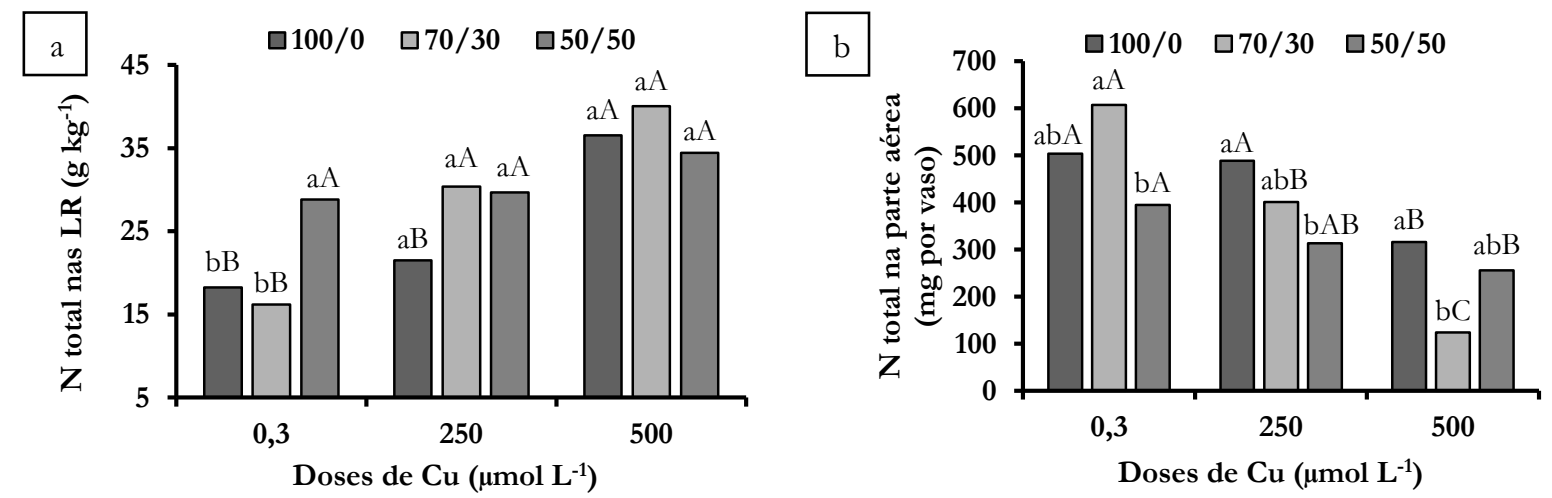

Figura 15. Concentração de $\mathrm{N}$ total nas lâminas diagnósticas (LR) (a) e acúmulo de $\mathrm{N}$ total na parte aérea (b) do capim tanzânia no segundo corte em função de doses de $\mathrm{Cu}$ e proporções de $\mathrm{NO}_{3}-\mathrm{NH}_{4}{ }^{+}$em solução nutritiva. Letras minúsculas distintas mostram diferença significativa pelo teste de Tukey entre proporções de $\mathrm{NO}_{3}-\mathrm{NH}_{4}{ }^{+}$dentro de cada dose de $\mathrm{Cu}$ e letras maiúsculas distintas entre as doses de $\mathrm{Cu}$ dentro de cada proporção de $\mathrm{NO}_{3}{ }^{-} / \mathrm{NH}_{4}{ }^{+}$. Coeficiente de variação $(\%)=17,1$ (a) e 17,2 (b). 


\subsubsection{Concentração e acúmulo de minerais nas raízes}

A interação proporções de $\mathrm{NO}_{3}{ }^{-} / \mathrm{NH}_{4}{ }^{+} \times$doses de $\mathrm{Cu}$ foi significativa para a concentração de $\mathrm{Cu}$ nas raízes (Figura 16). A concentração de $\mathrm{Cu}$ nas raízes foi maior nas mais elevadas doses de $\mathrm{Cu}$, especialmente nas proporções 100/0 e 70/30 de $\mathrm{NO}_{3}{ }^{-} / \mathrm{NH}_{4}{ }^{+}$, esta última atingindo valor de concentração de $\mathrm{Cu}$ de $2566 \mathrm{mg} \mathrm{kg}^{-1}$ (Figura 16a). Nas plantas supridas com $\mathrm{N}$ na forma de $\mathrm{NO}_{3}{ }^{-}$e expostas ao $\mathrm{Cu}$ de $500 \mu \mathrm{mol} \mathrm{L}{ }^{-1}$, a concentração de $\mathrm{Cu}$ foi maior do que nas demais proporções. Entretanto, na dose de $\mathrm{Cu}$ de $1000 \mu \mathrm{mol} \mathrm{L}^{-1}$ as plantas das proporções 100/0 e 70/30 de $\mathrm{NO}_{3}-/ \mathrm{NH}_{4}{ }^{+}$apresentaram maior concentração de $\mathrm{Cu}$, quando comparadas à proporção 50/50 de $\mathrm{NO}_{3}{ }^{-} / \mathrm{NH}_{4}{ }^{+}$(Figura 16).

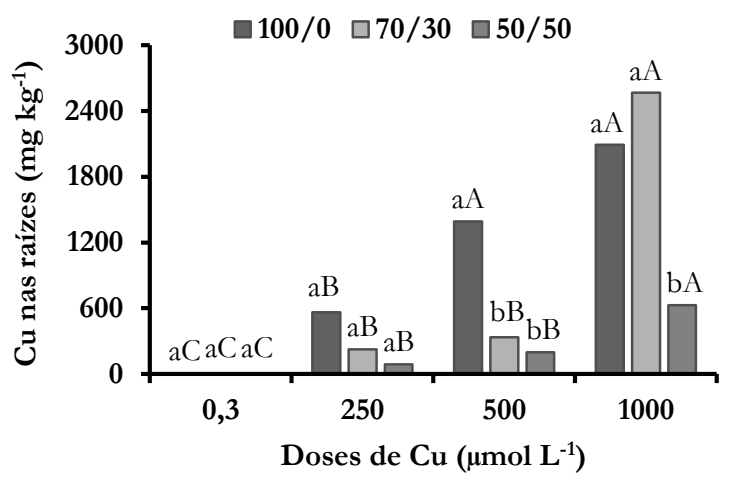

Figura 16. Concentração de $\mathrm{Cu}$ nas raízes do capim tanzânia no segundo corte em função de doses de Cu e proporções de $\mathrm{NO}_{3}-\mathrm{NH}_{4}{ }^{+}$em solução nutritiva. Letras minúsculas distintas mostram diferença significativa pelo teste de Tukey entre proporções de $\mathrm{NO}_{3}-/ \mathrm{NH}_{4}{ }^{+}$dentro de cada dose de $\mathrm{Cu}$ e letras maiúsculas distintas entre as doses de $\mathrm{Cu}$ dentro de cada proporção de $\mathrm{NO}_{3}{ }^{-} / \mathrm{NH}_{4}{ }^{+}$. Os resultados originais foram transformados em $\sqrt{x}$ para se ajustar a distribuição normal. Coeficiente de variação $(\%)=8,4$.

Para a concentração de $\mathrm{NH}_{4}{ }^{+}$nas raízes, verificou-se que a interação proporções de $\mathrm{NO}_{3}{ }^{-} / \mathrm{NH}_{4}{ }^{+} \times$doses de $\mathrm{Cu}$ não foi significativa. Entretanto, a concentração de $\mathrm{NH}_{4}{ }^{+}$nesse órgão foi influenciada isoladamente pelo fator proporção de $\mathrm{NO}_{3}-\mathrm{NH}_{4}{ }^{+}$(Figura 17) e doses de $\mathrm{Cu}$. A concentração de $\mathrm{NH}_{4}^{+}$nas raízes foi maior na proporção 50/50 e menor nessa parte das plantas crescidas na proporção 100/0 de $\mathrm{NO}_{3}{ }^{-} / \mathrm{NH}_{4}{ }^{+}$(Figura 17). Além disso, a concentração de $\mathrm{NH}_{4}+$ foi maior nas raízes do capim na dose de $\mathrm{Cu}$ de 250 em relação à dose de $0,3 \mu \mathrm{mol} \mathrm{L} \mathrm{L}^{-1}$.

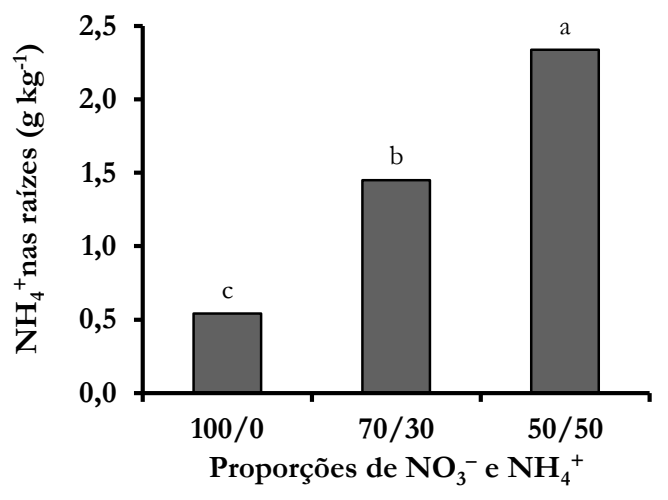

Figura 17. Concentração de $\mathrm{NH}_{4}{ }^{+}$nas raízes do capim tanzânia no segundo corte em função de proporções de $\mathrm{NO}_{3}{ }^{-} / \mathrm{NH}_{4}{ }^{+} \mathrm{em}$ solução nutritiva. Letras minúsculas distintas mostram diferença significativa pelo teste de Tukey. Os resultados originais foram transformados em $\sqrt{x}$ para se ajustar a distribuição normal. Coeficiente de variação (\%) $=20,0$. 
Para o acúmulo de $\mathrm{NH}_{4}{ }^{+}$nas raízes, observou-se significância da interação proporções de $\mathrm{NO}_{3}{ }^{-} / \mathrm{NH}_{4}{ }^{+} \times$ doses de $\mathrm{Cu}$ (Figura 18). Os maiores acúmulos de $\mathrm{NH}_{4}{ }^{+}$nas raízes foram observados nas plantas cultivadas nas proporções 70/30 e 50/50 de $\mathrm{NO}_{3}^{-} / \mathrm{NH}_{4}{ }^{+}$combinadas às doses de $\mathrm{Cu}$ de 0,3 e $250 \mu \mathrm{mol} \mathrm{L} \mathrm{L}^{-1}$, em relação ao suprimento com $\mathrm{N}$ na forma de $\mathrm{NO}_{3}{ }^{-}$. Nas doses de $\mathrm{Cu}$ de 500 e $1000 \mu \mathrm{mol} \mathrm{L}{ }^{-1}$, as raízes das plantas crescidas nas proporções 70/30 e 50/50 de $\mathrm{NO}_{3}^{-} / \mathrm{NH}_{4}{ }^{+}$apresentaram menores médias, quando comparadas às doses de $\mathrm{Cu}$ de 0,3 e $250 \mu \mathrm{mol} \mathrm{L}{ }^{-1}$ (Figura 18). Em plantas supridas com $\mathrm{N}$ na forma de $\mathrm{NO}_{3}{ }^{-}$não houve alteração no acúmulo de $\mathrm{NH}_{4}{ }^{+}$ em função da exposição às doses tóxicas de Cu na solução nutritiva.

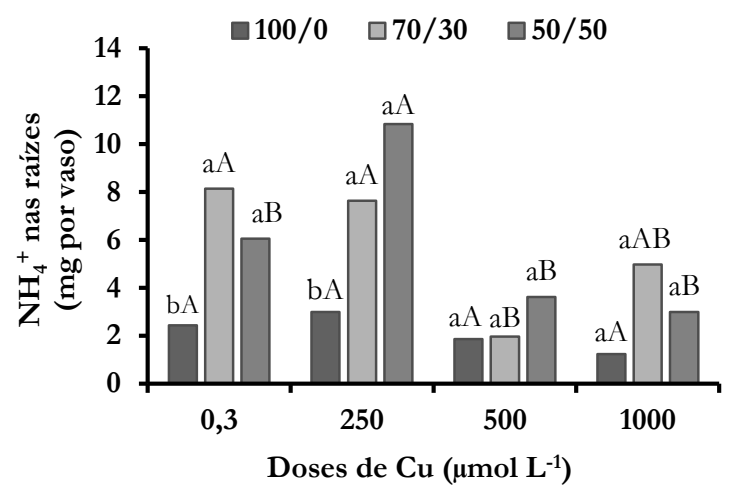

Figura 18. Acúmulo de $\mathrm{NH}_{4}{ }^{+}$nas raízes do capim tanzânia no segundo corte em função de doses de $\mathrm{Cu}$ e proporções de $\mathrm{NO}_{3}{ }^{-} / \mathrm{NH}_{4}{ }^{+}$em solução nutritiva. Letras minúsculas distintas mostram diferença significativa pelo teste de Tukey entre proporções de $\mathrm{NO}_{3}-/ \mathrm{NH}_{4}{ }^{+}$dentro de cada dose de $\mathrm{Cu}$ e letras maúsculas distintas entre as doses de $\mathrm{Cu}$ dentro de cada proporção de $\mathrm{NO}_{3}-/ \mathrm{NH}_{4}{ }^{+}$. Os resultados originais foram transformados em $\sqrt{x}$ para se ajustar a distribuição normal. Coeficiente de variação $(\%)=20,0$.

Para a concentração e acúmulo de $\mathrm{NO}_{3}{ }^{-}$nas raízes do capim tanzânia, verificou-se que a interação proporções de $\mathrm{NO}_{3}{ }^{-} / \mathrm{NH}_{4}{ }^{+} \times$doses de $\mathrm{Cu}$ foi significativa (Figura 19). Os resultados indicaram que a concentração e o acúmulo de $\mathrm{NO}_{3}{ }^{-}$nas raízes foram maiores nas elevadas doses de $\mathrm{Cu}$, mas somente nas plantas tratadas com $\mathrm{N}$ na forma de $\mathrm{NO}_{3}{ }^{-}$(Figura 19). Nas demais proporções, as doses de $\mathrm{Cu}$ não interferiram na variação da concentração (Figura 19a) e acúmulo (Figura 19b) de $\mathrm{NO}_{3}{ }^{-}$nas raízes. Nas doses de $\mathrm{Cu}$ de 500 e $1000 \mu \mathrm{mol} \mathrm{L}{ }^{-1}$ os valores de concentração e acúmulo de $\mathrm{NO}_{3}{ }^{-}$nas parcelas supridas com $100 \%$ do $\mathrm{N}$ na forma de $\mathrm{NO}_{3}{ }^{-}$foram maiores do que nas demais proporções de $\mathrm{NO}_{3}-/ \mathrm{NH}_{4}{ }^{+}$(Figura 19a, b). 

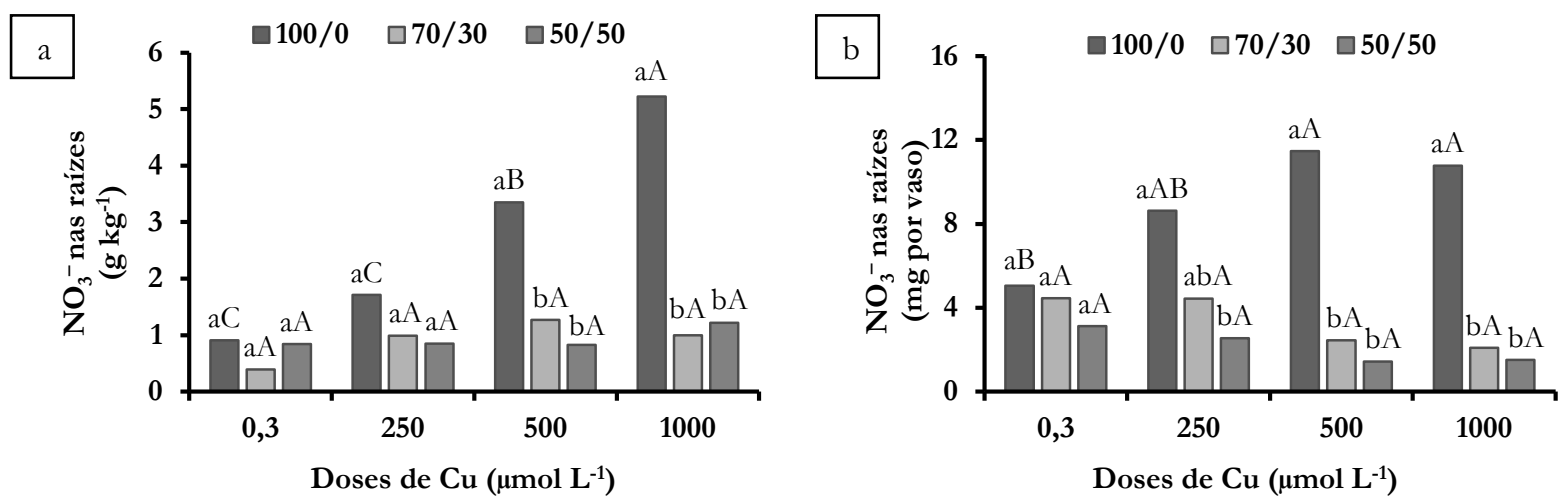

Figura 19. Concentração (a) e acúmulo (b) de $\mathrm{NO}_{3}{ }^{-}$nas raízes do capim tanzânia no segundo corte em função de doses de $\mathrm{Cu}$ e proporções de $\mathrm{NO}_{3}-/ \mathrm{NH}_{4}{ }^{+}$em solução nutritiva. Letras minúsculas distintas mostram diferença significativa pelo teste de Tukey entre proporções de $\mathrm{NO}_{3}-\mathrm{NH}_{4}{ }^{+}$dentro de cada dose de $\mathrm{Cu}$ e letras maiúsculas distintas entre as doses de $\mathrm{Cu}$ dentro de cada proporção de $\mathrm{NO}_{3}-/ \mathrm{NH}_{4}{ }^{+}$. Os resultados originais foram transformados em $\sqrt{x}$ para se ajustar a distribuição normal. Coeficiente de variação $(\%)=19,1$ (a) e 21,1 (b).

A interação proporções de $\mathrm{NO}_{3}{ }^{-} / \mathrm{NH}_{4}{ }^{+} \times$doses de $\mathrm{Cu}$ foi significativa para a concentração e acúmulo de $\mathrm{N}$ total nas raízes do capim (Figura 20). Os resultados para a concentração de $\mathrm{N}$ total nas raízes mostraram que as doses de $\mathrm{Cu}$ tiveram influência na variável, mas apenas nas plantas recebendo a proporção $70 / 30$ de $\mathrm{NO}_{3}{ }^{-} / \mathrm{NH}_{4}{ }^{+}$. Nessa proporção $70 / 30$ de $\mathrm{NO}_{3}{ }^{-} / \mathrm{NH}_{4}{ }^{+}$, a maior média de concentração de $\mathrm{N}$ total nas raízes foi constatada na dose de $\mathrm{Cu}$ de $250 \mu \mathrm{mol} \mathrm{L}{ }^{-1}$ e as menores médias na dose de Cu de 0,3 e $1000 \mu \mathrm{mol} \mathrm{L}-1$ (Figura 20a). Para o acúmulo de N total nas raízes, as análises mostraram que independente das proporções de $\mathrm{NO}_{3}{ }^{-} / \mathrm{NH}_{4}{ }^{+}$nas quais as plantas foram crescidas, os menores valores de acúmulo de $\mathrm{N}$ total nas raízes foram constatados na dose de $\mathrm{Cu}$ de $1000 \mu \mathrm{mol} \mathrm{\textrm {L } ^ { - 1 }}$. Nas doses de $\mathrm{Cu}$ de 250 e $500 \mu \mathrm{mol} \mathrm{L}^{-1}$ os valores de acúmulo de $\mathrm{N}$ total nas raízes das plantas cultivadas com $\mathrm{N}$ na forma de $\mathrm{NO}_{3}{ }^{-}$foram maiores que os valores apresentados naquelas plantas cultivadas com 50/50 de $\mathrm{NO}_{3}{ }^{-} / \mathrm{NH}_{4}{ }^{+}$ (Figura 20b). Especialmente na dose de $\mathrm{Cu}$ de $500 \mu \mathrm{mol} \mathrm{L}{ }^{-1}$, as plantas tratadas com $\mathrm{N}$ exclusivo na forma de $\mathrm{NO}_{3}{ }^{-}$ apresentaram médias maiores que as plantas cultivadas nas demais proporções de $\mathrm{NO}_{3}{ }^{-} / \mathrm{NH}_{4}{ }^{+}$(Figura $20 \mathrm{~b}$ ).
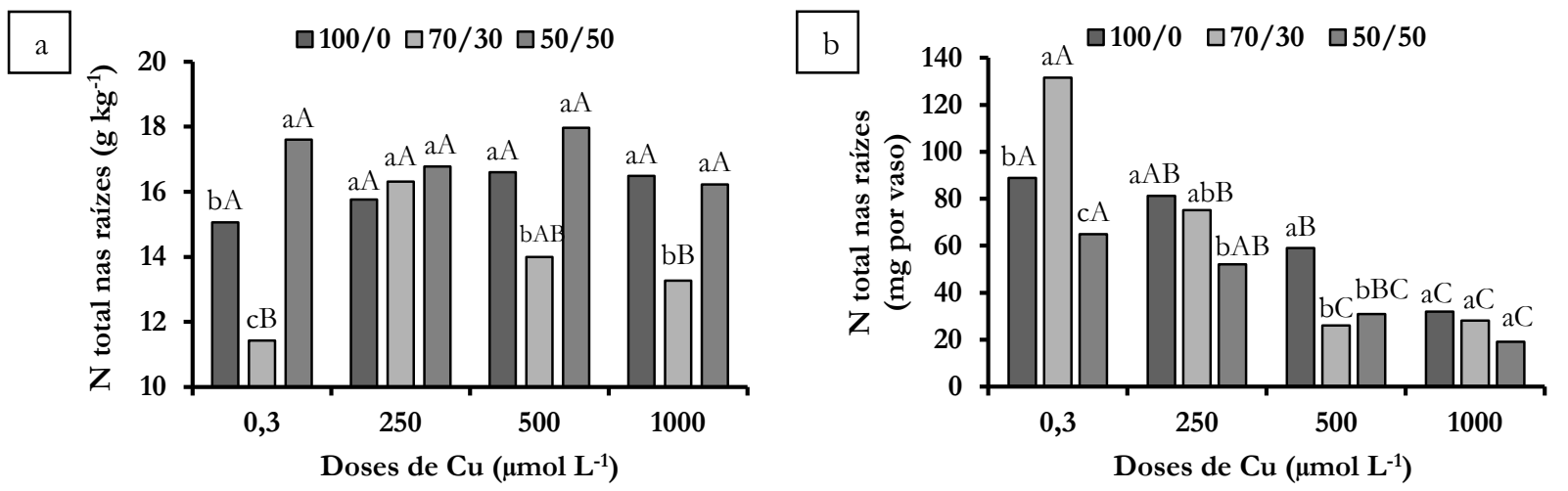

Figura 20. Concentração (a) e acúmulo (b) de $\mathrm{N}$ total nas raízes do capim tanzânia no segundo corte em função de doses de Cu e proporções de $\mathrm{NO}_{3}-\mathrm{NH}_{4}{ }^{+}$em solução nutritiva. Letras minúsculas distintas mostram diferença significativa pelo teste de Tukey entre proporções de $\mathrm{NO}_{3}-\mathrm{NH}_{4}{ }^{+}$dentro de cada dose de $\mathrm{Cu}$ e letras maiúsculas distintas entre as doses de $\mathrm{Cu}$ dentro de cada proporção de $\mathrm{NO}_{3}-\mathrm{NH}_{4}{ }^{+}$. Coeficiente de variação $(\%)=7,5$ (a) e 20,0 (b). 


\subsubsection{Atividades das enzimas envolvidas na assimilação de nitrogênio}

Os resultados mostraram que a interação proporções de $\mathrm{NO}_{3}{ }^{-} / \mathrm{NH}_{4}{ }^{+} \times$doses de $\mathrm{Cu}$ foi significativa para a atividade da NR (Figura 21a), sendo a atividade da GS não significativa no segundo corte. A atividade da enzima NR nas LR foi maior somente nas plantas que receberam as doses de $\mathrm{Cu}$ de 250 e $500 \mu \mathrm{mol} \mathrm{L}{ }^{-1}$ em associação à proporção de 70/30 de $\mathrm{NO}_{3}{ }^{-} / \mathrm{NH}_{4}{ }^{+}$. A atividade da $\mathrm{NR}$ nas LR de plantas tratadas com as demais proporções de $\mathrm{NO}_{3}{ }^{-} / \mathrm{NH}_{4}{ }^{+}$não foram influenciadas pelas doses de $\mathrm{Cu}$ (Figura 21a).

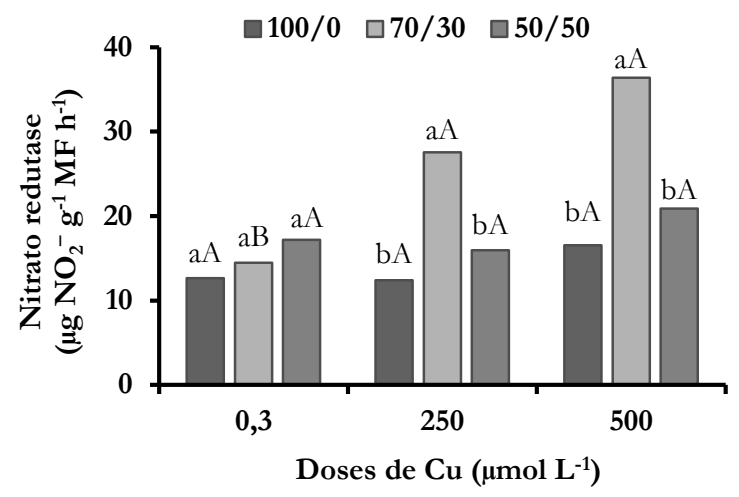

Figura 21. Atividade da enzima nitrato redutase nas lâminas diagnósticas do capim tanzânia no segundo corte em função de doses de $\mathrm{Cu}$ e proporções de $\mathrm{NO}_{3}-\mathrm{NH}_{4}{ }^{+}$em solução nutritiva. Letras minúsculas distintas mostram diferença significativa pelo teste de Tukey entre proporções de $\mathrm{NO}_{3}-\mathrm{NH}_{4}{ }^{+}$dentro de cada dose de $\mathrm{Cu}$ e letras maiúsculas distintas entre as doses de $\mathrm{Cu}$ dentro de cada proporção de $\mathrm{NO}_{3}-\mathrm{NH}_{4}{ }^{+}$. Os resultados originais foram transformados em $\sqrt{x}$ para se ajustar a distribuição normal. Coeficiente de variação $(\%)=13,4$.

\subsubsection{Valor SPAD das folhas diagnósticas, morfogênese e produção de massa}

As análises indicaram que, à exceção do valor SPAD que não variou significativamente em função da combinação dos níveis dos fatores, os atributos produção de massa seca e número de folhas e de perfilhos foram significativos para a interação proporções de $\mathrm{NO}_{3}-\mathrm{NH}_{4}{ }^{+} \times$doses de $\mathrm{Cu}$ (Figura 22). Os resultados apontam que as doses de $\mathrm{Cu}$ na solução nutritiva proporcionou menor produção de massa seca (Figura 22a), menor número de folhas (Figura 22b) e menor número de perfilhos (Figura 22c), principalmente nas plantas supridas com 70/30 de $\mathrm{NO}_{3}{ }^{-} / \mathrm{NH}_{4}{ }^{+}$. Nas plantas cultivadas nessas proporções cada elevação na dose de Cu proporcionou diferença significativa nas variáveis (Figura 22c). Nas plantas que receberam as proporções $100 / 0$ e $50 / 50$ de $\mathrm{NO}_{3}^{-} / \mathrm{NH}_{4}{ }^{+}$, as variações causadas pelas doses de $\mathrm{Cu}$ se restringiram à produção de massa seca da parte aérea (Figura 22c), que apresentou média menor na dose de $\mathrm{Cu}$ de $500 \mu \mathrm{mol} \mathrm{L}-1$ comparada à dose de $\mathrm{Cu}$ de 0,3 e $250 \mu \mathrm{mol} \mathrm{L}{ }^{-1}$. 

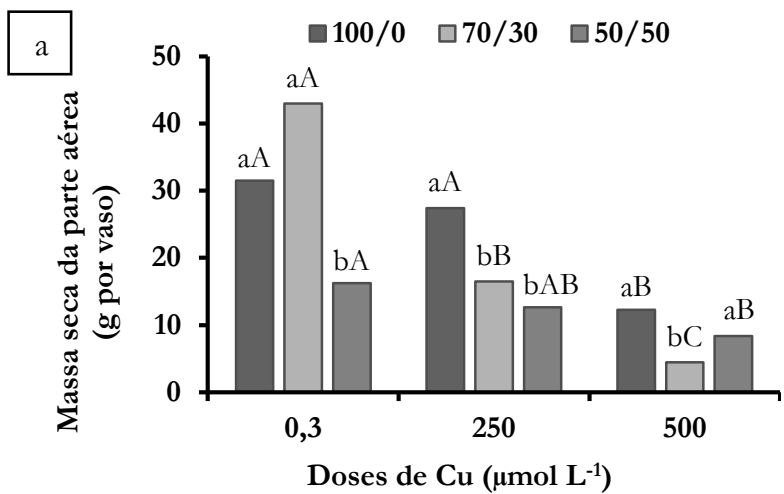

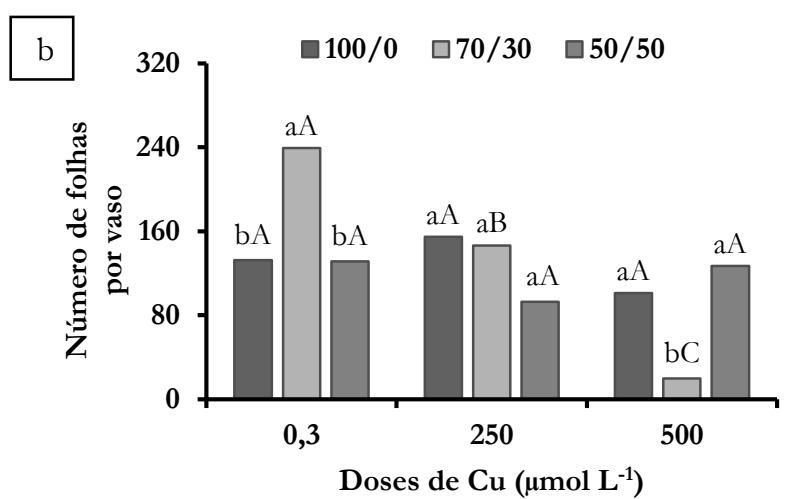

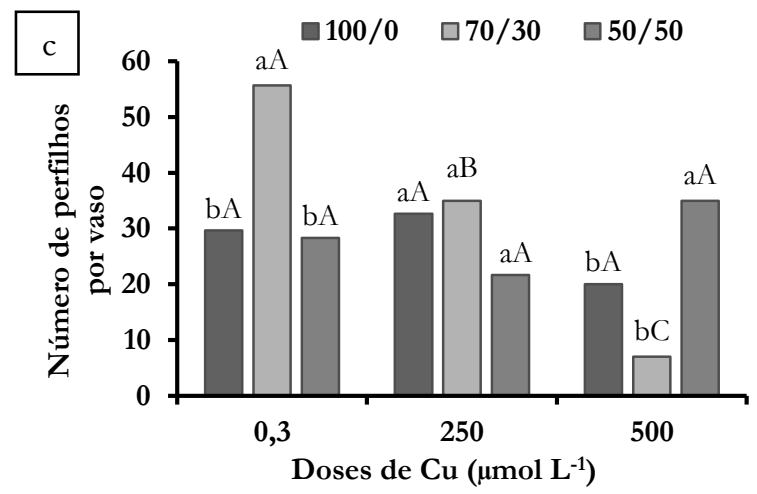

Figura 22. Produção de massa seca da parte aérea (a), número de folhas (b) e número de perfilhos (c) do capim tanzânia no segundo corte em função de doses de $\mathrm{Cu}$ e proporções de $\mathrm{NO}_{3}{ }^{-} / \mathrm{NH}_{4}{ }^{+}$em solução nutritiva. Letras minúsculas distintas mostram diferença significativa pelo teste de Tukey entre proporções de $\mathrm{NO}_{3}{ }^{-} / \mathrm{NH}_{4}{ }^{+}$dentro de cada dose de $\mathrm{Cu}$ e letras maiúsculas distintas entre as doses de $\mathrm{Cu}$ dentro de cada proporção de $\mathrm{NO}_{3}-/ \mathrm{NH}_{4}{ }^{+}$. Os resultados originais das figuras 22a foram transformados em $\sqrt{x}$ para se ajustar a distribuição normal. Coeficiente de variação (\%) $=10,8$ (a), 25,4 (b) e 22,9 (c).

\subsubsection{Produção de massa de raízes e superfície radicular}

A interação proporções de $\mathrm{NO}_{3}{ }^{-} / \mathrm{NH}_{4}{ }^{+} \times$doses de $\mathrm{Cu}$ foi significativa para a produção de massa seca de raízes e superfície radicular (Figura 23). Os resultados para a massa seca de raízes mostraram que as médias foram menores na dose de $\mathrm{Cu}$ de $1000 \mu \mathrm{mol} \mathrm{L}{ }^{-1}$ em solução nutritiva, independente das proporções de $\mathrm{NO}_{3}^{-} / \mathrm{NH}_{4}{ }^{+}$. Todavia, na proporção 70/30 de $\mathrm{NO}_{3}{ }^{-} / \mathrm{NH}_{4}{ }^{+}$ocorreu maior diferença de média da dose de $\mathrm{Cu}$ de 0,3 em relação à dose $1000 \mu \mathrm{mol} \mathrm{L}{ }^{-1}$, quando comparada às demais proporções de $\mathrm{NO}_{3}^{-} / \mathrm{NH}_{4}^{+}$(Figura 23a). $\mathrm{O}$ resultado de superfície radicular apresentou padrão similar, o qual indicou que somente o capim tanzânia suprido com 70/30 de $\mathrm{NO}_{3}{ }^{-} / \mathrm{NH}_{4}{ }^{+}$apresentou variação das médias em função das doses de $\mathrm{Cu}$, com os menores valores de superfície radicular constatados na dose de $\mathrm{Cu}$ de $1000 \mu \mathrm{mol} \mathrm{L}-1$ (Figura 23b). As proporções 100/0 e 50/50 de $\mathrm{NO}_{3}^{-} / \mathrm{NH}_{4}{ }^{+}$ não apresentaram valores de superfície radicular que variaram em função das doses de Cu (Figura 23b). 

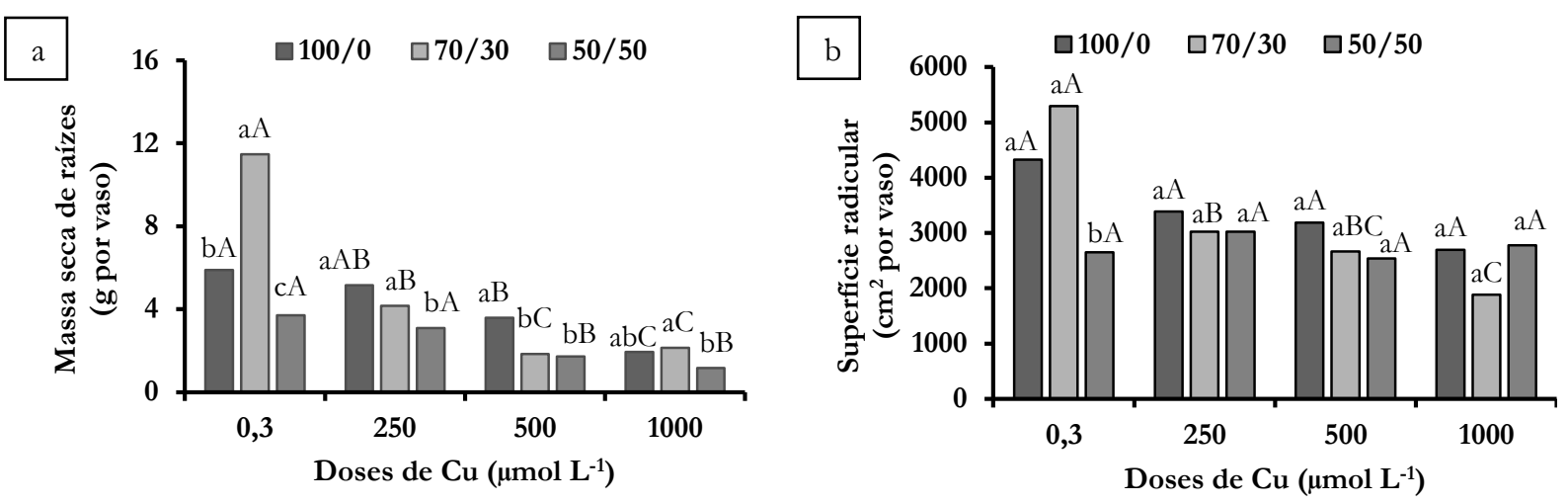

Figura 23. Produção de massa seca de raízes (a) e superfície radicular (b) do capim tanzânia no segundo corte em função de doses de $\mathrm{Cu}$ e proporções de $\mathrm{NO}_{3}{ }^{-} / \mathrm{NH}_{4}{ }^{+}$em solução nutritiva. Letras minúsculas distintas mostram diferença significativa pelo teste de Tukey entre proporções de $\mathrm{NO}_{3}{ }^{-} / \mathrm{NH}_{4}{ }^{+}$dentro de cada dose de $\mathrm{Cu}$ e letras maiúsculas distintas entre as doses de $\mathrm{Cu}$ dentro de cada proporção de $\mathrm{NO}_{3}{ }^{-} / \mathrm{NH}_{4}{ }^{+}$. Os resultados originais das figuras 23 a foram transformados em $\sqrt{x}$ para se ajustar a distribuição normal. Coeficiente de variação (\%) = 9,5 (a) e 2,6 (b).

\subsection{Discussão}

A toxidez por $\mathrm{Cu}$ constatada visualmente nas plantas foi confirmada pela da concentração de Cu nas LR do capim. As plantas com elevadas concentrações do metal nas LR também apresentaram maior severidade da toxidez, especialmente nas mais elevadas doses de $\mathrm{Cu}$ combinadas ao suprimento com $\mathrm{NO}_{3}{ }^{-} \mathrm{e} \mathrm{NH}_{4}{ }^{+}$, efeito oposto ao que ocorreu com as plantas cultivadas com $\mathrm{N}$ na forma de $\mathrm{NO}_{3}{ }^{-}$. Isso sugere que o transporte de Cu das raízes para a parte aérea foi alterado pelas proporções de $\mathrm{NO}_{3}{ }^{-} / \mathrm{NH}_{4}{ }^{+}$, definido a partir da menor ou maior concentração do elemento contaminante nas LR do capim, a depender da proporção de $\mathrm{NO}_{3}{ }^{-}$e $\mathrm{NH}_{4}{ }^{+}$em que as plantas foram cultivadas. É possível que o suprimento de $\mathrm{N}$ juntando $\mathrm{NO}_{3}{ }^{-}$ao $\mathrm{NH}_{4}{ }^{+}$tenha favorecido maior absorção de minerais e consequentemente a absorção do excesso de $\mathrm{Cu}$ pelas raízes, o que induziu o transporte de Cu para a parte aérea. Esse efeito foi documentado com o Zn, quando plantas de mostarda indiana (Brassica juncea) foram cultivadas em solução nutritiva contendo proporções de $\mathrm{NO}_{3}{ }^{-} / \mathrm{NH}_{4}{ }^{+}$variando de $100 / 0$ a $50 / 50$ e doses baixa e alta de $\mathrm{Zn}$ de 0 e $4 \mathrm{mg} \mathrm{L}{ }^{-1}$, respectivamente (Hamlin e Barker, 2006).

Valores de referência que indiquem concentrações adequadas de $\mathrm{Cu}$ nas folhas mais novas do Panicum maximum foram estimados na faixa de 4 a $14 \mathrm{mg} \mathrm{kg}^{-1}$ (Werner et al., 1996). Isso indica que as plantas cultivadas com doses de $\mathrm{Cu}$ de 250, 500 e principalmente $1000 \mu \mathrm{mol} \mathrm{L}^{-1}$ estiveram em faixa muito acima da considerada adequada ao crescimento do Panicum maximum, o que sugere a toxidez por excesso desse metal no capim. Indo além, o presente estudo sugere que o capim é tolerante a concentração de $\mathrm{Cu}$ de até $210 \mathrm{mg} \mathrm{kg}^{-1}$ nas LR. Concentrações de $\mathrm{Cu}$ mais elevadas que essas podem ser letais para o capim, devido indicar toxidez letal para o capim. Isso ocorreu com as plantas tratadas com 70/30 de $\mathrm{NO}_{3}{ }^{-} / \mathrm{NH}_{4}{ }^{+}$e doses de $\mathrm{Cu}$ de $1000 \mu \mathrm{mol} \mathrm{L}{ }^{-1}$, que não rebrotaram e foram conduzidas à morte. Gilabel et al. (2014) encontraram valores de concentração de Cu de 74,4 mg kg-1 em função de Cu de 1000 $\mu \mathrm{mol} \mathrm{L}-1$ e enxofre de $4 \mathrm{mmol} \mathrm{L}-1$, mas ressalta-se que os valores podem estar subestimados, haja visto que a solução nutritiva não foi renovada semanalmente, o que provavelmente influenciou os altos teores de $\mathrm{NO}_{3}{ }^{-}$em solução nutritiva e baixa concentração de Cu nas LR do capim. Dessa forma, o presente estudo avança no sentido de mostrar o real limite de concentração de $\mathrm{Cu}$ nas LR do capim recebendo elevadas doses de Cu e consequentemente o real

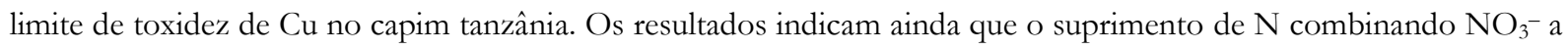
$\mathrm{NH}_{4}{ }^{+}$claramente aumentou o potencial de concentrar $\mathrm{Cu}$ nas LR em situação de excesso desse metal no meio de 
cultivo. No entanto, os limites de tolerância de $\mathrm{Cu}$ pelo capim variaram de acordo com o grau de contaminação do substrato, bem como da proporção de $\mathrm{NO}_{3}{ }^{-} / \mathrm{NH}_{4}{ }^{+}$em que as plantas foram crescidas. Isso porque em situação de ambiente altamente contaminado com $\mathrm{Cu}$, o suprimento de $\mathrm{N}$ combinando $\mathrm{NO}_{3}{ }^{-}$e $\mathrm{NH}_{4}{ }^{+}$pareceu induzir a imobilização do $\mathrm{Cu}$ nas raízes, o que favoreceu a persistência do capim no meio de cultivo. Isso não ocorreu em situações de média disponibilidade de $\mathrm{Cu}$, em que o suprimento com $\mathrm{NO}_{3}{ }^{-} / \mathrm{NH}_{4}{ }^{+}$pareceu ser mais viável do ponto de vista da fitoextração (Hamlin e Barker, 2006), uma vez que possibilitou maior extração de Cu do meio de cultivo sem ocasionar a morte da planta.

A concentração de $\mathrm{NH}_{4}{ }^{+}$nas LR e seu acúmulo na parte aérea do capim tanzânia cultivado principalmente com 70/30 de $\mathrm{NO}_{3}{ }^{-} / \mathrm{NH}_{4}{ }^{+}$, em situação de elevada contaminação por $\mathrm{Cu}$, acompanhou a concentração de $\mathrm{Cu}$ e a atividade da enzima GS nas LR, a qual também esteve em consonância com a menor concentração e menor acúmulo de $\mathrm{NH}_{4}{ }^{+}$nas raízes. Isso confirma que, em situação de toxidez por $\mathrm{Cu}$, plantas tratadas com $\mathrm{NO}_{3}{ }^{-}$e $\mathrm{NH}_{4}{ }^{+}$absorvem $\mathrm{NH}_{4}{ }^{+}$pelas raízes e alteram o fluxo desse íon entre as partes da planta, de modo a concentra-lo excessivamente nas LR. A concentração excessiva de $\mathrm{NH}_{4}{ }^{+}$nas LR do capim provocou indução de alta atividade da GS, o que sugere efeito de sinergia entre os íons $\mathrm{Cu}^{2+}$ e $\mathrm{NH}_{4}{ }^{+}$. Esse efeito sugere que o $\mathrm{NH}_{4}{ }^{+}$também pode atuar na regulação de transportadores de $\mathrm{Cu}$ e vice-versa, assim como o Cu regula a ação de seus próprios transportadores em arroz (Oryza sativa) (Sonoda et al., 2003). Portanto, pelo fato do uso do N exclusivo na forma de $\mathrm{NO}_{3}{ }^{-}$possibilitar pequeno aumento na concentração de $\mathrm{Cu}$ nas LR do capim, sugerindo limitação do transporte do $\mathrm{Cu}$ das raízes para a parte aérea, não há acúmulo excessivo de $\mathrm{NH}_{4}{ }^{+}$na parte aérea induzido pelo excesso de $\mathrm{Cu}$, tal qual ocorreu nas plantas cultivadas com $\mathrm{NO}_{3}{ }^{-}$e $\mathrm{NH}_{4}{ }^{+}$. Isso explica em parte o fato das plantas supridas exclusivamente com $\mathrm{NO}_{3}{ }^{-}$não apresentarem incremento na concentração de $\mathrm{Cu}$ nas $\mathrm{LR}$, nas mais elevadas doses desse metal, uma vez que quando não há concentração excessiva de Cu nas LR a planta não detecta a necessidade de concentrar e acumular $\mathrm{NH}_{4}{ }^{+}$como forma de acúmulo de energia na parte aérea.

$\mathrm{Na}$ parte aérea das plantas cultivadas com $100 \%$ do $\mathrm{N}$ na forma de $\mathrm{NO}_{3}{ }^{-}$combinadas as doses de Cu não ocorreu acúmulo de $\mathrm{NH}_{4}{ }^{+}$, pois esse fenômeno seria dependente da redução do $\mathrm{NO}_{3}{ }^{-}$a $\mathrm{NH}_{4}{ }^{+}$pela ação da atividade

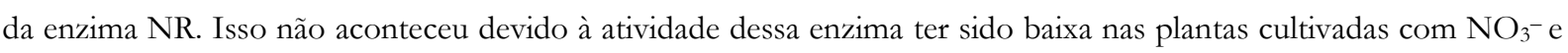
$\mathrm{NH}_{4}{ }^{+}$, o que significa que o aumento no acúmulo de $\mathrm{NH}_{4}{ }^{+}$teria de ser dependente da alta atividade da NR e alto gasto energético. Tal efeito não ocorre, pois em situação de estresse por $\mathrm{Cu}$ a planta parece não priorizar $\mathrm{o}$ investimento energético para reduzir $\mathrm{NO}_{3}{ }^{-}$a $\mathrm{NH}_{4}{ }^{+}$de modo a aumentar o acúmulo de $\mathrm{NH}_{4}{ }^{+}$deliberadamente. Isso porque nessas condições a energia metabólica pode estar sendo utilizada para fins de combate ao estresse, ora induzido pelas altas concentrações de $\mathrm{Cu}$. Portanto, em situação de ausência de $\mathrm{NH}_{4}{ }^{+}$na solução nutritiva não há o estímulo necessário às modificações metabólicas e/ou químicas na planta que conduzam ao aumento do acúmulo de $\mathrm{NH}_{4}{ }^{+}$na parte aérea e também de concentrar $\mathrm{Cu}$ na parte aérea, mostrando mais uma vez o efeito único que o suprimento de formas iônicas de $\mathrm{N}$ exercem na modulação da toxidez de $\mathrm{Cu}$.

$\mathrm{O}$ maior acúmulo de $\mathrm{NH}_{4}^{+}$na parte aérea, em detrimento das raízes, induzido pela concentração excessiva de $\mathrm{Cu}$ nas $\mathrm{LR}$ do capim tanzânia como resposta à exposição a níveis tóxicos de $\mathrm{Cu}$, não tem sido encontrado na literatura. Apesar disso, plantas de arroz após serem submetidas ao excesso de Cu apresentaram aumento da concentração de $\mathrm{NH}_{4}{ }^{+}$nas folhas senescentes (Chen e Kao, 1998). Os autores associaram esses efeitos aos danos oxidativos decorrentes do excesso de $\mathrm{Cu}$ que aumentaram a peroxidação lipídica nas membranas da proteína funcional e ocasionaram menor atividade da enzima GS. A enzima GS é responsável pela assimilação do $\mathrm{NH}_{4}{ }^{+}$, mas em situação de baixíssima atividade não ocorre à assimilação desse íon, situação que conduz ao acúmulo excessivo de $\mathrm{NH}_{4}{ }^{+}$nos tecidos vegetais (Chen e Kao, 1998). Esse efeito não ocorre no capim tanzânia, uma vez que 
o $\mathrm{Cu}$ ao invés de diminuir a atividade da GS, ao contrario, incrementa nas plantas supridas com $\mathrm{NO}_{3}{ }^{-}$e $\mathrm{NH}_{4}{ }^{+}$. Isso porque o $\mathrm{Cu}$ induz alta concentração de $\mathrm{NH}_{4}{ }^{+}$que por sua vez induz alta atividade da GS, como resposta metabólica para assimilar todo o $\mathrm{NH}_{4}{ }^{+}$transportado e, assim, diminuir a possível toxidez desse íon na planta. Dessa forma, é possível que o excesso de $\mathrm{Cu}$, influenciado por altas concentrações de $\mathrm{NH}_{4}{ }^{+}$no meio de cultivo, ative transportadores de $\mathrm{NH}_{4}{ }^{+}$das raízes para a parte aérea como resposta ao estresse e favoreça a concentração desse íon nas LR, bem como a atividade da GS (Ramirez et al., 2011; Sancenón et al., 2003). Esse efeito pode ser a forma que a planta encontrou para garantir $\mathrm{NH}_{4}{ }^{+}$suficiente para garantir a síntese de aminoácidos envolvidos na tolerância de plantas ao estresse por metal (Hayat et al., 2012).

Nas plantas supridas com $\mathrm{N}$ como $\mathrm{NO}_{3}{ }^{-}$a concentração desse íon nas LR aumentou significativamente com as doses de $\mathrm{Cu}$, não ocorrendo para o acúmulo dessa forma de $\mathrm{N}$ na parte aérea. A maior concentração de $\mathrm{NO}_{3}{ }^{-}$ nas LR nas plantas cultivadas com $100 \%$ do $\mathrm{N}$ na forma de $\mathrm{NO}_{3}{ }^{-}$pode ser explicada pelo fato do meio de cultivo conter abundância desse íon, além dessa forma iônica ser preferencialmente absorvida pelas raízes de plantas, especialmente em situação de estresse por metal (Li et al., 2010; Zhang et al., 2014a). Assim, o aumento da concentração de $\mathrm{NO}_{3}{ }^{-}$nas LR sem interferência no acúmulo desse íon na parte aérea parece ser a forma da planta responder à remobilização do $\mathrm{NO}_{3}{ }^{-}$frente à toxidez por $\mathrm{Cu}$, para induzir alta atividade da enzima $\mathrm{NR}$ nas LR. Esses resultados sugerem que, sob toxidez de $\mathrm{Cu}$, o transporte de $\mathrm{NO}_{3}{ }^{-}$para as $\mathrm{LR}$ foi maior do que a capacidade que a folha teve em reduzir o $\mathrm{NO}_{3}{ }^{-}$a $\mathrm{NH}_{4}{ }^{+}$, mesmo a enzima atuando em níveis altos, que acabou por não refletir no maior acúmulo de $\mathrm{NO}_{3}{ }^{-}$. Portanto, quando a concentração de $\mathrm{NO}_{3}{ }^{-}$nas $\mathrm{LR}$ foi maior nas doses mais elevadas de $\mathrm{Cu}$, a atividade da enzima NR também foi maior, significando que o aumento da concentração de $\mathrm{NO}_{3}{ }^{-}$na $\mathrm{LR}$ induziu a elevada atividade da enzima NR. Ressalta-se que a atividade da enzima NR é ativada e induzida pela presença de $\mathrm{NO}_{3}{ }^{-}$no meio de cultivo (Darnell e Hiss, 2006), tal qual a GS é induzida pela presença de $\mathrm{NH}_{4}{ }^{+}$(Thomsen et al., 2014), garantindo a assimilação do $\mathrm{N}$ necessária nas condições com suprimento de $\mathrm{N}$ na forma de $\mathrm{NO}_{3}{ }^{-}$ou combinando $\mathrm{NO}_{3}^{-}$ao $\mathrm{NH}_{4}^{+}$, em condição de toxidez por $\mathrm{Cu}$.

Valores de referência que indicam a concentração de $\mathrm{N}$ total nas LR do capim tanzânia adequada ao crescimento da planta foram relatados por Silveira e Monteiro (2010). Para esses autores, em situação de alto suprimento com $\mathrm{N}$ de até $30 \mathrm{mmol} \mathrm{L}-1$, o capim tanzânia elevou a concentração de $\mathrm{N}$ total nas LR até $20 \mathrm{~g} \mathrm{~kg}^{-1}$, valores estes associados à adequada nutrição com N (Silveira e Monteiro, 2010). Portanto, o capim tanzânia cultivado sob proporções de $\mathrm{NO}_{3}{ }^{-} / \mathrm{NH}_{4}{ }^{+}$no primeiro corte, no presente estudo, esteve adequadamente nutrido com $\mathrm{N}$, haja visto que os valores de concentração de $\mathrm{N}$ total nas LR estiveram próximo ou acima da faixa constatada por Silveira e Monteiro (2010). As doses de Cu não interferiram na concentração de $\mathrm{N}$ total nas LR, o que significa dizer que o capim tanzânia possui mecanismos de tolerar alterações negativas na concentração desse nutriente nas LR, em função da toxidez por $\mathrm{Cu}$, de modo a garantir adequada concentração de $\mathrm{N}$ nas LR. Apesar disso, no primeiro crescimento, a toxidez de $\mathrm{Cu}$ afetou fortemente o acúmulo de $\mathrm{N}$ total, especialmente no capim tanzânia suprido com $70 / 30$ de $\mathrm{NO}_{3}-/ \mathrm{NH}_{4}{ }^{+}$. Confrontando esses resultados com os constatados para a concentração nas LR e acúmulo na parte aérea dos íons $\mathrm{NO}_{3}{ }^{-}$e $\mathrm{NH}_{4}{ }^{+}$, entende-se que os menores valores de acúmulo de $\mathrm{N}$ total nas plantas podem ser decorrentes dos efeitos negativos do $\mathrm{Cu}$ em diminuir a produção de massa seca das plantas, o que acabou por diminuir também o acúmulo de $\mathrm{N}$ na biomassa.

No segundo corte do capim tanzânia, os valores de concentração de $\mathrm{N}$ total atingiram patamares mais elevados que os verificados no primeiro crescimento, especialmente na dose de $\mathrm{Cu}$ de $500 \mu \mathrm{mol} \mathrm{L}{ }^{-1}$. Esse efeito é associado à resposta de defesa da planta, que por sofrer toxidez de $\mathrm{Cu}$ severa ao final do primeiro crescimento, estimulou alta atividade da NR de forma a garantir a aquisição de N para a rebrotação. Nas raízes do capim tanzânia, 
a concentração de $\mathrm{N}$ total foi afetada pelo $\mathrm{Cu}$ somente na proporção $70 / 30$ de $\mathrm{NO}_{3}{ }^{-} / \mathrm{NH}_{4}{ }^{+}$. Isso refletiu em menor aquisição de $\mathrm{N}$ pelas plantas, evidenciado pelo acúmulo de $\mathrm{N}$ total nas raízes, os quais foram menores independentes das proporções de $\mathrm{NO}_{3}{ }^{-} / \mathrm{NH}_{4}{ }^{+}$, mesmo ocorrendo incremento do acúmulo de $\mathrm{NO}_{3}{ }^{-}$nas raízes. Isso significa que os menores valores de acúmulo de $\mathrm{N}$ total podem estar associados a outras formas de $\mathrm{N}$ na planta, como aminoácidos e proteínas, os quais podem ter sido afetados negativamente pela toxidez de Cu nas plantas (Weber et al., 1991).

No sistema radicular, a maior concentração e acúmulo de $\mathrm{NO}_{3}{ }^{-}$em função das doses de $\mathrm{Cu}$ foram evidentes e marcadamente maiores nas plantas supridas com $\mathrm{N}$ na forma de $\mathrm{NO}_{3}{ }^{-}$. Esse efeito foi de extrema relevância para avaliar as respostas das plantas ao estresse abiótico, uma vez que em situação de excesso do metal, plantas modificam o fluxo normal de $\mathrm{NO}_{3}{ }^{-}$de modo a estocar esse íon em órgãos fortemente afetado pelo metais, caso das raízes (Li et al., 2010). Esse fenômeno ocorre via mecanismos de sinalização que envolvem a produção de etileno e ácido jasmônico, os quais ativam a ação de transportadores de nitrato NRT 1.5 e NRT 1.8 que redirecionam o acúmulo de $\mathrm{NO}_{3}{ }^{-}$para as raízes. Isso garante a estocagem de energia nesse órgão, o que media a tolerância de plantas a metais pesados (Li et al., 2010; Zhang et al., 2014a). O processo de alocação de $\mathrm{NO}_{3}{ }^{-}$nas raízes em situação de estresse por metal é conhecido como SINAR (Stress-Initiated Nitrate Allocation to Roots) e o presente trabalho avança no sentido de mostrar que o suprimento com $\mathrm{N}$ na forma $\mathrm{NO}_{3}^{-}$pode induzir esse mecanismo de tolerância no capim tanzânia, favorecendo a persistência da planta em meio de cultivo altamente contaminado com Cu. Apesar disso, tal efeito não ocorre nas plantas de capim supridas com proporções de 70/30 e 50/50 de $\mathrm{NO}_{3}{ }^{-} / \mathrm{NH}_{4}{ }^{+}$, uma

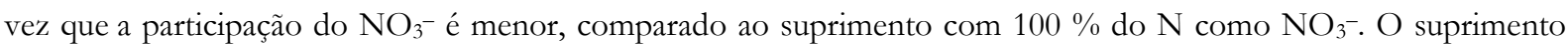
com $\mathrm{N}$ como $\mathrm{NO}_{3}{ }^{-}$mostrou ser de fundamental para que o efeito SINAR ocorra no capim tanzânia. Dessa forma, pareceu ser a abundância de $\mathrm{NO}_{3}{ }^{-}$no meio de cultivo a responsável pela ativação desse processo.

Uma das causas da toxidez por $\mathrm{Cu}$ é seu efeito negativo no metabolismo do $\mathrm{N}$, resultando em baixa atividade da enzima NR (Xiong et al., 2006). O efeito negativo das doses de Cu na atividade da enzima NR foi comprovado no primeiro crescimento do capim, mas apenas quando a gramínea foi cultivada na proporção 70/30 de $\mathrm{NO}_{3}{ }^{-} / \mathrm{NH}_{4}{ }^{+}$. Isso pode ser justificado pelo fato dessa proporção ter promovido maior concentração do metal nas LR e menor concentração de $\mathrm{NO}_{3}{ }^{-}$nessas folhas. A alta concentração de $\mathrm{Cu}$ nas $\mathrm{LR}$ proporciona a inibição da atividade da enzima NR em função dos possíveis danos causados pelo excesso de Cu nas proteínas funcionais (Zhang et al., 2014b). Além disso, a alta concentração de $\mathrm{Cu}$ nas LR nas plantas cultivadas com $\mathrm{NO}_{3}^{-}$e $\mathrm{NH}_{4}^{+}$ induziu baixas concentrações de $\mathrm{NO}_{3}{ }^{-}$nas LR, que impossibilitaram desse efeito contribuir como indutor de alta atividade da NR. No segundo crescimento, a alta atividade da enzima NR nas LR, verificada na proporção 70/30 de $\mathrm{NO}_{3}{ }^{-} / \mathrm{NH}_{4}{ }^{+}$combinada às elevadas doses de $\mathrm{Cu}$, sugere que a energia obtida pela absorção do $\mathrm{NH}_{4}{ }^{+}$foi deslocada para a planta ativar o sistema de defesa metabólica necessária a sua sobrevivência. Isso ocorreu na tentativa da planta em recuperar parte dos danos que o $\mathrm{Cu}$ exerceu ao final do primeiro crescimento, garantindo a assimilação de $\mathrm{N}$ necessária para a rebrotação do capim em situação de toxidez de Cu. É sabido que o excesso de Cu no tecido vegetal se liga aos resíduos de cisteína do citocromo do complexo enzimático da NR, reduzindo ou até mesmo inibindo a atividade dessa enzima (Xiong et al., 2006), efeito que explica os menores valores de atividade da NR nas plantas que apresentaram maior concentração de Cu nas LR. Além disso, o excesso de Cu pode aumentar a síntese das espécies reativas de oxigênio, causando peroxidação lipídica nas proteínas e diminuindo sua concentração nas folhas, causando assim diminuição na atividade da própria NR (Vajpayee et al., 2005). Zhang et al. (2014b) verificaram que doses de $\mathrm{Cu}$ em meio de cultivo in vitro contendo raízes destacadas de Luffa cylindrica resultaram em menor atividade da NR, bem como de várias outras enzimas relacionadas à assimilação de $\mathrm{N}$. 
$\mathrm{Na}$ literatura encontra-se que doses tóxicas de $\mathrm{Cu}$ exercem baixa atividade da enzima GS (Xiong et al., 2006; Zhang et al., 2014b). No entanto, esse efeito não foi constado no capim tanzânia, nem mesmo nas mais altas doses de $\mathrm{Cu}$ associada ao suprimento de $100 \%$ do $\mathrm{N}$ na forma de $\mathrm{NO}_{3}{ }^{-}$, proporção de $\mathrm{NO}_{3}{ }^{-} / \mathrm{NH}_{4}{ }^{+}$que favoreceu baixa concentração de $\mathrm{NH}_{4}{ }^{+}$nas LR. Isso sugere que a enzima GS no capim tanzânia é resistente ao excesso de Cu e indica ser enzima-chave para assimilação de $\mathrm{N}$ em condição de estresse por Cu. Talvez por isso o capim tanzânia também consiga suportar elevadas concentrações de Cu nas LR, uma vez que a alta atividade da enzima GS associada à alta concentração de $\mathrm{NH}_{4}{ }^{+}$favoreça a assimilação de $\mathrm{N}$ para suportar o estresse por esse metal. Contudo, esse efeito ocorre até certo limite de concentração de $\mathrm{Cu}$, que parece ser pré-determinado pela genética da planta. A enzima GS também não foi afetada pela combinação dos fatores estudados em termos de segundo corte do capim, o que significa que a atividade da GS foi preservada mesmo em condição de toxidez residual por Cu. Esse efeito sustentou a assimilação de $\mathrm{N}$ necessária tanto no primeiro crescimento, quanto na rebrotação do capim, para garantir a permanência da planta no meio de cultivo mesmo em situação de alta concentração de Cu em sua biomassa. Dessa forma, acredita-se que a elevada atividade da enzima GS, por ser compatível a concentração de $\mathrm{NH}_{4}{ }^{+}$e de $\mathrm{Cu}$ nas LR, pode ser indicativo de que o capim concentra $\mathrm{NH}_{4}^{+}$na tentativa de aumentar a síntese de glutamato. A alta síntese de glutamato pode garantir alta síntese de outro aminoácido antioxidante osmorregulador, a prolina (Paulose et al., 2013), que tem função importante na desintoxicação direta das espécies reativas de oxigênio, amplamente relacionada à toxidez por metal (Hayat et al., 2012).

As elevadas concentrações de $\mathrm{Cu}$ nas raízes do capim tanzânia exposto às doses tóxicas de $\mathrm{Cu}$, especialmente nas plantas tratadas com $100 \%$ do $\mathrm{N}$ na forma de $\mathrm{NO}_{3}{ }^{-}$, apresentaram padrão diferente das demais proporções de $\mathrm{NO}_{3}-/ \mathrm{NH}_{4}{ }^{+}$estudadas. Isso porque na proporção $100 / 0$ de $\mathrm{NO}_{3}^{-} / \mathrm{NH}_{4}{ }^{+}$a concentração de $\mathrm{Cu}$ nas raízes foi incrementada a valores elevados em cada dose de $\mathrm{Cu}$, o que não ocorreu na parte aérea dessas plantas, indicando que ao invés da planta transportar o excesso de $\mathrm{Cu}$ para a parte aérea, acabou imobilizando o metal nas raízes. Esse efeito sugere que a toxidez por $\mathrm{Cu}$ nas plantas supridas com $\mathrm{N}$ na forma de $\mathrm{NO}_{3}{ }^{-}$, especialmente no segundo corte, foram decorrentes principalmente dos prejuízos causados ao sistema radicular. Isso ocorreu de forma diferente nas plantas cultivadas com $70 / 30$ e 50/50 de $\mathrm{NO}_{3}{ }^{-} / \mathrm{NH}_{4}{ }^{+}$, uma vez que apresentaram os efeitos sugerem danos tanto na parte aérea, quanto nas raízes. $\mathrm{Na}$ dose de $\mathrm{Cu}$ de 250 e $500 \mu \mathrm{mol} \mathrm{L}{ }^{-1}$ combinada à proporção $70 / 30$ de $\mathrm{NO}_{3}{ }^{-} / \mathrm{NH}_{4}{ }^{+}$a elevada concentração de $\mathrm{Cu}$ nas $\mathrm{LR}$ sugere que o $\mathrm{Cu}$ foi transportado das raízes para a parte aérea, o que explica a baixa concentração do metal nas raízes do capim exposto ao Cu de 250 e $500 \mu \mathrm{mol} \mathrm{L}{ }^{-1}$. No entanto, pelo fato da dose de $\mathrm{Cu}$ de $1000 \mu \mathrm{mol} \mathrm{L}{ }^{-1}$ ser excessivamente alta nas plantas supridas com 70/30 de $\mathrm{NO}_{3}^{-} / \mathrm{NH}_{4}{ }^{+}$, acabou ocorrendo maior concentração desse metal tanto na parte aérea quanto nas raízes do capim. Isso aconteceu porque as concentrações de $\mathrm{Cu}$ nas LR atingiram a faixa letal, determinada pela genética da planta, conduzindo a não rebrotação e morte do capim. É possível que o sistema radicular do capim tanzânia, por estar em contato direto com o excesso de Cu na solução nutritiva, precisou desenvolver diversas estratégias de alteração de transporte de minerais para tolerar o excesso de $\mathrm{Cu}$ nas raízes, evidenciado principalmente pelas alterações dos transportes de $\mathrm{NO}_{3}{ }^{-}, \mathrm{NH}_{4}{ }^{+} \mathrm{e}$ $\mathrm{Cu}$. Tais estratégias parecem envolver também a imobilização do excesso de $\mathrm{Cu}$ nas raízes, especialmente em áreas conhecidas por acumular $\mathrm{Cu}$, como as paredes celulares de plantas (Xu et al., 2013).

Hamlin e Barker (2006) verificaram que a proporção 90/10 de $\mathrm{NO}_{3}{ }^{-} / \mathrm{NH}_{4}{ }^{+}$resultou menor concentração de Zn nas raízes de plantas de mostarda indiana, cultivadas sob alta dose de $\mathrm{Zn}\left(4 \mathrm{mg} \mathrm{L}^{-1}\right)$. Nas plantas cultivadas com 100\% do $\mathrm{N}$ na forma de $\mathrm{NO}_{3}{ }^{-}$ocorreu maior concentração de $\mathrm{Zn}$ nas raízes, resultados opostos ao do presente estudo. Os autores associaram tais resultados ao efeito do $\mathrm{NO}_{3}{ }^{-}$em estimular a absorção de cátions pela planta, o que não pode ser associado ao presente estudo, uma vez que a maior absorção de cátion $\left(\mathrm{NH}_{4}^{+}\right)$promoveu maior 
absorção de outro cátion $\left(\mathrm{Cu}^{2+}\right)$ e/ou vice-versa. Essas diferenças provavelmente ocorreram em decorrência das espécies de plantas que são diferentes e do metal Zn em foco, que possivelmente apresenta mecanismos de absorção diferente do $\mathrm{Cu}$. Isso mostra as respostas entre espécies vegetais, assim como sua associação a outros metais, que apesar de similares, não podem ter efeito generalizado, especialmente sob influencia de proporções de $\mathrm{NO}_{3}^{-} / \mathrm{NH}_{4}{ }^{+}$.

Os atributos morfogênicos e a produtividade de uma dada espécie vegetal, condicionada à toxidez por excesso de $\mathrm{Cu}$ no meio de cultivo, são determinantes para avaliar a viabilidade do processo de recuperação do ambiente contaminado por $\mathrm{Cu}$. Isso porque a elevada biomassa produzida nesses ambientes podem indicar alta fitoextração de metais, bem como a persistência do capim no meio de cultivo. Na escala de efeitos deletérios da toxidez por $\mathrm{Cu}$, as variações negativas nos atributos morfogênicos e produtivos são os últimos processos decorrentes da alteração da homeostase nutricional e metabólica promovida pela toxidez do metal. Nesse sentido, a capacidade de produzir folhas, perfilhos e massa seca que o capim tanzânia possui, em situação de estresse por Cu, também podem indicar a tolerância do capim a esse metal. Os efeitos de alívio de toxidez por $\mathrm{Cu}$ na nutrição mineral, crescimento e produção do capim tanzânia, no primeiro corte, suprido especialmente com $\mathrm{N}$ na forma de $\mathrm{NO}_{3}{ }^{-}$, impossibilitou ou amenizou alterações na homeostase nutricional e metabólica. Esse efeito também impossibilitou ou minimizou variações negativas na produção de massa seca e no crescimento dessas plantas, em ambiente contaminado com $\mathrm{Cu}$. Nesse contexto, mesmo que a proporção 100/0 de $\mathrm{NO}_{3}{ }^{-} / \mathrm{NH}_{4}{ }^{+}$não tenha favorecido a maior concentração de $\mathrm{Cu}$ nas $\mathrm{LR}$ mesmo nas mais elevadas doses de $\mathrm{Cu}$, tal efeito pode ser benéfico. Isso porque o $\mathrm{N}$ fornecido exclusivamente na forma de $\mathrm{NO}_{3}{ }^{-}$amenizou significativamente os danos do excesso de $\mathrm{Cu}$ na produção de massa seca. Isso ocorreu de forma diferente das plantas cultivadas com suprimento combinando $\mathrm{NO}_{3}^{-}$ao $\mathrm{NH}_{4}{ }^{+} \mathrm{e}$ elevadas doses de $\mathrm{Cu}$, uma vez que possibilitaram maior concentração de $\mathrm{Cu}$ nas $\mathrm{LR}$ e com isso a diminuição da produção de massa seca da parte aérea do capim tanzânia. Apesar disso, efeitos de alívio de estresse não puderam ser comprovados para o número de folhas e de perfilhos no primeiro crescimento, uma vez que o tempo de exposição não foi longo o suficiente para promover senescência das folhas e morte dos perfilhos.

No segundo crescimento, período em que se verificou que plantas tratadas com $\mathrm{N}$ na forma de $\mathrm{NO}_{3}{ }^{-}$ apresentaram melhores condições de rebrotação, a produção de massa seca, o número de folhas e o número de perfilhos foram afetadas pela combinação dos fatores em estudo. Isso porque as plantas tratadas com $\mathrm{N}$ na forma de $\mathrm{NO}_{3}{ }^{-}$puderam concentrar menores quantidades de $\mathrm{Cu}$ na biomassa, sugerindo menores danos causados pelo $\mathrm{Cu}$ na parte aérea. Nesse sentido, entende-se que além da tolerância natural do capim tanzânia ao excesso de $\mathrm{Cu}$, proporções de $\mathrm{NO}_{3}-\mathrm{NH}_{4}{ }^{+}$podem se ajustar em cada nível de contaminação pelo metal, favorecendo a permanência do capim nessas condições estressantes. Gilabel et al. (2014) também verificaram que o capim tanzânia cultivado em casa de vegetação com solução nutritiva contendo doses de $\mathrm{Cu}$ até $1000 \mu \mathrm{mol} \mathrm{L}{ }^{-1}$, sem variação de doses de $\mathrm{N}$, apresentou menor produção de massa seca aérea e menor número de folhas e de perfilhos, mas em estudo que não testou as proporções de $\mathrm{NO}_{3}{ }^{-} / \mathrm{NH}_{4}{ }^{+}$. O excesso de $\mathrm{Cu}$ afeta negativamente a fotossíntese das plantas, assim como o seu teor proteico, contribuindo diretamente para a perda de produção de massa das plantas em situação de toxidez de $\mathrm{Cu}$ (Bazihizina et al., 2015)

O teor de clorofila, estimado por meio de unidades SPAD, mostrou efeitos de alivio de toxidez promovido pelo suprimento de $\mathrm{N}$ exclusivo na forma de $\mathrm{NO}_{3}{ }^{-}$em condição de elevada contaminação de Cu. Esse efeito pode ser explicado pelo fato do $\mathrm{N}$ na forma de $\mathrm{NO}_{3}{ }^{-}$ter impedido o aumento excessivo da concentração de $\mathrm{Cu}$ nas LR do capim e, com isso, diminuído os danos oxidativos induzidos pelo Cu na clorofila das plantas (Xu et al., 2013). Esses resultados confirmam que a possível limitação do transporte do excesso de Cu das raízes para a parte aérea pode ter ocasionado de fato a minimização dos danos oxidativos do $\mathrm{Cu}$ na clorofila das plantas, uma vez que o 
$\mathrm{Cu}$ em excesso conduz menor teor total de clorofila, assim como menor teor de clorofila a, de clorofila b e de carotenoides (Bazihizina et al., 2015). Tal efeito está em consonância com a verificação de menor valor SPAD nas plantas tratadas com 70/30 e 50/50 de $\mathrm{NO}_{3}{ }^{-} / \mathrm{NH}_{4}{ }^{+}$e doses tóxicas de $\mathrm{Cu}$ de 500 e $1000 \mu \mathrm{mol} \mathrm{L}-1$, em comparação às plantas tratadas com $\mathrm{N}$ na forma de $\mathrm{NO}_{3}{ }^{-}$. Isso também explica parte do efeito negativo do $\mathrm{Cu}$ em diminuir a produção de massa seca do capim, uma vez que plantas com menores teores de clorofila apresentam menor potencial de crescimento, comparado às plantas com teores adequados de clorofila. Portanto, o papel que o suprimento com $\mathrm{N}$ exclusivo na forma de $\mathrm{NO}_{3}{ }^{-}$assume no cultivo de plantas de capim tanzânia em condição de alta contaminação por Cu parece envolver também a alteração do teor de clorofila, com impacto direto na rebrotação do capim, mesmo em condição de alta contaminação com $\mathrm{Cu}$.

\subsection{Conclusão}

As desordens causadas pela toxidez de $\mathrm{Cu}$ se refletem principalmente em modificações no transporte de $\mathrm{NO}_{3}^{-}$e $\mathrm{NH}_{4}^{+}$entre a parte aérea e as raízes, que modificam também o padrão de atividade das enzimas NR e GS. Nesse contexto, as atividades dessas enzimas são modificadas em função tanto das doses de Cu quanto das proporções de $\mathrm{NO}_{3}{ }^{-} / \mathrm{NH}_{4}{ }^{+}$. A toxidez por Cu conduz a menor produção de massa seca, menor crescimento e consequentemente menor persistência do capim no meio de cultivo, especialmente nas plantas que recebem $\mathrm{NO}_{3}^{-} \mathrm{e}$ $\mathrm{NH}_{4}{ }^{+}$como fonte de $\mathrm{N}$, pois são capazes de absorver mais $\mathrm{Cu}$. O emprego do $\mathrm{N}$ na forma de $\mathrm{NO}_{3}-$ é estratégia com maior potencial de uso em ambientes altamente contaminados com $\mathrm{Cu}$, uma vez que limita a concentração excessiva de Cu nas LR e por isso garante condição de homeostase nutricional e metabólica as plantas de capim tanzânia. Em contrapartida, o uso combinando $\mathrm{NO}_{3}{ }^{-}$ao $\mathrm{NH}_{4}{ }^{+}$promove maior contração de $\mathrm{Cu}$ nas LR, efeito desejável do ponto de vista da fitorremediação, mas que possibilita as alterações metabólicas e nutricionais que desencadeiam em baixa produção de massa e menor persistência da planta no meio de cultivo. Dessa forma, o uso combinando $\mathrm{NO}_{3}^{-}$ao $\mathrm{NH}_{4}{ }^{+}$é estratégia com maior potencial de uso em ambientes moderadamente contaminados com $\mathrm{Cu}$, uma vez que as desordens nutricionais e metabólicas nessas condições não são letais. Dessa forma, conclui-se que as variações de proporções de $\mathrm{NO}_{3}{ }^{-} / \mathrm{NH}_{4}{ }^{+}$alteram os efeitos negativos da toxidez de $\mathrm{Cu}$ nos atributos nutricionais e produtivos do capim tanzânia.

\section{Referências}

Bazihizina, N., Colzi, I., Giorni, E., Mancuso, S., Gonnelli, C., 2015. Photosynthesizing on metal excess: Copper differently induced changes in various photosynthetic parameters in copper tolerant and sensitive Silene paradoxa L. populations. Plant Sci. 232, 67-76. doi:10.1016/j.plantsci.2014.12.015

Chen, L.M., Kao, C.H., 1998. Relationship between ammonium accumulation and senescence of detached rice leaves caused by excess copper. Plant Soil 200, 169-173. doi:10.1023/A:1004369518777

Costa, M.C.G., Cunha, I.M.L., Jorge, L.A.C., Araújo, I.C.S., 2014. Public-domain software for root image analysis. Rev. Bras. Ciência do Solo 38, 1359-1366.

Darnell, R.L., Hiss, S.A., 2006. Uptake and assimilation of nitrate and iron in two vaccinium species as affected by external nitrate concentration. J. Am. Soc. Hortic. Sci. 131, 5-10.

Elliott, W.H., 1952. Isolation of glutamine synthetase and glutamotransferase from green peas. J. Biol. Chem. 201, 661-672. 
Epstein, E., Bloom, A.J., 2006. Nutrição mineral de plantas. 3a. Ed., Editora Planta: Londrina, 403 p.

Gilabel, A.P., Nogueirol, R.C., Garbo, A.I., Monteiro, F.A., 2014. The role of sulfur in increasing guinea grass tolerance of copper phytotoxicity. Water. Air. Soil Pollut. 225, 1806-1816. doi:10.1007/s11270-013-1806-8

Hamlin, R.L., Barker, A. V, 2006. Influence of ammonium and nitrate nutrition on plant growth and zinc accumulation by indian mustard. J. Plant Nutr. 29, 1523-1541. doi:10.1080/01904160600837709

Hayat, S., Hayat, Q., Alyemeni, M.N., Wani, A.S., Pichtel, J., Ahmad, A., 2012. Role of proline under changing environments: a review. Plant Signal. Behav. 7, 1456-1466. doi:10.4161/psb.21949

Heldt, H.W., 2005. Plant biochemistry. 3 ed. Elsevier: Amsterdam, 630 p.

Hoagland, D.R., Arnon, D.I., 1950. The water culture method for growing plants without soils. Berkeley: California Agricultural Experimental Station, 347 p.

Lavres Junior, J., Santos Junior, J.D.G., Monteiro, F.A., 2010. Nitrate reductase activity and spad readings in leaf tissues of guinea grass submitted to nitrogen and potassium rates. Rev. Bras. Ciência do Solo 34, 801-809. doi:10.1590/S0100-06832010000300022

Li, J.-Y., Fu, Y.-L., Pike, S.M., Bao, J., Tian, W., Zhang, Y., Chen, C.-Z., Zhang, Y., Li, H.-M., Huang, J., Li, L.-G., Schroeder, J.I., Gassmann, W., Gong, J.-M., 2010. The Arabidopsis nitrate transporter NRT1.8 functions in nitrate removal from the xylem sap and mediates cadmium tolerance. Plant Cell 22, 1633-1646. doi:10.1105/tpc.110.075242

Rabêlo, F.H.S., Azevedo, R.A., Monteiro, F.A., 2016. Proper supply of S increases GSH synthesis in the establishment and reduces tiller mortality during the regrowth of Tanzania guinea grass used for Cd phytoextraction. J. Soils Sediments. 1, 1-10. doi:10.1007/s11368-016-1429-y

Ramirez, C.O., Mora, S.I., Trejo, J., Pantoja, O., 2011. PvAMT1;1, a highly selective ammonium transporter that functions as $\mathrm{H}^{+} / \mathrm{NH}_{4}{ }^{+}$symporter. J. Biol. Chem. 286, 31113-31122. doi:10.1074/jbc.M111.261693

Sancenón, V., Puig, S., Mira, H., Thiele, D.J., Peñarrubia, L., 2003. Identification of a copper transporter family in Arabidopsis thaliana. Plant Mol. Biol. 51, 577-587. doi:10.1023/A:1022345507112

Santos, J.H.S., De Bona, F.D., Monteiro, F.A., 2013. Growth and productive responses of tropical grass Panicum maximum to nitrate and ammonium supply. Rev. Bras. Zootec. 42, 622-628. doi:10.1590/S151635982013000900003

Sarruge, J.R., Haag, H.P., 1974. Análises químicas em plantas. ESALQ: Piracicaba, 56 p.

SAS Institute. SAS/STAT: Qualification Tools user's guide, version 9.2 Cary, 2008.

Silveira, C.P., Monteiro, F.A., 2010. Macronutrients concentrations in Tanzania guinea grass diagnostic leaves supplied with nitrogen and calcium rates. Rev. Bras. Zootec. 39, 736-745. doi:10.1590/S151635982010000400006

Silveira, C.P., Monteiro, F.A., 2011. Influence of nitrogen and calcium fertilizations on morphological and productive characteristics of tanzania guineagrass roots grown in nutrient solution. Rev. Bras. Zootec. 40, 47-52. doi:10.1590/S1516-35982011000100007

Sonoda, Y., Ikeda, A., Saiki, S., Yamaya, T., 2003. Distinct expression and function of three ammonium transporter genes (OsAMT1;1 - 1;3 ) in rice. Plant Cell Physiol. 44, 726-734. doi:10.1093/pcp/pcg083

Tedesco, M.J., Volkweiss, S.J., Bohnen, H., 1985. Análise de solo, planta e outros materiais. UFRGS, Departamento de Solos: Porto Alegre, 188 p.

Thomsen, H.C., Eriksson, D., Møller, I.S., Schjoerring, J.K., 2014. Cytosolic glutamine synthetase: A target for improvement of crop nitrogen use efficiency? Trends Plant Sci. 19, 656-663. doi:10.1016/j.tplants.2014.06.002 
Vajpayee, P., Rai, U.N., Ali, M.B., Tripathi, R.D., Kumar, A., Singh, S.N., 2005. Possible involvement of oxidative stress in copper induced inhibition of nitrate reductase activity in Vallisneria spiralis L. Bull. Environ. Contam. Toxicol. 74, 745-754. doi:10.1007/s00128-005-0645-8

Wacker, T., Garcia-celma, J.J., Lewe, P., Andrade, S.L.A., 2014. Direct observation of electrogenic NH4+ transport in ammonium transport (Amt) proteins. Proc. Natl. Acad. Sci. 111, 9995-10000. doi:10.1073/pnas.1406409111

Wang, Y.Y., Hsu, P.K., Tsay, Y.F., 2012. Uptake, allocation and signaling of nitrate. Trends Plant Sci. 17, $458-467$. doi:10.1016/j.tplants.2012.04.006

Weber, M.B., Schat, H., Maarel, W.M.T.B.-V.D., 1991. The effect of copper toxicity on the contents of nitrogen compounds in Silene vulgaris (Moench) Garcke. Plant Soil. 133, 101-109. doi:10.1007/BF00011904

Werner, J.C., Paulino, V.T., Cantarella, H., Andrade, N.O., Quaggio, J.A., 1996. Forrageiras. In: Van Raij, B., Cantarella, H., Quaggio, J.A., Furlani, A.M.C. (Ed.). Recomendações de adubação e calagem para o Estado de São Paulo. 2 ed. Instituto Agronômico de Campinas \& Fundação IAC: Campinas, p. 263-273.

Xiong, Z.T., Liu, C., Geng, B., 2006. Phytotoxic effects of copper on nitrogen metabolism and plant growth in Brassica pekinensis Rupr. Ecotoxicol. Environ. Saf. 64, 273-280. doi:10.1016/j.ecoenv.2006.02.003

Xu, Q., Qiu, H., Chu, W., Fu, Y., Cai, S., Min, H., Sha, S., 2013. Copper ultrastructural localization, subcellular distribution, and phytotoxicity in Hydrilla verticillata (L.f.). Royle. Environ. Sci. Pollut. Res. 20, 8672-8679. doi:10.1007/s11356-013-1828-1

Zhang, G.-B., Yi, H.-Y., Gong, J.-M., 2014a. The Arabidopsis Ethylene/jasmonic acid-NRT signaling module coordinates nitrate reallocation and the trade-off between growth and environmental adaptation. Plant Cell. 26, 3984-3998. doi:10.1105/tpc.114.129296

Zhang, L., He, X., Chen, M., An, R., An, X., Li, J., 2014b. Responses of nitrogen metabolism to copper stress in Luffa cylindrica roots. J. Soil Sci. Plant Nutr. 14, 616-624. 


\section{FORNECIMENTO DE NITRATO E AMÔNIO AUMENTA FITOEXTRAÇÃO DE COBRE E INDUZ ATIVIDADE DA SUPERÓXIDO DISMUTASE E SÍNTESE DE PROLINA NO CAPIM TANZÂNIA}

\section{Resumo}

O nitrogênio $(\mathrm{N})$ é amplamente relacionado ao alívio da toxidez de $\mathrm{Cu}$ nas plantas e incremento da fitoextração de metal. A toxidez de $\mathrm{Cu}$ causa estresse oxidativo, alterando o metabolismo e a fotossíntese das plantas, mas não há estudos associando proporções de nitrato e amônio $\left(\mathrm{NO}_{3}{ }^{-} / \mathrm{NH}_{4}{ }^{+}\right)$no alívio dessa toxidez. Objetivou-se avaliar o efeito de doses de $\mathrm{Cu}$ no acúmulo desse metal nas partes do Panicum maximum cv. Tanzânia e a consequência desse acúmulo nos indicadores de estresse oxidativo, fotossintéticos e antioxidantes, elucidando o papel de proporções de $\mathrm{NO}_{3}{ }^{-} / \mathrm{NH}_{4}{ }^{+}$nas modificações desses atributos. O delineamento experimental foi de blocos ao acaso em arranjo fatorial $3 \times 4$, com três repetições. Os fatores foram três proporções de $\mathrm{NO}_{3}{ }^{-} / \mathrm{NH}_{4}{ }^{+}$ $\left(100 / 0 ; 70 / 30\right.$ e 50/50) e quatro doses de $\mathrm{Cu}\left(0,3 ; 250 ; 500\right.$ e $\left.1000 \mu \mathrm{mol} \mathrm{L}{ }^{-1}\right)$ em solução nutritiva. Foram avaliados dois períodos de crescimento das plantas, sendo o primeiro realizado com exposição ao $\mathrm{Cu}$ e o segundo sem exposição ao $\mathrm{Cu}$. $\mathrm{O}$ maior acúmulo de $\mathrm{Cu}$ na parte aérea foi verificado nas plantas supridas com 70/30 de $\mathrm{NO}_{3}{ }^{-} / \mathrm{NH}_{4}{ }^{+}$e $\mathrm{Cu}$ de $1000 \mu \mathrm{mol} \mathrm{L}{ }^{-1}$ no primeiro corte do capim. Essas plantas também apresentaram maior concentração de prolina na parte aérea, assim como maior atividade da superóxido dismutase (SOD) nas raízes. Nas plantas supridas com $\mathrm{N}$ na forma de $\mathrm{NO}_{3}{ }^{-} \mathrm{e}$ $\mathrm{Cu}$ de $1000 \mu \mathrm{mol} \mathrm{L}{ }^{-1}$ ocorreu menor acúmulo de $\mathrm{Cu}$ na parte aérea e elevado acúmulo de $\mathrm{Cu}$ nas raízes. Nessas plantas, a concentração de prolina na parte aérea e a atividade da enzima SOD nas raízes foram menores, mas a condutância estomática na dose de $\mathrm{Cu}$ de $500 \mu \mathrm{mol} \mathrm{L}{ }^{-1}$ foi maior do que nas plantas cultivadas com $70 / 30$ de $\mathrm{NO}_{3}{ }^{-} / \mathrm{NH}_{4}{ }^{+}$. A concentração de malondialdeído (MDA) nas partes da planta do primeiro corte foi influenciada pelas doses de $\mathrm{Cu}$, sendo tão mais alta quanto mais elevada a dose de $\mathrm{Cu}$. Nas plantas dessa alta dose também ocorreram baixas taxa de transpiração, eficiência do fotossistema II, taxa de transporte de elétrons e taxa de assimilação de $\mathrm{CO}_{2}$. No segundo período de crescimento, a rebrotação do capim foi fortemente afetada pelo $\mathrm{Cu}$ e ocorreu incremento da eficiência do fotossistema II e taxa de transporte de elétrons no capim tanzânia exposto à dose de $\mathrm{Cu}$ de $500 \mu \mathrm{mol} \mathrm{L}{ }^{-1}$. Nesse corte, o capim exposto ao $\mathrm{Cu}$ de $500 \mu \mathrm{mol} \mathrm{L}{ }^{-1}$ e crescido em $70 / 30$ de $\mathrm{NO}_{3}{ }^{-} / \mathrm{NH}_{4}{ }^{+}$apresentou maior atividade da SOD e menor concentração de MDA na parte aérea. A catalase, guaiacol peroxidase, ascorbato peroxidase e glutationa redutase foram ativadas principalmente nas raízes, sendo as atividades tão maiores quanto mais elevada a dose de $\mathrm{Cu}$. A combinação do $\mathrm{NO}_{3}{ }^{-}$ao $\mathrm{NH}_{4}{ }^{+}$promove alta fitoextração de $\mathrm{Cu}$ e o estresse oxidativo decorrente desse efeito afeta principalmente a fotossíntese das plantas, mas o suprimento com $\mathrm{NO}_{3}{ }^{-} \mathrm{e}_{4}{ }^{+}$ induz a ativação do sistema antioxidante da planta na tentativa de tolerar esse estresse.

Palavras-chave: Antioxidantes enzimáticos e não enzimáticos; Estresse oxidativo; Fitoextração de Cu; Fotossíntese de plantas forrageiras

\section{Abstract}

Nitrogen $(\mathrm{N})$ is largely related to the alleviation of $\mathrm{Cu}$ toxicity in plants and increases $\mathrm{Cu}$ phytoextraction. $\mathrm{Cu}$ toxicity causes oxidative stress, changing plant metabolism and photosynthesis, but there are no researchs associating nitrate and ammonium $\left(\mathrm{NO}_{3}{ }^{-} / \mathrm{NH}_{4}{ }^{+}\right)$proportions to alleviation of $\mathrm{Cu}$ toxicity. The objective was to evaluate the effect of $\mathrm{Cu}$ rates on the $\mathrm{Cu}$ accumulation in parts of Panicum maximum cv. Tanzania and the consequences of such accumulation in the indicators of oxidative stress, photosynthesis and antioxidants, elucidating the role of $\mathrm{NO}_{3}{ }^{-} / \mathrm{NH}_{4}{ }^{+}$proportions in the changes of these attributes. The experiment was carried out in a randomized complete block design, in a $3 \times 4$ factorial, with three replications. The factors were three proportions of $\mathrm{NO}_{3}-\mathrm{NH}_{4}{ }^{+}$ $\left(100 / 0,70 / 30\right.$ and 50/50) and four $\mathrm{Cu}$ rates $\left(0.3,250,500\right.$ and $\left.1000 \mu \mathrm{mol} \mathrm{L}^{-1}\right)$ in nutrient solution. Plants were grown during two periods of growth, and plants were exposed to $\mathrm{Cu}$ in the first period, 
but not is the second period. The highest $\mathrm{Cu}$ accumulation in shoots was obtained in plants supplied with $70 / 30$ of $\mathrm{NO}_{3}^{-} / \mathrm{NH}_{4}{ }^{+}$and $\mathrm{Cu}$ of $1000 \mu \mathrm{mol} \mathrm{L}{ }^{-1}$ at the first harvest. These plants also had high proline concentration in shoots, as well as high superoxide dismutase (SOD) activity in roots. In plants supplied with $\mathrm{N}$ only as $\mathrm{NO}_{3}{ }^{-}$and $\mathrm{Cu} 1000 \mu \mathrm{mol} \mathrm{L}^{-1}$ there was low $\mathrm{Cu}$ accumulation in shoots and also a high $\mathrm{Cu}$ accumulation in roots. In these plants, proline concentration in shoots and the SOD activity in roots were low, but the stomatal conductance at $\mathrm{Cu} 500 \mu \mathrm{mol} \mathrm{L}^{-1}$ was higher than in plants grown with $70 / 30$ of $\mathrm{NO}_{3}{ }^{-} / \mathrm{NH}_{4}{ }^{+}$. The malondialdehyde (MDA) concentration in plant parts at the first harvest was influenced by $\mathrm{Cu}$ rates, being increased as $\mathrm{Cu}$ rates increased. At this high $\mathrm{Cu}$ rate there was also low transpiration rate, low photosystem II efficiency, low electron transport rate and low $\mathrm{CO}_{2}$ assimilation rate. At the second growth period, grass regrowth was strongly affected by $\mathrm{Cu}$ toxicity and there was an increase in the photosystem II efficiency and electron transport rate in tanzania guineagrass exposed to $\mathrm{Cu}$ of $500 \mu \mathrm{mol} \mathrm{L}-1$. At the second harvest, grass exposed to $\mathrm{Cu}$ of $500 \mu \mathrm{mol} \mathrm{L}-1$ and grown in $70 / 30$ of $\mathrm{NO}_{3}{ }^{-} / \mathrm{NH}_{4}{ }^{+}$presented high SOD activity in shoots and low MDA concentration in these plant part. Catalase, guaiacol peroxidase, ascorbate peroxidase and glutathione reductase enzymes were activated mainly in the roots, being the activities high as $\mathrm{Cu}$ was applied at high $\mathrm{Cu}$ rate. The combination of $\mathrm{NO}_{3}{ }^{-}$and $\mathrm{NH}_{4}{ }^{+}$promotes high $\mathrm{Cu}$ phytoextraction and the oxidative stress resulting from this effect mainly affects the photosynthesis, but the supply with $\mathrm{NO}_{3}{ }^{-}$and $\mathrm{NH}_{4}{ }^{+}$induces the activation of the antioxidant system in an attempt to tolerate this stress.

Keywords: Cu phytoextraction; Enzymatic and non-enzymatic antioxidants; Oxidative stress; Photosynthesis of forage grasses

\subsection{Introdução}

O nitrogênio $(\mathrm{N})$ é o nutriente absorvido em maior quantidade pelas gramíneas forrageiras, sendo o principal modulador do metabolismo destas plantas. Esse efeito ocorre pelo fato do $\mathrm{N}$ participar da biossíntese de todos os aminoácidos, além de compor as bases nitrogenadas, membranas e hormônios vegetais (Heldt, 2004). A fertilização nitrogenada por meio do suprimento de $\mathrm{N}$ com formas iônicas de nitrato $\left(\mathrm{NO}_{3}{ }^{-}\right)$e amônio $\left(\mathrm{NH}_{4}{ }^{+}\right)$ promoveu efeitos favoráveis no crescimento de Panicum maximum cv. Aruana (Santos et al., 2013), assim como no crescimento e na fitoextração de metais em plantas de mostarda indiana (Brassica juncea) (Hamlin e Barker, 2006). O suprimento de $\mathrm{N}$ na forma de $\mathrm{NO}_{3}{ }^{-}$mostrou-se importante para favorecer a tolerância de plantas de alfafa (Medicago sativa) ao mercúrio ( $\mathrm{Hg}$ ) em solo contaminado, uma vez que plantas na fase de crescimento inicial fertilizadas com esse íon apresentaram menor conteúdo de malondialdeído (MDA), que é um indicador de peroxidação lipídica, em comparação às plantas não adubadas com $\mathrm{NO}_{3}{ }^{-}$(Carrasco-Gil et al., 2012). O suprimento de $\mathrm{NH}_{4}{ }^{+}$também pode incrementar o sistema de defesa antioxidante dos vegetais (Wang et al., 2010), o qual conduz à maior persistência das plantas em meio de cultivo contaminado com cádmio (Cd) e níquel (Ni) (Kováčik e Hedbavny, 2014). Contudo, diferente do que ocorre com o $\mathrm{NO}_{3}{ }^{-}$, o suprimento de $\mathrm{N}$ exclusivamente na forma de $\mathrm{NH}_{4}{ }^{+}$é restrito, devido à toxidez de altas doses dessa forma iônica de $\mathrm{N}$. O excesso de $\mathrm{NH}_{4}{ }^{+}$no meio de cultivo conduz a desordens nas plantas, que vão desde a acidificação excessiva do meio extra-celular (o qual dissipa o gradiente de prótons transmembrana, causando desbalanço osmótico), até outras desordens mais complexas, como a alteração da respiração celular (Esteban et al., 2016). Por isso, as pesquisas que procuram demonstrar o efeito positivo do $\mathrm{NH}_{4}^{+}$ no alívio da toxidez por metal trabalham com períodos curtos de exposição das plantas ao $\mathrm{NH}_{4}{ }^{+}$em solução nutritiva, tal qual ocorre com os elementos contaminantes (Kováčik e Hedbavny, 2014).

Uma alternativa ao problema da fitotoxidez do $\mathrm{NH}_{4}{ }^{+}$é fornecer as duas formas iônicas de $\mathrm{N}$ concomitantemente, combinando maiores proporções de $\mathrm{NO}_{3}^{-}$em relação ao $\mathrm{NH}_{4}{ }^{+}$e sendo tais proporções variadas com base na condição a ser imposta à planta. A energia economizada no processo de assimilação de parte 
do $\mathrm{N}$ fornecido na forma de $\mathrm{NH}_{4}{ }^{+}$, em relação ao suprimento com $\mathrm{N}$ exclusivo na forma de $\mathrm{NO}_{3}^{-}$, pode favorecer as plantas com potencial fitorremediador, criando as condições metabólicas necessárias para que a planta absorva, acumule e tolere grandes quantidades de Cu (Carrasco-Gil et al., 2012; Kováčik and Hedbavny, 2014). Apesar disso, há escassez de pesquisas que explorem o potencial do suprimento com $\mathrm{N}$ nesse sentido, tampouco as pesquisas atuais buscam associar as formas iônicas de $\mathrm{N}$ como indutoras de fitoextração de metais e de mecanismos de defesa antioxidante. Os estudos existentes se restringem a avaliar a produção de massa seca e o acúmulo de nutrientes, em experimentos com solução nutritiva contendo doses de zinco $(\mathrm{Zn})$ em concentração não tão elevadas, uma vez que o foco dessas pesquisas encontradas não está na fitoextração e no alívio de estresse oxidativo (Hamlin e Barker, 2006). Portanto, há carência de pesquisas que busquem compreender o papel de proporções de $\mathrm{NO}_{3}{ }^{-} / \mathrm{NH}_{4}{ }^{+}$na modulação do potencial fitorremediador de $\mathrm{Cu}$, tampouco os que procuram explicar os fenômenos encontrados a partir da avaliação de atributos bioquímicos e fisiológicos, sobretudo no capim tanzânia (Panicum maximum Jacq.), o qual tem se mostrado tolerante a excesso de metais pesados ( Monteiro et al., 2011b; Gilabel et al., 2014; Rabêlo et al., 2016).

$\mathrm{O} \mathrm{Cu}$ é um dos principais metais contaminantes e diversos trabalhos têm revelado novas áreas contaminadas com esse metal, como consequência da exploração de minérios (Cassella et al., 2007; Wu et al., 2011), do uso intensivo de fungicidas cúpricos em áreas agrícolas (Fernández-Calviño et al., 2010; Nogueirol et al., 2010; Wightwick et al., 2013) e do descarte inadequado de resíduos (Nogueirol et al., 2010; Nogueirol et al., 2013). Nas plantas, o Cu tem função relacionada ao transporte de elétrons da fotossíntese, pois é constituinte da plastocianina, o primeiro doador de elétrons do fotossistema II para o fotossistema I ( Pätsikkä et al., 2002; Epstein e Bloom, 2006;). Além disso, o $\mathrm{Cu}$ também tem papel significativo como co-fator enzimático, na respiração celular e no próprio metabolismo do N, uma vez que a toxidez por esse metal conduz à síntese excessiva de aminoácidos relacionados ao estresse oxidativo (Epstein e Bloom, 2006; Cohu e Pilon, 2007; Singh et al., 2010). Por ser micronutriente de plantas, é requerido em quantidades baixíssimas pela maioria das espécies cultivadas, o que significa que elevadas concentrações de $\mathrm{Cu}$ no meio de cultivo podem causar toxidez severa nas plantas (Fidalgo et al., 2013; Gilabel et al., 2014) e, em alguns casos, até conduzir as plantas à morte. Esses efeitos negativos atingem em menor escala as plantas tolerantes ao $\mathrm{Cu}$, uma vez que elas possuem mecanismos de defesa capazes de auxiliar na desintoxicação das espécies reativas de oxigênio (ERO), cuja produção é induzida pelas altas concentrações do metal no citoplasma (Liu et al., 2015).

Diversas espécies de plantas tem produção excessiva de ERO induzida pelo estresse por $\mathrm{Cu}$, a exemplo de Zea mays (Madejón et al., 2009), Medicago sativa (Wang et al., 2011), Oryza sativa (Thounaojam et al., 2012), Solanum nigrum (Fidalgo et al., 2013) e P. maximum (Gilabel et al., 2014), dentre outras espécies com relevância econômica na agropecuária. Gramíneas como o arroz (Oryza sativa) e o capim tanzânia tem o crescimento comprometido quando cultivadas em meio com excesso de $\mathrm{Cu}$, uma vez que a toxidez por esse metal induz a síntese de ERO na parte aérea que causa danos severos ao aparato fotossintético, assim como injúria nas raízes (Thounaojam et al., 2012; Gilabel et al., 2014). Mais especificamente, o estresse por toxidez de $\mathrm{Cu}$ induz a síntese excessiva do ânion superóxido $\left(\mathrm{O}_{2}^{-}\right)$nas células das plantas, assim como do peróxido de hidrogênio $\left(\mathrm{H}_{2} \mathrm{O}_{2}\right)$, que desencadeiam a peroxidação lipídica, a qual destrói as membranas celulares e provocam danos aos cloroplastos, ocasionando diminuição drástica da atividade fotossintética (Pätsikkä et al., 2002; Keunen et al., 2011; Xia et al., 2012).

De acordo com Myouga et al. (2008) e Mahanty et al. (2012), em condições ambientais de homeostase, plantas produzem ERO em quantidades controladas, pois esses compostos são essenciais à regeneração e morte celular. Entretanto, em condições de estresse abiótico, há indução da produção excessiva desses radicais, os quais induzem também as respostas de defesa das plantas a esse estresse, uma vez que puderam desenvolver (ao longo da 
co-evolução com o excesso de metais) eficientes mecanismos de defesa antioxidantes de caráter enzimático e não enzimático, relacionados principalmente à ação de dismutases, peroxidases e aminoácidos osmorreguladores. Este sistema de defesa da planta depende principalmente das enzimas superóxido dismutase (SOD), catalase (CAT), ascorbato peroxidase (APX), glutationa redutase (GR) e guaiacol peroxidase (GPX) (Gratão et al., 2008; Myouga et al., 2008), assim como do antioxidante não enzimático prolina, aminoácido que tem importante função osmorreguladora em condição de alteração da homeostase celular causada pelo estresse abiótico (Hayat et al., 2012; Singh et al., 2010). Nesse sentido, a adequada nutrição nitrogenada com base nas proporções de $\mathrm{NO}_{3}{ }^{-} / \mathrm{NH}_{4}{ }^{+}$, $\mathrm{em}^{-}$ condição de estresse por $\mathrm{Cu}$, pode incrementar a performance desses sistemas de defesa antioxidante e possibilitar a tolerância de plantas em situação de elevada toxidez por metal.

Objetivou-se avaliar o efeito de doses de Cu no acúmulo desse metal nas partes do capim tanzânia e a consequência desse acúmulo nos indicadores de estresse oxidativo, fotossintéticos e antioxidantes, elucidando o papel de proporções de $\mathrm{NO}_{3}{ }^{-} / \mathrm{NH}_{4}{ }^{+}$nas modificações desses atributos e no incremento da tolerância do capim tanzânia ao excesso de Cu.

\subsection{Material e Métodos}

\subsubsection{Condições experimentais}

O capim tanzânia foi cultivado em casa de vegetação com sistema de ventilação/exaustão que permite troca gasosa automática e manutenção da temperatura abaixo de $33^{\circ} \mathrm{C}$. As mudas de capim foram provenientes de sementes germinadas em bandejas contendo areia lavada com água desionizada. No total, 15 plântulas com 4 a $5 \mathrm{~cm}$ de altura foram transplantadas para cada unidade experimental contendo quartzo moído (sílica) como substrato. O delineamento experimental utilizado foi de blocos completos ao acaso, constituindo-se o experimento de um fatorial $3 \times 4$ com seis repetições, sendo três blocos destinados às avaliações metabólicas e três às avaliações fotossintéticas e nutricionais. Os fatores empregados no experimento foram três proporções de $\mathrm{NO}_{3}{ }^{-} / \mathrm{NH}_{4}{ }^{+}(100 / 0,70 / 30$ e $50 / 50)$ combinadas com quatro doses de $\mathrm{Cu}(0,3 ; 250 ; 500$ e $1000 \mu \mathrm{mol} \mathrm{L}-1)$.

Foi utilizada a solução nutritiva de Hoagland e Arnon (1950) contendo as proporções de $\mathrm{NO}_{3}^{-} / \mathrm{NH}_{4}{ }^{+}$ com N de $15 \mathrm{mmol} \mathrm{L}^{-1}$ e diluída a $20 \%$ da força iônica por sete dias após o transplantio das mudas. O desbaste das plantas foi realizado ao longo de cinco dias até restarem cinco plantas em cada vaso. Após os sete dias iniciais de crescimento das mudas nas unidades experimentais, foi aplicada a solução nutritiva com 100\% da força iônica, mantendo as proporções de $\mathrm{NO}_{3}^{-} / \mathrm{NH}_{4}{ }^{+}$na dose de $\mathrm{N}$ de $15 \mathrm{mmol} \mathrm{L}^{-1}$ e de $\mathrm{Cu}$ de $0,3 \mu \mathrm{mol} \mathrm{L}^{-1}$ (ambas recomendadas na solução de Hoagland e Arnon, 1950). Com 21 dias de crescimento na solução contendo 100\% da força iônica, as plantas também foram expostas às doses de Cu de 250, 500 e $1000 \mu \mathrm{mol} \mathrm{L} \mathrm{L}^{-1}$. A solução nutritiva foi circulada seis vezes ao dia no início do período de crescimento e três vezes nas demais etapas, completando-se diariamente o volume evapotranspirado com água desionizada. A renovação da solução foi realizada semanalmente para evitar que o $\mathrm{NH}_{4}{ }^{+}$fosse oxidado a $\mathrm{NO}_{3}{ }^{-}$, mantendo assim as proporções de $\mathrm{NO}_{3}{ }^{-} / \mathrm{NH}_{4}{ }^{+}$estabelecidas.

Avaliaram-se dois períodos de crescimento das plantas, o primeiro com corte executado a $5 \mathrm{~cm}$ do substrato e o segundo com corte rente ao substrato. O primeiro corte das plantas foi efetuado com 35 dias de crescimento e sete dias de exposição às doses tóxicas de $\mathrm{Cu}$, baseado na ocorrência de toxidez severa causada pela dose de $\mathrm{Cu}$ de $1000 \mu \mathrm{mol} \mathrm{L}{ }^{-1}$. Após o primeiro corte das plantas a solução nutritiva foi renovada, mantendo-se as 
proporções de $\mathrm{NO}_{3}{ }^{-} / \mathrm{NH}_{4}{ }^{+}$estabelecidas e a dose de $\mathrm{Cu}$ de $0,3 \mu \mathrm{mol} \mathrm{L} \mathrm{L}^{-1}$. O segundo corte ocorreu com o crescimento das plantas por 21 dias de rebrotação, sem reaplicação das doses tóxicas de Cu. Assim, o efeito do $\mathrm{Cu}$ no segundo corte do capim foi devido ao residual aplicado ao final do primeiro crescimento das plantas.

Por ocasião dos cortes, a parte aérea foi separada em lâminas de folhas recém-expandidas ou diagnósticas (LR) e demais componentes da parte aérea (DC), sendo que no segundo corte também foi coletadas as raízes. O material vegetal frescos dos vasos destinados à avaliação metabólica foi imediatamente acondicionado em papel alumínio e congelado em $\mathrm{N}$ líquido, com o intuito de cessar as reações metabólicas, para posterior armazenagem em "freezer" com temperatura de $-80^{\circ}$ C. Posteriormente, estas amostras foram trituradas em moinho adequado à moagem com $\mathrm{N}$ líquido. Nos blocos destinados à avaliação do acúmulo de $\mathrm{Cu}$, as partes das plantas foram secas em estufa de circulação forçada a $65^{\circ} \mathrm{C}$ por 72 horas e o material vegetal foi triturado em moinhos tipo Wiley.

\subsubsection{Determinação de Cu no tecido vegetal}

A concentração de $\mathrm{Cu}$ nas partes da planta foi determinada segundo metodologia de Sarruge e Haag (1974), após digestão nítrico-perclórica do material vegetal e diluição em água desionizada, com leitura no extrato por espectrofotometria de absorção atômica. O acúmulo de $\mathrm{Cu}$ nas partes da planta foi obtido pela multiplicação da concentração de $\mathrm{Cu}$ pela respectiva massa seca produzida.

\subsubsection{Indicadores de estresse oxidativo}

A peroxidação lipídica foi avaliada a partir da concentração de malondialdeído (MDA) nas partes da planta, uma vez que é o produto final da peroxidação de lipídios. Empregou-se o teste do ácido 2-tiobarbitúrico (TBA), segundo metodologia de Heath e Packer (1968). O tecido vegetal congelado foi homogeneizado em almofariz com auxílio de pistilo, em solução de ácido tricloroacético (TCA, $1 \mathrm{~g} \mathrm{~L}^{-1}$ ), sendo centrifugado a $10.000 \mathrm{rpm}$ por 10 minutos, a $4^{\circ}$ C. Alíquotas do sobrenadante foram retiradas e transferidas para tubos de plástico de $1,5 \mathrm{~mL}$ resistentes ao calor, com adição de solução de TCA (200 $\left.\mathrm{g} \mathrm{L}^{-1}\right)+$ TBA $\left(5 \mathrm{~g} \mathrm{~L}^{-1}\right)$, para serem incubadas em banho seco por 30 minutos, a $95^{\circ} \mathrm{C}$. Para cessar a reação, os tubos foram colocados em gelo por 10 minutos e depois em temperatura ambiente por 15 minutos, realizando as leituras em espectrofotômetro a 535 e 600 ทm. A concentração de MDA foi determinada a partir da diferença das absorbâncias, associada à utilização do coeficiente de extinção de $155 \mathrm{mmol}^{-1} \mathrm{~cm}^{-1}$.

A concentração de peróxido de hidrogênio $\left(\mathrm{H}_{2} \mathrm{O}_{2}\right)$ nas partes das plantas foi determinada no mesmo extrato vegetal homogeneizado com TCA $\left(1 \mathrm{~g} \mathrm{~L}^{-1}\right)$, segundo metodologia de Velikova et al. (2000). Outra alíquota do sobrenadante do extrato homogeneizado foi transferido para microtubos de 1,5 mL, sendo adicionado tampão fosfato de potássio $\left(100 \mathrm{mmol} \mathrm{L}^{-1}\right)$ e iodeto de potássio $(1 \mathrm{~mol} \mathrm{~L}-1)$ e incubado, em gelo por 60 minutos, no escuro. Ao término desse período, os tubos foram colocados em temperatura ambiente por 15 minutos, no escuro. A leitura no sobrenadante foi realizada em espectrofotômetro a $390 \eta \mathrm{m}$ e os valores de concentração obtidos a partir de curva padrão de $\mathrm{H}_{2} \mathrm{O}_{2}$. 


\subsubsection{Extração e quantificação de proteínas}

O método de extração de proteína solúvel foi o de Monteiro et al. (2011a). O tecido vegetal congelado e triturado foi homogeneizado em solução tampão fosfato de potássio $\left(100 \mathrm{mmol} \mathrm{L}^{-1}, \mathrm{pH} 7,5\right)$ contendo ácido etilenodiamino tetra-acético (EDTA, $1 \mathrm{mmol} \mathrm{L}^{-1}$ ) e ditiotreitol (DTT, $3 \mathrm{mmol} \mathrm{L}^{-1}$ ), sendo adicionado no momento da homogeneização polivinilpolipirrolidona (PVPP). O extrato foi centrifugado a $10.000 \mathrm{rpm}$ por 30 minutos, a temperatura de $4^{\circ} \mathrm{C}$, sendo o sobrenadante armazenado em "freezer" com temperatura de $-80^{\circ} \mathrm{C}$. A determinação da concentração de proteína solúvel foi executada de acordo com Bradford (1976), quantificando os valores a partir de curva padrão de albumina de soro bovino (BSA).

\subsubsection{Atividade de enzimas do sistema antioxidante}

\subsubsection{Superóxido dismutase (EC 1.15.1.1)}

A metodologia foi executada como descrita por Azevedo et al. (1998), sendo a atividade da SOD detectada por meio de eletroforese em géis de poliacrilamida não-desnaturante (PAGE). Extratos proteicos contendo $20 \mu \mathrm{g}$ de proteína foram misturados à solução contendo azul de bromofenol $\left(5 \mathrm{~g} \mathrm{~L}^{-1}\right)$, glicerol e trizma $\left(60 \mathrm{~g} \mathrm{~L}^{-1}\right)$. Essa mistura foi adicionado aos sulcos do gel de empacotamento, este último contendo acrilamida $\left(400 \mathrm{~g} \mathrm{~L}^{-1}\right)$, trizma (60 $\left.\mathrm{g} \mathrm{L}^{-1}\right), \mathrm{N}, \mathrm{N}, \mathrm{N}^{\prime}, \mathrm{N}^{\prime}$ tetrametiletilenodiamina (TEMED) e persulfato de amônio $\left(10 \mathrm{~g} \mathrm{~L}^{-1}\right)$. A composição do gel de corrida, onde há a deposição das bandas das proteínas, foi similar ao gel de empacotamento, sendo a concentração do trizma maior (363 $\mathrm{g} \mathrm{L}^{-1}$ ), com corrente da eletroforese ajustada para $15 \mathrm{~mA} /$ gel. Ao final da corrida, o gel foi lavado com água desionizada e incubado por 30 minutos, em caixa escura contendo solução tampão de fosfato de potássio (100 mmol L-1, $\mathrm{pH} 7,8)$ contendo EDTA $\left(1 \mathrm{mmol} \mathrm{L}^{-1}\right)$, cloreto de tetrazólio nitroazul $\left(\mathrm{NBT}, 0,1 \mathrm{mmol} \mathrm{L}^{-1}\right)$, riboflavina $\left(0,05 \mathrm{~g} \mathrm{~L}^{-1}\right)$ e TEMED. Depois, os géis foram lavados com água desionizada e iluminados com lâmpada fluorescente em água até que as bandas acromáticas da SOD pudessem ficar visíveis, em fundo de cor roxa. Ao final, a reação nos géis foi cessada com a aplicação de ácido acético. As bandas foram comparadas qualitativamente com o padrão de SOD bovino.

\subsubsection{Catalase (EC 1.11.1.6)}

A atividade da catalase foi determinada de acordo com Monteiro et al. (2011a). No momento da determinação, foi preparada uma solução estoque de tampão de fosfato de potássio $\left(100 \mathrm{mmol} \mathrm{L}^{-1}\right.$, pH 7,5) contendo $\mathrm{H}_{2} \mathrm{O}_{2}$ concentrado. Uma alíquota dessa solução foi misturada ao extrato proteico, em cubetas, o que deu início à reação. A atividade foi medida a partir da decomposição do $\mathrm{H}_{2} \mathrm{O}_{2}$, por 1 minuto, realizando a leitura a $25^{\circ} \mathrm{C}$ em espectrofotômetro a $240 \eta \mathrm{m}$. 


\subsubsection{Glutationa redutase (EC 1.6.4.2)}

A atividade dessa enzima foi determinada segundo Gratão et al. (2008). Alíquotas de solução tampão de fosfato de potássio (100 $\mathrm{mmol} \mathrm{L}^{-1}$, pH 7,5) e ácido 2-nitrobenzóico (DTNB $3 \mathrm{mmol} \mathrm{L}^{-1}$ ) foram colocadas em banho de água a $30^{\circ} \mathrm{C}$. Atingida a temperatura na solução, foi adicionada nicotinamida adenina dinucleotídeo reduzida (NADPH, $2 \mathrm{mmol} \mathrm{L}^{-1}$ ), glutationa oxidada (GSSG, $20 \mathrm{mmol} \mathrm{L}^{-1}$ ) e extrato vegetal, dando início à reação. A atividade da enzima foi medida estimando a redução da glutationa oxidada em 1 minuto, sendo a leitura realizada em espectrofotômetro a $412 \eta \mathrm{m}$.

\subsubsection{Ascorbato peroxidase (EC 1.11.1.11)}

A determinação dessa enzima foi realizada a partir da metodologia descrita por Cakmak e Horst (1991). O extrato vegetal foi adicionado em solução tampão de fosfato de potássio $\left(80 \mathrm{mmol} \mathrm{L}^{-1}\right.$, $\left.\mathrm{pH} 7\right)$ contendo ácido ascórbico $\left(5 \mathrm{mmol} \mathrm{L}^{-1}\right)$ e EDTA $\left(1,45 \mathrm{mmol} \mathrm{L}^{-1}\right)$ a $30^{\circ} \mathrm{C}$ (banho maria). No momento da leitura, foi adicionado $\mathrm{H}_{2} \mathrm{O}_{2}$ concentrado. A atividade da enzima foi determinada estimando-se a oxidação do ascorbato por 1 minuto, em cubeta de quartzo, realizando a leitura no espectrofotômetro a $290 \eta \mathrm{m}$. A atividade da enzima foi calculada a partir do coeficiente de extinção de ascorbato de $2,8 \mathrm{mmol}^{-1} \mathrm{~cm}^{-1}$.

\subsubsection{Guaiacol peroxidase (EC 1.11.1.7)}

Foi baseada na metodologia de Matsuno e Uritani (1972), misturando extrato proteico ao tampão fosfato de sódio $\left(28,4 \mathrm{~g} \mathrm{~L}^{-1}, \mathrm{pH}\right.$ 5,0) contendo ácido cítrico $\left(21 \mathrm{~g} \mathrm{~L}^{-1}\right)$, guaiacol e $\mathrm{H}_{2} \mathrm{O}_{2}$ com aquecimento a $30^{\circ} \mathrm{C}$, por 15 minutos. Após a incubação, a reação foi cessada com a aplicação de metabissulfito de sódio $\left(20 \mathrm{~g} \mathrm{~L}^{-1}\right)$, com posterior colocação das amostras em banho de gelo, para descanso por 10 minutos, realizando a leitura em espectrofotômetro a $450 \eta \mathrm{m}$.

\subsubsection{Concentração de prolina}

A concentração do aminoácido prolina nas partes da planta foi determinada segundo Bates et al. (1973). As amostras foram homogeneizadas em ácido sulfosalićlico $\left(30 \mathrm{~g} \mathrm{~L}^{-1}\right)$, com posterior centrifugação a $10.000 \mathrm{rpm}$ por 20 minutos, a $15^{\circ} \mathrm{C}$. Uma alíquota do sobrenadante foi colocada em tubos de ensaio para reação com solução contendo ninidrina $\left(25 \mathrm{~g} \mathrm{~L}^{-1}\right)$, ácido acético glacial e ácido fosfórico $\left(6 \mathrm{~mol} \mathrm{~L}^{-1}\right)$. Os tubos foram aquecidos em água a $100^{\circ} \mathrm{C}$, por 1 hora e ao termino desse período os tubos foram colocadas em banho de gelo por 10 minutos. Depois, foi adicionado tolueno concentrado, sendo os tubos agitados vigorosamente por 20 segundos e esperando por mais 10 minutos para a separação total das fases. A leitura foi realizada na fase superior, em espectrofotômetro a $520 \eta \mathrm{m}$, quantificando os valores a partir de curva padrão de prolina. 


\subsubsection{Atividade fotossintética}

Para proporcionar ambiente uniforme e constante, as unidades experimentais destinadas a avaliação nutricional foram transportadas para câmara de crescimento para aclimatação por $24 \mathrm{~h}$, com temperatura constante de $27^{\circ} \mathrm{C}$, intensidade luminosa das luzes artificiais de $400 \mu \mathrm{mol} \mathrm{m}{ }^{-2} \mathrm{~s}^{-1} \mathrm{PAR}_{\text {e }} \mathrm{CO}_{2}$ atmosférico médio de $350 \mathrm{mg} \mathrm{L}^{-1}$. A atividade fotossintética foi avaliada no terço médio das LR, excluindo-se a nervura central, ao final de cada período de crescimento do capim, utilizando o analisador de fotossíntese IRGA WALZ-GFS-3000 de fluorescência de troca gasosa. Foram quantificadas a taxa de assimilação de $\mathrm{CO}_{2}(\mathrm{~A})$, taxa de transpiração (E), condutância estomática (CE), eficiência quântica do fotossistema II (EFSII) e taxa de transporte de elétrons (TTE).

\subsubsection{Análise estatística}

A análise estatística dos resultados foi realizada utilizando o software "Statistical Analysis System" (Sas Institute, 2008). Nos casos em que a interação $\mathrm{NO}_{3}{ }^{-} / \mathrm{NH}_{4}{ }^{+} \times \mathrm{Cu}$ foi significativa, efetuou-se a comparação de médias para as proporções de $\mathrm{NO}_{3}{ }^{-} / \mathrm{NH}_{4}{ }^{+}$dentro de cada dose de $\mathrm{Cu}$ e para as doses de $\mathrm{Cu}$ dentro de cada proporção de $\mathrm{NO}_{3}-\mathrm{NH}_{4}{ }^{+}$. Nos casos da interação não ter sido significativa e o teste $\mathrm{F}$ mostrar significância para os fatores isolados, foi procedida análise de regressão para as doses de $\mathrm{Cu}$ e/ou comparações de médias para as proporções de $\mathrm{NO}_{3}{ }^{-} / \mathrm{NH}_{4}{ }^{+}$. Para comparação de médias foi escolhido o teste de Tukey a 5\%. No caso da dose mais tóxica de $\mathrm{Cu}$ de $1000 \mu \mathrm{mol} \mathrm{L} \mathrm{L}^{-1}$ conduzir à não rebrotação e morte das plantas, perdendo-se todas as repetições de uma combinação dos níveis dos fatores, a análise de variância foi executada com o emprego de fatorial $3 \times 3$. Os resultados que não apresentaram distribuição normal foram transformados com o emprego da fórmula $\sqrt{x}$ ou $\log (x)$ para se adequar aos pré-requisitos da análise de variância.

\subsection{Resultados}

\subsubsection{Primeiro corte}

\subsubsection{Acúmulo de cobre na parte aérea}

A interação proporções de $\mathrm{NO}_{3}{ }^{-} / \mathrm{NH}_{4}{ }^{+} \times$doses de $\mathrm{Cu}$ foi significativa para o acúmulo de $\mathrm{Cu}$ na parte aérea do capim, sendo que nas doses de $\mathrm{Cu}$ de 250, 500 e $1000 \mu \mathrm{mol} \mathrm{L}{ }^{-1}$ os maiores acúmulos foram constatados na proporção 70/30 de $\mathrm{NO}_{3}^{-} / \mathrm{NH}_{4}{ }^{+}$e o menor na proporção 100/0 de $\mathrm{NO}_{3}^{-} / \mathrm{NH}_{4}{ }^{+}$(Figura 24). Destaca-se a proporção $70 / 30$ de $\mathrm{NO}_{3}{ }^{-} / \mathrm{NH}_{4}{ }^{+}$na mais elevada dose de $\mathrm{Cu}$ de $1000 \mu \mathrm{mol} \mathrm{L}^{-1}$, a qual apresentou médias de acúmulo de 8,1 mg de Cu por vaso. 


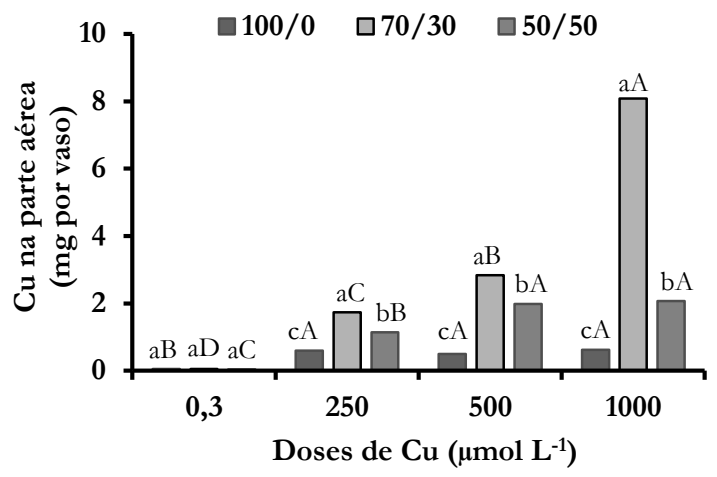

Figura 24. Acúmulo de $\mathrm{Cu}$ na parte aérea do capim tanzânia no primeiro corte em função de doses de Cu e proporções de $\mathrm{NO}_{3}-/ \mathrm{NH}_{4}{ }^{+}$em solução nutritiva. Letras minúsculas distintas mostram diferença significativa pelo teste de Tukey entre proporções de $\mathrm{NO}_{3}-/ \mathrm{NH}_{4}{ }^{+}$dentro de cada dose de $\mathrm{Cu}$ e letras maiúsculas distintas entre as doses de $\mathrm{Cu}$ dentro de cada proporção de $\mathrm{NO}_{3}{ }^{-} / \mathrm{NH}_{4}{ }^{+}$. Os resultados originais foram transformados em $\sqrt{x}$ para se ajustar à distribuição normal. Coeficiente de variação $(\%)=6,9$.

\subsubsection{Indicadores de estresse oxidativo nas partes da planta}

Os resultados mostraram que a interação proporções de $\mathrm{NO}_{3}{ }^{-} / \mathrm{NH}_{4}{ }^{+} \times$doses de $\mathrm{Cu}$ não foi significativa para concentração de MDA nas LR e DC da parte aérea do capim tanzânia. Esta concentração nas LR foi alterada isoladamente pelas doses de $\mathrm{Cu}$ (Figura 25a) e proporções de $\mathrm{NO}_{3}{ }^{-} / \mathrm{NH}_{4}{ }^{+}$(Figura 25b). A concentração de MDA nas LR apresentou ajuste linear com as doses de $\mathrm{Cu}$. As maiores médias de concentração de MDA nas LR foram verificadas nas proporções $70 / 30$ e $50 / 50$ de $\mathrm{NO}_{3}{ }^{-} / \mathrm{NH}_{4}{ }^{+}$, as quais não diferem entre si e foram maiores que as constatadas nas plantas supridas com $\mathrm{N}$ somente na forma de $\mathrm{NO}_{3}{ }^{-}$(Figura 25b). Para a concentração de MDA nos DC da parte aérea, houve ajuste dos resultados ao modelo exponencial e somente nas duas mais baixas doses de Cu a concentração de MDA foi menor (Figura 25c). 

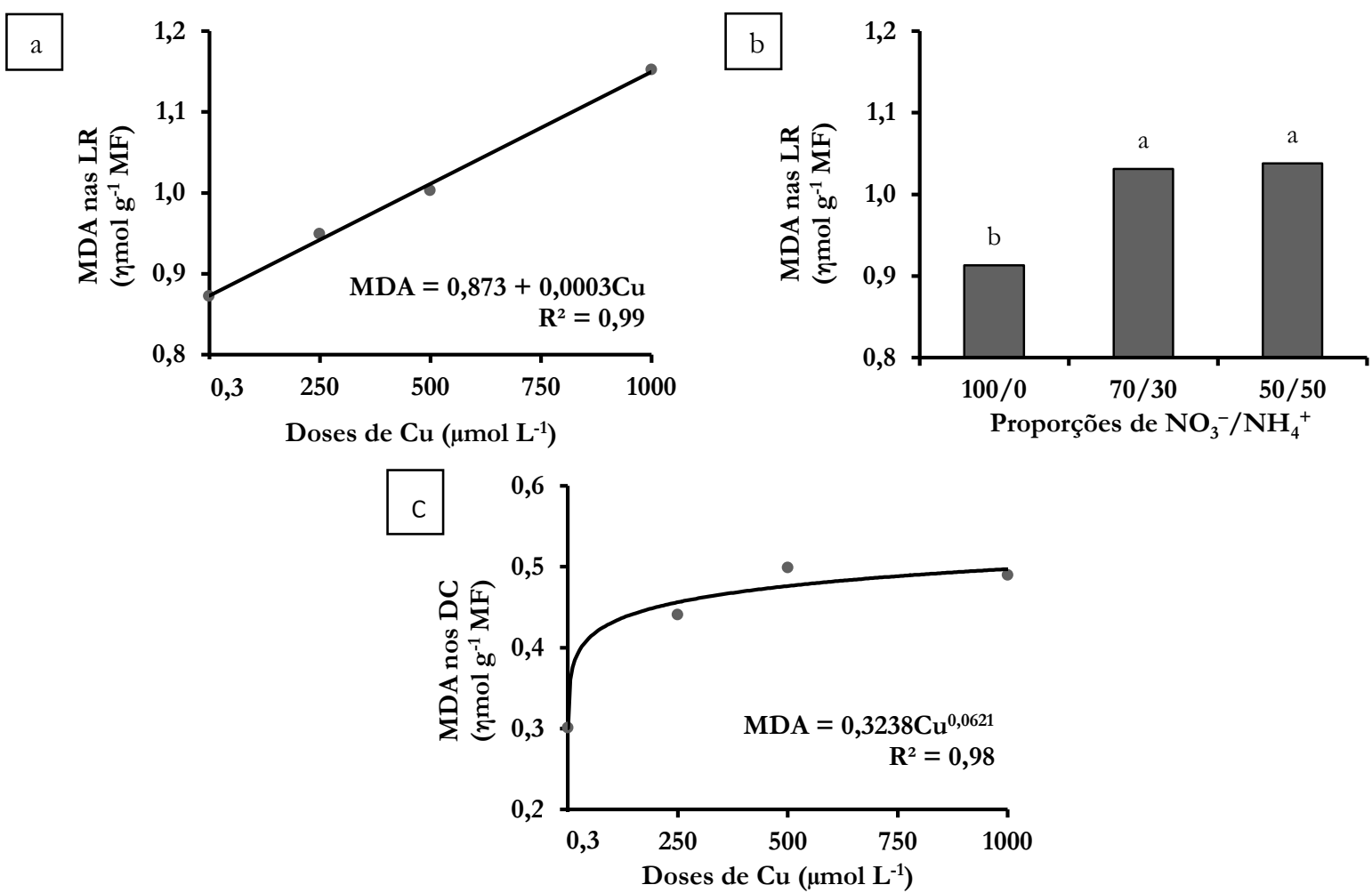

Figura 25. Concentração de malondialdeído (MDA) em função de doses de $\mathrm{Cu}$ (a) ou proporções de $\mathrm{NO}_{3}{ }^{-} / \mathrm{NH}_{4}{ }^{+}$(b) nas lâminas diagnósticas (LR) e concentração de MDA nos demais componentes (DC) da parte aérea em função de doses de Cu (c) no capim tanzânia no primeiro corte, cultivado em solução nutritiva. Na figura 25b, letras minúsculas distintas mostram diferença significativa pelo teste de Tukey. Os resultados originais foram transformados em $\sqrt{x}$ para se ajustar a distribuição normal. Coeficiente de variação $(\%)=16,9(\mathrm{a}, \mathrm{b})$ e 11,7 (c).

A interação proporções de $\mathrm{NO}_{3}{ }^{-} / \mathrm{NH}_{4}{ }^{+} \times$doses de $\mathrm{Cu}$ não foi significativa para a concentração de $\mathrm{H}_{2} \mathrm{O}_{2}$ nas LR e DC da parte aérea do capim tanzânia no primeiro corte, mas esta concentração nessas partes do capim foi influenciada isoladamente pelas proporções de $\mathrm{NO}_{3}{ }^{-} / \mathrm{NH}_{4}{ }^{+}$. Os resultados mostraram que a concentração de $\mathrm{H}_{2} \mathrm{O}_{2}$ nas LR (Figura 26a) e DC da parte aérea (Figura 26b) foram maiores e não diferiram entre si nas plantas que receberam as proporções de $70 / 30$ e $50 / 50$ de $\mathrm{NO}_{3}-/ \mathrm{NH}_{4}{ }^{+}$em relação às plantas supridas com $\mathrm{N}$ exclusivamente na forma de $\mathrm{NO}_{3}{ }^{-}$.
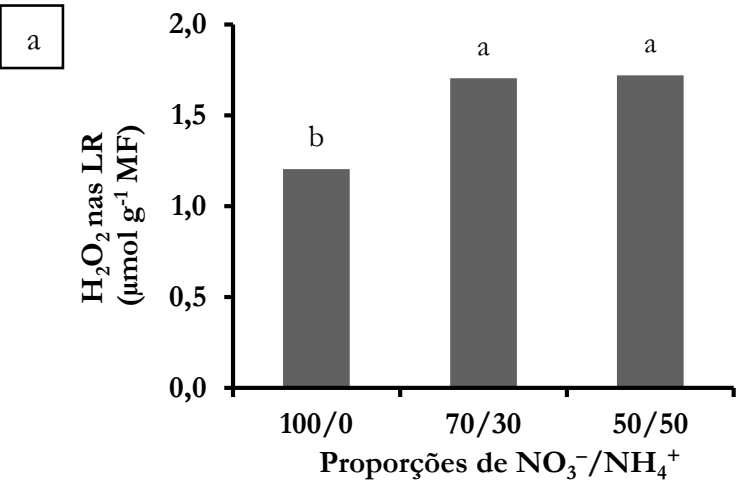

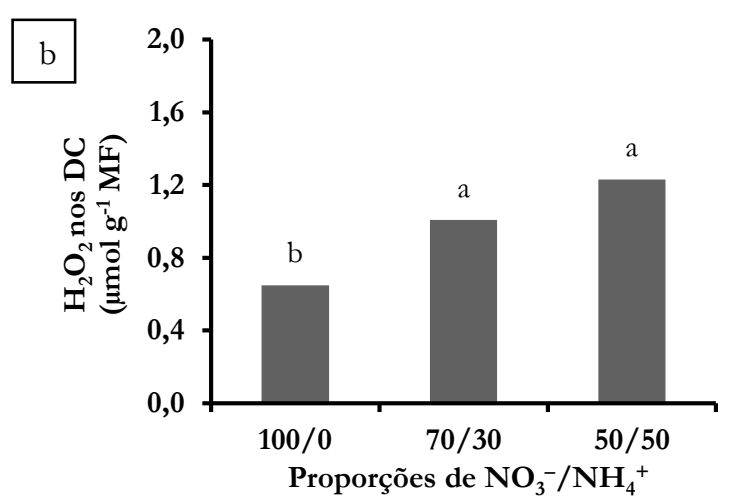

Figura 26. Concentração de peróxido de hidrogênio $\left(\mathrm{H}_{2} \mathrm{O}_{2}\right)$ nas lâminas diagnósticas (LR) (a) e demais componentes (DC) da parte aérea (b) do capim tanzânia no primeiro corte em função de proporções de $\mathrm{NO}_{3}-/ \mathrm{NH}_{4}{ }^{+}$em solução nutritiva. Letras minúsculas distintas mostram diferença significativa pelo teste de Tukey. Os resultados originais foram transformados em $\sqrt{x}$ para se ajustar a distribuição normal. Coeficiente de variação (\%) = 13,2 (a) e 8,9 (b). 


\subsubsection{Atividade fotossintética nas lâminas diagnósticas}

Os resultados mostraram que a interação proporções de $\mathrm{NO}_{3}{ }^{-} / \mathrm{NH}_{4}{ }^{+} \times$doses de $\mathrm{Cu}$ foi significativa apenas para a condutância estomática (Figura 27a), enquanto a taxa de transpiração (Figura 27b), taxa de assimilação de $\mathrm{CO}_{2}$ (Figura 27c), eficiência quântica do fotossistema II (figura 27d) e taxa de transporte de elétrons (Figura 27e) foram significativamente influenciadas pelas doses de $\mathrm{Cu}$.
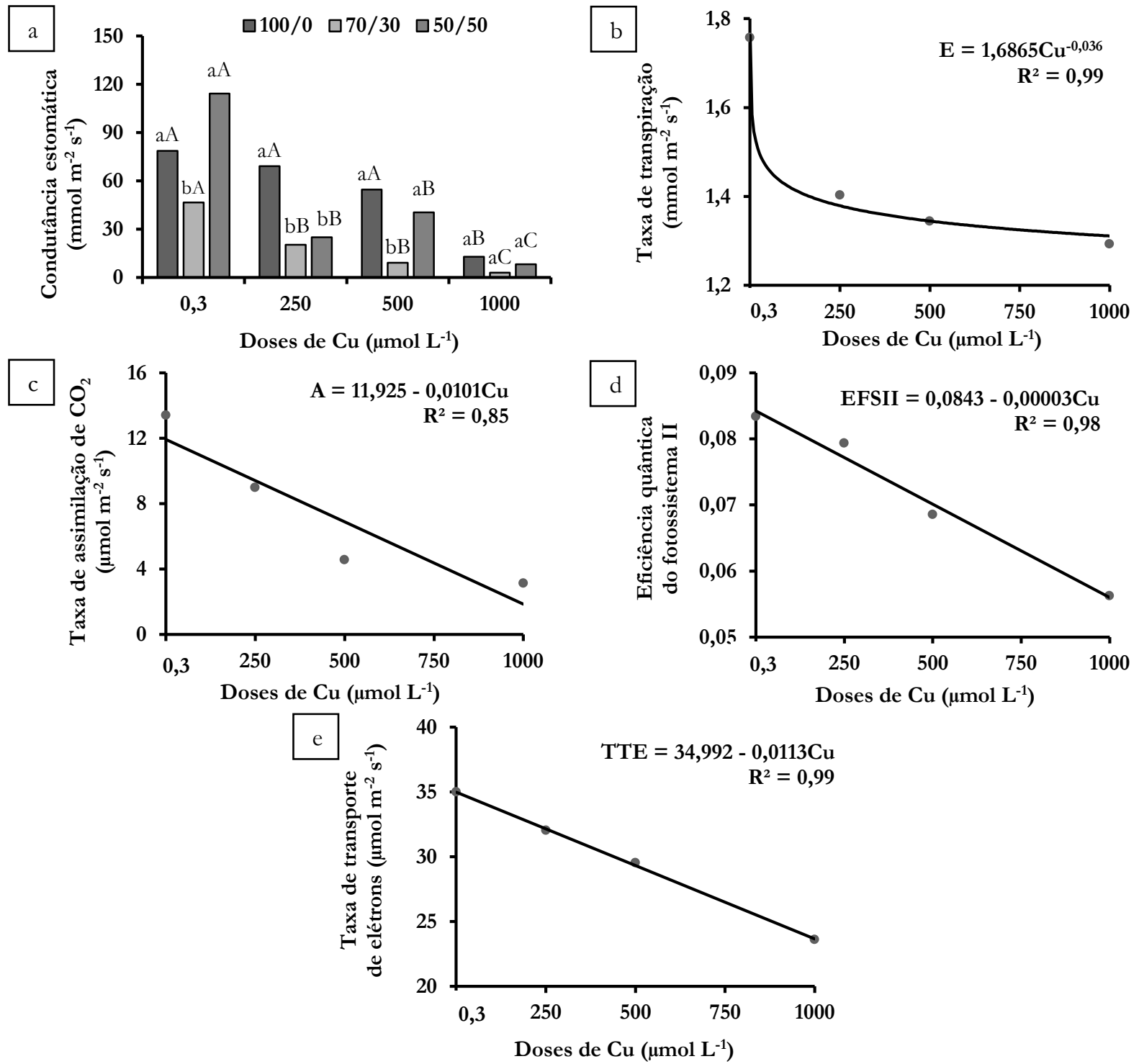

Figura 27. Condutância estomática em função de doses de $\mathrm{Cu}$ e proporções de $\mathrm{NO}_{3}^{-} / \mathrm{NH}_{4}{ }^{+}$(a), taxa de assimilação de $\mathrm{CO}_{2}$ (b), taxa de transpiração (c), eficiência quântica do fotossistema II (d), taxa de transporte de elétrons (e) nas lâminas diagnósticas do capim tanzânia no primeiro corte em função de doses de $\mathrm{Cu}$ em solução nutritiva. $\mathrm{Na}$ figura 27a, letras minúsculas distintas mostram diferença significativa pelo teste de Tukey entre proporções de $\mathrm{NO}_{3}-\mathrm{NH}_{4}{ }^{+}$dentro de cada dose de $\mathrm{Cu}$ e letras maiúsculas distintas entre as doses de $\mathrm{Cu}$ dentro de cada proporção $\mathrm{NO}_{3}-/ \mathrm{NH}_{4}{ }^{+}$. Os resultados originais foram transformados em $\sqrt{x}$ para se ajustar à distribuição normal. Coeficiente de variação (\%) = 16,5 (a), 25,1 (b), 26,8 (c), 25,4 (d) e 30 (e).

Os valores de condutância estomática foram menores nas mais elevadas doses de Cu (Figura 27a), apesar que na dose de $\mathrm{Cu}$ de $500 \mu \mathrm{mol} \mathrm{L}{ }^{-1}$ as médias das proporções 100/0 e 50/50 de $\mathrm{NO}_{3}^{-} / \mathrm{NH}_{4}{ }^{+}$foram similares e maiores que a média da proporção $70 / 30 \mathrm{de} \mathrm{NO}_{3}{ }^{-} / \mathrm{NH}_{4}{ }^{+}$. Na dose de $\mathrm{Cu}$ de $250 \mu \mathrm{mol} \mathrm{L}{ }^{-1}$ apenas a proporção $100 / 0$ de $\mathrm{NO}_{3}-/ \mathrm{NH}_{4}{ }^{+}$apresentou média maior que as demais proporções de $\mathrm{NO}_{3}{ }^{-} / \mathrm{NH}_{4}{ }^{+}$. A taxa de transpiração se 
ajustou ao modelo exponencial, mostrando que somente na mais baixa dose de $\mathrm{Cu}$ a taxa de transpiração é expressivamente maior (Figura 27b). Para a taxa de assimilação de $\mathrm{CO}_{2}$, verificou-se ajuste linear com as doses de $\mathrm{Cu}$ (Figura 27c), com diferença de valores de mais de 75\% da dose de $\mathrm{Cu}$ de 0,3 para a dose de $1000 \mu \mathrm{mol} \mathrm{L}^{-1}$. Os resultados para eficiência quântica do fotossistema II (Figura 27d) e a taxa de transporte de elétrons (Figura 27e) se ajustaram ao modelo linear, sendo os valores menores quanto mais elevada a dose de Cu aplicada.

\subsubsection{Concentração de prolina nas partes da planta}

A interação proporções de $\mathrm{NO}_{3}{ }^{-} / \mathrm{NH}_{4}{ }^{+} \times$doses de $\mathrm{Cu}$ foi significativa para a concentração de prolina nas LR (Figura 28a) e DC da parte aérea do capim (Figura 28b) e os resultados indicaram que as maiores concentrações de prolina nessas partes da planta foram obtidas na dose de $\mathrm{Cu}$ de $1000 \mu \mathrm{mol} \mathrm{L}{ }^{-1}$, nas plantas que receberam 70/30 e $50 / 50$ de $\mathrm{NO}_{3}{ }^{-} / \mathrm{NH}_{4}{ }^{+}$. Nas plantas cultivadas com $\mathrm{N}$ somente na forma de $\mathrm{NO}_{3}{ }^{-}$a concentração de prolina não foi alterada pelas doses de $\mathrm{Cu}$ nessas partes da planta.
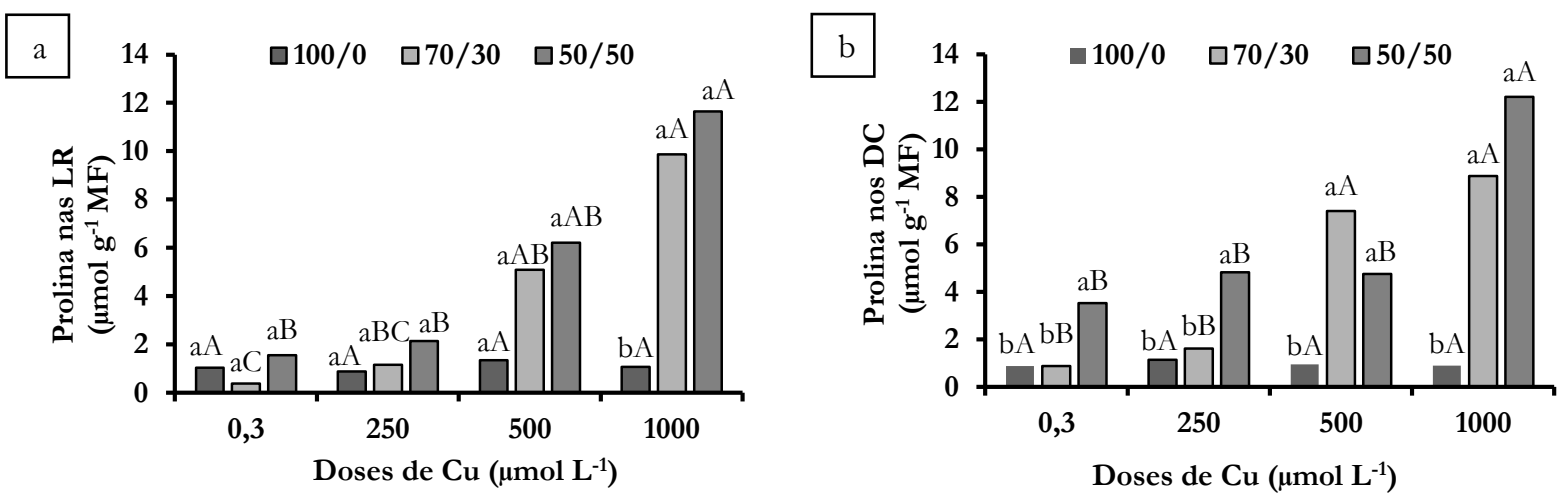

Figura 28. Concentração de prolina nas lâminas diagnósticas (LR) (a) e nos demais componentes (DC) da parte aérea (b) do capim tanzânia no primeiro corte em função de doses de $\mathrm{Cu}$ e proporções de $\mathrm{NO}_{3}{ }^{-} / \mathrm{NH}_{4}{ }^{+}$em solução nutritiva. Letras minúsculas distintas mostram diferença significativa pelo teste de Tukey entre proporções de $\mathrm{NO}_{3}{ }^{-} / \mathrm{NH}_{4}{ }^{+}$dentro de cada dose de $\mathrm{Cu}$ e letras maiúsculas distintas entre as doses de $\mathrm{Cu}$ dentro de cada proporção de $\mathrm{NO}_{3}{ }^{-} / \mathrm{NH}_{4}{ }^{+}$. Os resultados originais foram transformados em $\sqrt{x}$ para se ajustar a distribuição normal. Coeficiente de variação (\%) $=25,1$ (a) e 13,5 (b).

\subsubsection{Atividade de enzimas antioxidantes na parte aérea}

As atividades das enzimas catalase (CAT), guaiacol peroxidase (GPX), ascorbato peroxidase (APX) e glutationa redutase (GR) não foram influenciadas pelas combinações dos fatores testados. As médias das atividades

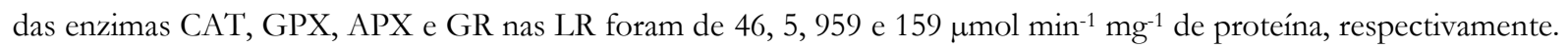
As médias das atividades das enzimas CAT, GPX, APX e GR nos DC da parte aérea foram de 159, 11, 760 e 159 $\mu \mathrm{mol} \mathrm{min} \mathrm{m}^{-1} \mathrm{mg}^{-1}$ de proteína, respectivamente. No entanto, verificou-se que a atividade da SOD nas LR e nos DC da parte aérea apresentaram diferenças na intensidade das bandas. Nas LR do capim tanzânia foram detectadas três isoformas de SOD, sendo a mais visível a isoforma II, cujas bandas mostraram-se mais intensas, o que sugere maior atividade dessa isoforma de SOD (Figura 29). Na isoforma II as bandas foram mais intensas na proporção 70/30 de $\mathrm{NO}_{3}{ }^{-} / \mathrm{NH}_{4}{ }^{+}$e menos intensas na proporção 50/50 de $\mathrm{NO}_{3}{ }^{-} / \mathrm{NH}_{4}{ }^{+}$, especialmente na dose de $\mathrm{Cu}$ de $1000 \mu \mathrm{mol} \mathrm{L}{ }^{-1}$ em que a banda foi praticamente indetectável. Nas isoformas I e III as bandas obtidas nos tecidos das plantas 
crescidas na proporção 100/0 de $\mathrm{NO}_{3}{ }^{-} / \mathrm{NH}_{4}{ }^{+}$parecem ter a mesma intensidade, independente da dose de $\mathrm{Cu}$, mas nas proporções $70 / 30$ e 50/50 de $\mathrm{NO}_{3}{ }^{-} / \mathrm{NH}_{4}{ }^{+}$as bandas são menos intensas. Especialmente na proporção 50/50 de $\mathrm{NO}_{3}{ }^{-} / \mathrm{NH}_{4}{ }^{+}$combinada à dose de $\mathrm{Cu}$ de $1000 \mu \mathrm{mol} \mathrm{L}-1$, a atividade também foi praticamente indetectável (Figura 29).

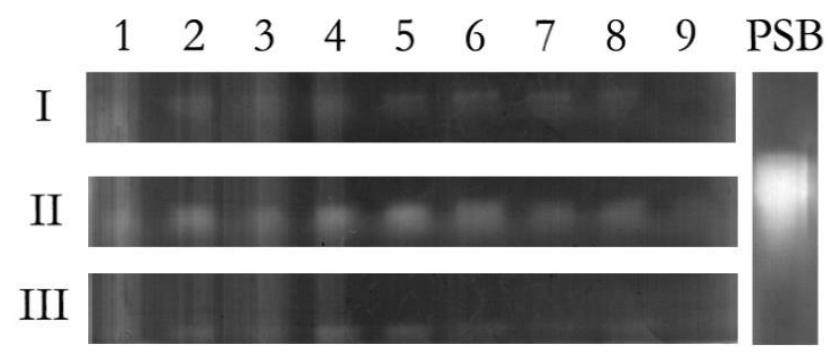

Figura 29. Atividade da enzima superóxido dismutase (SOD) em lâminas diagnósticas do capim tanzânia no primeiro corte, detectada por eletroforese em gel de poliacrilamida em função de doses de $\mathrm{Cu}$ e proporções de $\mathrm{NO}_{3}-\mathrm{NH}_{4}{ }^{+}$em solução nutritiva. I, II e III = isoformas de SOD; 1 a $3=100 / 0$ de $\mathrm{NO}_{3}-/ \mathrm{NH}_{4}{ }^{+} ; 4$ a $6=70 / 30$ de $\mathrm{NO}_{3}{ }^{-} / \mathrm{NH}_{4}{ }^{+} ; 7$ a $9=50 / 50$ de $\mathrm{NO}_{3}{ }^{-} / \mathrm{NH}_{4}{ }^{+} ; 1$, 4 e $7=\mathrm{Cu} 0,3 \mu \mathrm{mol} \mathrm{L}^{-1}$; 2, 5 e $8=\mathrm{Cu} 500 \mu \mathrm{mol} \mathrm{L}^{-1}$; 3, 6 e $9=\mathrm{Cu} 1000 \mu \mathrm{mol} \mathrm{L}^{-1}$; PSB = Padrão de SOD bovino.

Nos DC da parte aérea, as bandas da SOD foram mais visíveis que as constatadas nas LR, sugerindo que essa parte da planta apresenta maior atividade de SOD. Foram detectadas duas isoformas de SOD nos DC da parte aérea, com a mais visível das bandas verificadas na isoforma II, o que sugere maior atividade dessa isoforma de SOD (Figura 30). $\mathrm{Na}$ isoforma I de SOD, as plantas supridas com $\mathrm{N}$ na forma de $\mathrm{NO}_{3}{ }^{-}$apresentaram menor intensidade das bandas nas plantas expostas à dose de $\mathrm{Cu}$ de $1000 \mu \mathrm{mol} \mathrm{L}^{-1}$ em comparação às plantas que receberam $\mathrm{Cu}$ de 0,3 $\mu \mathrm{mol} \mathrm{L}{ }^{-1}$. De forma oposta, nas plantas que receberam 70/30 e 50/50 de $\mathrm{NO}_{3}{ }^{-} / \mathrm{NH}_{4}{ }^{+}$a intensidade da banda foi maior na dose de $\mathrm{Cu}$ de $1000 \mu \mathrm{mol} \mathrm{L} \mathrm{L}^{-1}$ em comparação à dose de $\mathrm{Cu}$ de $0,3 \mu \mathrm{mol} \mathrm{L}-1$ (Figura 30). Na isoforma II, as bandas constatadas nas plantas que receberam 70/30 de $\mathrm{NO}_{3}{ }^{-} / \mathrm{NH}_{4}{ }^{+}$foram intensas, mas tanto as plantas dessa proporção quanto às daquelas supridas com 50/50 de $\mathrm{NO}_{3}{ }^{-} / \mathrm{NH}_{4}{ }^{+}$apresentaram maior intensidade das bandas na dose de $\mathrm{Cu}$ de $1000 \mu \mathrm{mol} \mathrm{L}-1$, comparadas às plantas que receberam $\mathrm{Cu}$ de 0,3 $\mu \mathrm{mol} \mathrm{L}^{-1}$ (Figura 30).

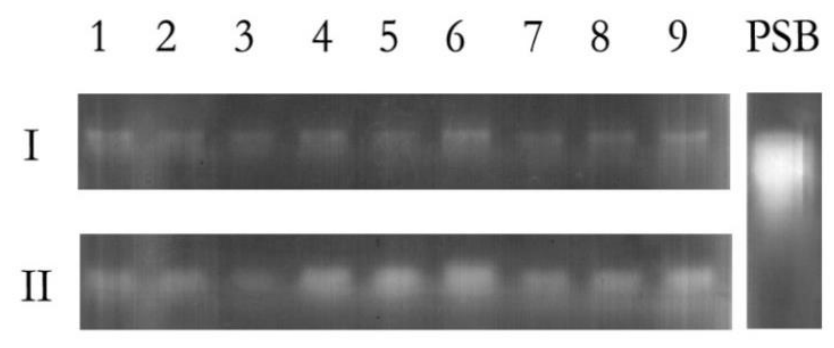

Figura 30. Atividade da enzima superóxido dismutase (SOD) nos demais componentes da parte aérea do capim tanzânia no primeiro corte, detectada por eletroforese em gel de poliacrilamida em função de doses de $\mathrm{Cu}$ e proporções de $\mathrm{NO}_{3}{ }^{-} / \mathrm{NH}_{4}{ }^{+} \mathrm{em}^{-}$ solução nutritiva. I, II e III = isoformas de SOD; 1 a $3=100 / 0$ de $\mathrm{NO}_{3}{ }^{-} / \mathrm{NH}_{4}{ }^{+} ; 4$ a $6=70 / 30$ de $\mathrm{NO}_{3}{ }^{-} / \mathrm{NH}_{4}{ }^{+} ; 7$ a $9=50 / 50$ de $\mathrm{NO}_{3}{ }^{-} / \mathrm{NH}_{4}+$; 1 , 4 e $7=\mathrm{Cu} 0,3 \mu \mathrm{mol} \mathrm{L}-1 ; 2,5$ e $8=\mathrm{Cu} 500 \mu \mathrm{mol} \mathrm{L}^{-1} ; 3,6$ e $9=\mathrm{Cu} 1000 \mu \mathrm{mol} \mathrm{L}^{-1}$; PSB $=$ Padrão de SOD bovino. 


\subsubsection{Segundo corte}

\subsubsection{Acúmulo de Cu na parte aérea e nas raízes}

A interação proporções de $\mathrm{NO}_{3}{ }^{-} / \mathrm{NH}_{4}{ }^{+} \times$doses de $\mathrm{Cu}$ foi significativa para o acúmulo de $\mathrm{Cu}$ na parte aérea do capim. Os acúmulos de $\mathrm{Cu}$ foram maiores nas doses de $\mathrm{Cu}$ de $250 \mu \mathrm{mol} \mathrm{L}{ }^{-1}$ (Figura 31), sendo maior nas plantas supridas com $\mathrm{N}$ na forma de $\mathrm{NO}_{3}^{-}$e menor nas plantas supridas com 50/50 de $\mathrm{NO}_{3}{ }^{-} / \mathrm{NH}_{4}{ }^{+}$. $\mathrm{Na}$ dose de $\mathrm{Cu}$ de 0,3 e $500 \mu \mathrm{mol} \mathrm{L}-1$ não houve diferença no acúmulo de $\mathrm{Cu}$ entre as proporções de $\mathrm{NO}_{3}{ }^{-} / \mathrm{NH}_{4}{ }^{+}$estudadas.

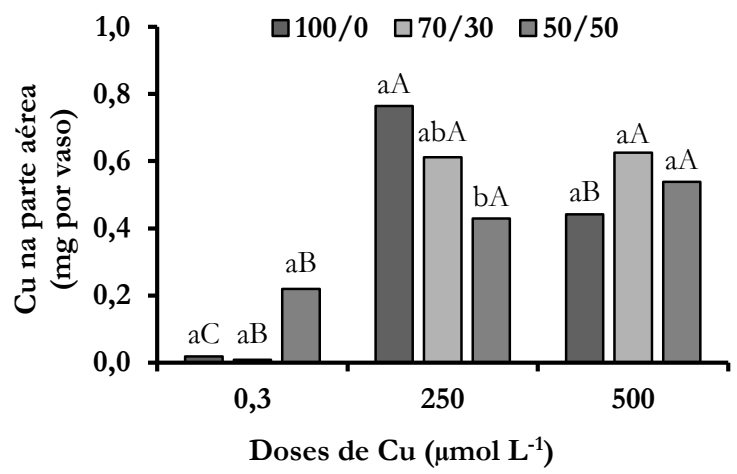

Figura 31. Acúmulo de $\mathrm{Cu}$ na parte aérea do capim tanzânia no segundo corte em função de doses de Cu e proporções de $\mathrm{NO}_{3}{ }^{-} / \mathrm{NH}_{4}{ }^{+}$em solução nutritiva. Letras minúsculas distintas mostram diferença significativa pelo teste de Tukey entre proporções de $\mathrm{NO}_{3}{ }^{-} / \mathrm{NH}_{4}{ }^{+}$dentro de cada dose de $\mathrm{Cu}$ e letras maiúsculas distintas entre as doses de $\mathrm{Cu}$ dentro de cada proporção de $\mathrm{NO}_{3}-\mathrm{NH}_{4}{ }^{+}$. Os resultados originais foram transformados em $\log x$ para se ajustar a distribuição normal. Coeficiente de variação $(\%)=15,3$.

A interação proporções de $\mathrm{NO}_{3}{ }^{-} / \mathrm{NH}_{4}{ }^{+} \times$doses de $\mathrm{Cu}$ foi significativa para o acúmulo de $\mathrm{Cu}$ nas raízes e os resultados indicaram que os maiores acúmulos foram constatados na dose de $\mathrm{Cu}$ de $1000 \mu \mathrm{mol} \mathrm{\textrm {L } ^ { - 1 }} \mathrm{combinadas}$ com as proporções 100/0 e 70/30 de $\mathrm{NO}_{3}{ }^{-} / \mathrm{NH}_{4}{ }^{+}$(Figura 32). $\mathrm{Na}$ dose de $\mathrm{Cu}$ de $500 \mu \mathrm{mol} \mathrm{L}-1$ o acúmulo desse metal nas raízes foi maior nas plantas tratadas com $\mathrm{N}$ exclusivamente na forma de $\mathrm{NO}_{3}{ }^{-}$(Figura 32).

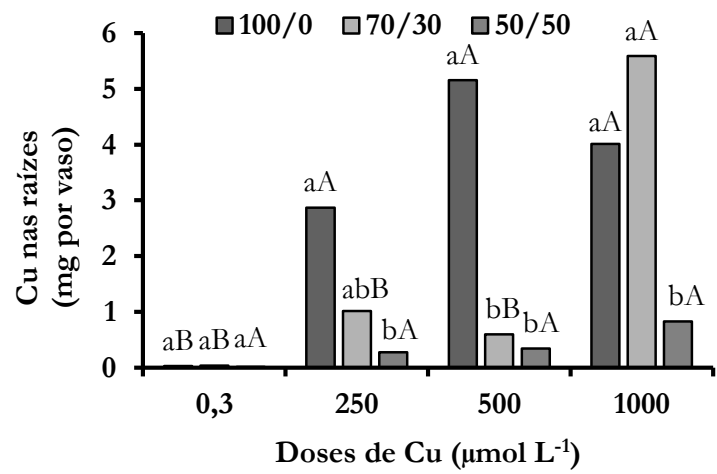

Figura 32. Acúmulo de $\mathrm{Cu}$ nas raízes do capim tanzânia em função de doses de $\mathrm{Cu}$ e proporções de $\mathrm{NO}_{3}-\mathrm{NH}_{4}{ }^{+}$em solução nutritiva. Letras minúsculas distintas mostram diferença significativa pelo teste de Tukey entre proporções de $\mathrm{NO}_{3}{ }^{-} / \mathrm{NH}_{4}{ }^{+}$dentro de cada dose de $\mathrm{Cu}$ e letras maiúsculas distintas entre as doses de $\mathrm{Cu}$ dentro de cada proporção de $\mathrm{NO}_{3}{ }^{-} / \mathrm{NH}_{4}{ }^{+}$. Os resultados originais foram transformados em $\sqrt{x}$ para se ajustar a distribuição normal. Coeficiente de variação $(\%)=25,5$. 
Nas plantas supridas com $\mathrm{N}$ na forma de $\mathrm{NO}_{3}{ }^{-}$, as médias dos acúmulos de $\mathrm{Cu}$ nas doses de $\mathrm{Cu}$ de 250 , 500 e $1000 \mu \mathrm{mol} \mathrm{L}-1$ foram similares e maiores do que na dose de $\mathrm{Cu}$ de $0,3 \mu \mathrm{mol} \mathrm{L}{ }^{-1}$, enquanto que nas plantas supridas com 70/30 de $\mathrm{NO}_{3}{ }^{-} / \mathrm{NH}_{4}{ }^{+} \mathrm{o}$ acúmulo de $\mathrm{Cu}$ foi maior na dose de $\mathrm{Cu}$ de $1000 \mu \mathrm{mol} \mathrm{L}^{-1}$ comparada às demais doses de $\mathrm{Cu}$ (Figura 32). Nas plantas tratadas com 50/50 de $\mathrm{NO}_{3}{ }^{-} / \mathrm{NH}_{4}{ }^{+}$as doses de $\mathrm{Cu}$ não interferiram no acúmulo desse metal nas raízes (Figura 32).

\subsubsection{Indicadores de estresse oxidativo na parte aérea e nas raízes}

A interação proporções de $\mathrm{NO}_{3}{ }^{-} / \mathrm{NH}_{4}{ }^{+} \times$doses de $\mathrm{Cu}$ não foi significativa para a concentração de MDA nas LR do capim, sendo significativo o fator proporções $\mathrm{NO}_{3}{ }^{-} / \mathrm{NH}_{4}{ }^{+}$. A concentração de MDA nas LR das plantas recebendo 50/50 de $\mathrm{NO}_{3}{ }^{-} / \mathrm{NH}_{4}{ }^{+}$foi menores que a constatada nas plantas supridas com $\mathrm{N}$ exclusivo na forma de $\mathrm{NO}_{3}{ }^{-}$(Figura 33a). Para a concentração de MDA nos DC da parte aérea, verificou-se que a interação proporções de $\mathrm{NO}_{3}{ }^{-} / \mathrm{NH}_{4}{ }^{+} \times$doses de $\mathrm{Cu}$ foi significativa e os resultados mostraram que essa concentração na proporção 70/30 de $\mathrm{NO}_{3}{ }^{-} / \mathrm{NH}_{4}{ }^{+}$foi influenciada pelas doses de $\mathrm{Cu}$, com os menores valores constatados nas doses de $\mathrm{Cu}$ de 500 $\mu \mathrm{mol} \mathrm{L}-1$ e os maiores na dose de $\mathrm{Cu}$ de $0,3 \mu \mathrm{mol} \mathrm{L}-1$ (Figura 33b). Nas proporções $100 / 0$ e $50 / 50$ de $\mathrm{NO}_{3}{ }^{-} / \mathrm{NH}_{4}{ }^{+}$, as doses de $\mathrm{Cu}$ não afetaram a concentração de MDA nos DC da parte aérea (Figura 33b). A concentração de $\mathrm{H}_{2} \mathrm{O}_{2}$ não foi influenciada pela combinação dos fatores estudados.
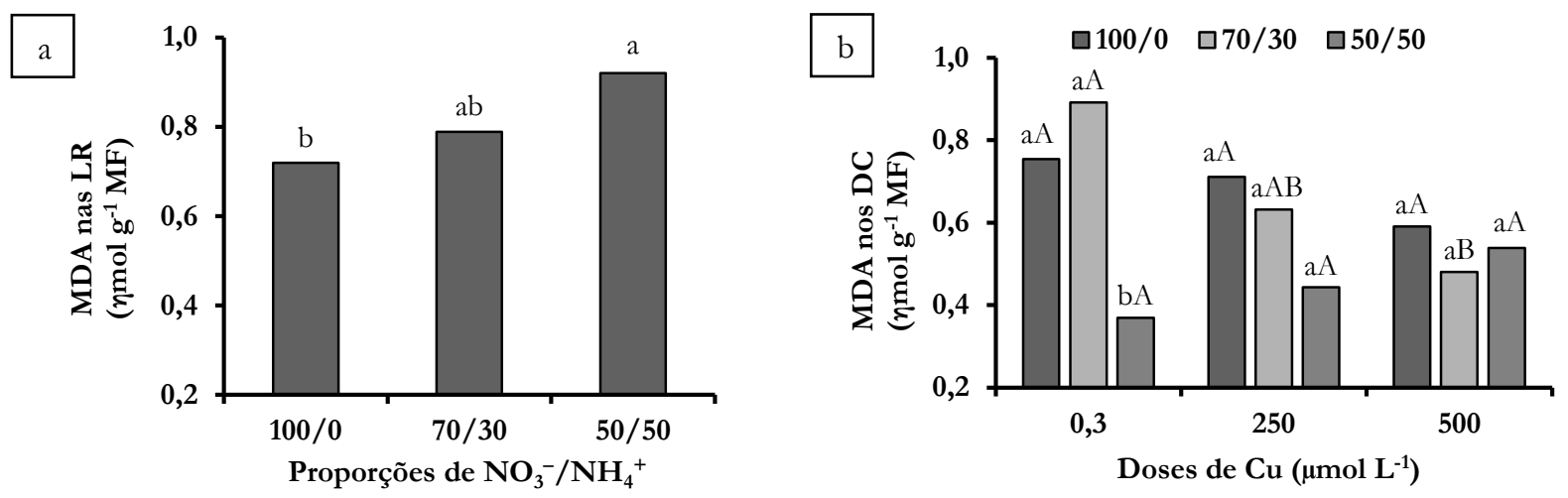

Figura 33. Concentração de malondialdeído (MDA) nas lâminas diagnósticas (LR) em função de proporções de $\mathrm{NO}_{3}{ }^{-} / \mathrm{NH}_{4}{ }^{+}$(a) e concentração de MDA nos demais componentes (DC) da parte aérea em função de doses de Cu e proporções de $\mathrm{NO}_{3}{ }^{-} / \mathrm{NH}_{4}{ }^{+}$ (b) no segundo corte do capim tanzânia cultivado em solução nutritiva. Na figura 33a, letras minúsculas distintas mostram diferença significativa pelo teste de Tukey. Na figura 33b, letras minúsculas distintas mostram diferença significativa pelo teste de Tukey entre proporções de $\mathrm{NO}_{3}-\mathrm{NH}_{4}{ }^{+}$dentro de cada dose de $\mathrm{Cu}$ e letras maiúsculas distintas entre as doses de Cu dentro de cada proporção de $\mathrm{NO}_{3}{ }^{-} / \mathrm{NH}_{4}{ }^{+}$. Os resultados originais da Figura 33b foram transformados em $\sqrt{x}$ para se ajustar a distribuição normal. Coeficiente de variação $(\%)=16,9$ (a) e 11,7 (b).

Para a concentração de MDA nas raízes do capim a interação proporções de $\mathrm{NO}_{3}{ }^{-} / \mathrm{NH}_{4}{ }^{+} \times$doses de $\mathrm{Cu}$ não foi significativa. As doses de $\mathrm{Cu}$ isoladamente foram significativas e os resultados se ajustaram ao modelo exponencial, mostrando que os menores valores foram encontrados nas mais baixas doses de Cu (Figura 34a). Para a concentração de $\mathrm{H}_{2} \mathrm{O}_{2}$ também foi verificado que a interação proporções de $\mathrm{NO}_{3}{ }^{-} / \mathrm{NH}_{4}{ }^{+} \times$doses de $\mathrm{Cu}$ não foi significativa, sendo a variável influenciada pelas proporções de $\mathrm{NO}_{3}{ }^{-} / \mathrm{NH}_{4}{ }^{+}$. Os resultados indicaram que a concentração de $\mathrm{H}_{2} \mathrm{O}_{2}$ foi maior nas raízes de plantas recebendo as proporções 70/30 e 50/50 de $\mathrm{NO}_{3}{ }^{-} / \mathrm{NH}_{4}{ }^{+}$do que nas plantas que receberam 100\% do $\mathrm{N}$ na forma de $\mathrm{NO}_{3}^{-}$(Figura 34b). 

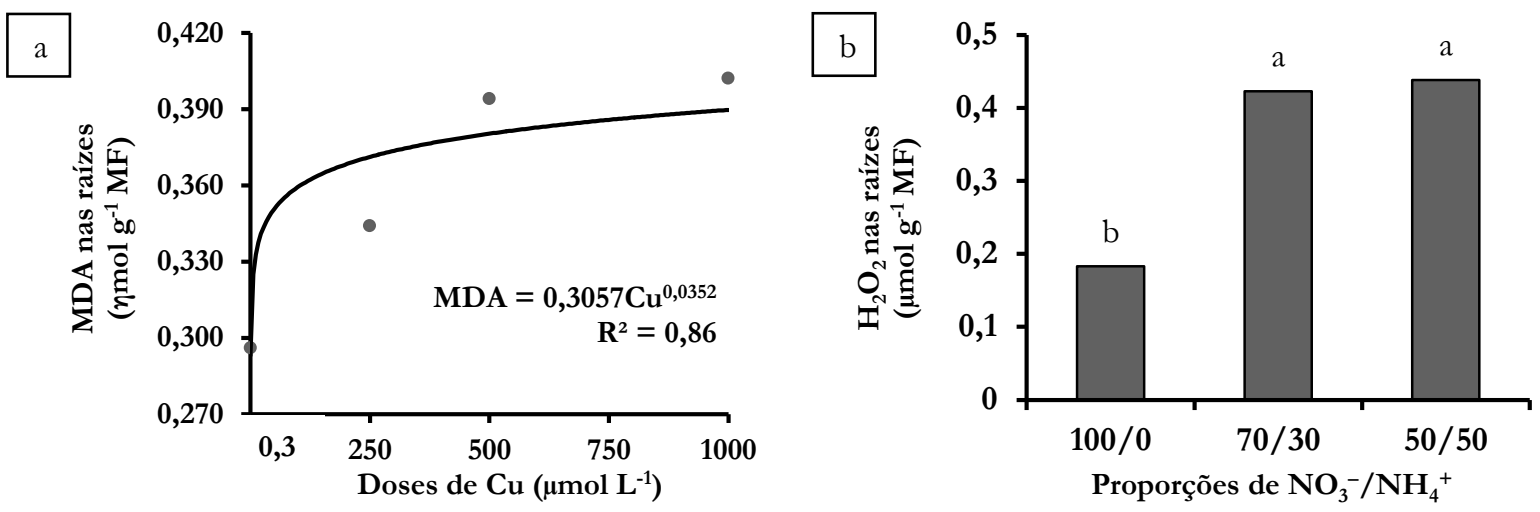

Figura 34. Concentração de malondialdeído (MDA) nas raízes em função de doses de $\mathrm{Cu}$ (a) e concentração de $\mathrm{H}_{2} \mathrm{O}_{2}$ nas raízes em função de doses de $\mathrm{Cu}$ e proporções de $\mathrm{NO}_{3}-\mathrm{NH}_{4}{ }^{+}$(b) no segundo corte do capim tanzânia cultivado em solução nutritiva. $\mathrm{Na}$ figura 34b, letras minúsculas distintas mostram diferença significativa pelo teste de Tukey. Os resultados originais da Figura 34b foram transformados em $\log x$ para se ajustar a distribuição normal. Coeficiente de variação (\%) = 27,4 (a) e 53,0 (b).

\subsubsection{Atividade fotossintética nas lâminas diagnósticas}

A interação proporções de $\mathrm{NO}_{3}{ }^{-} / \mathrm{NH}_{4}{ }^{+} \times$doses de $\mathrm{Cu}$ não foi significativa para os atributos fotossintéticos, sendo significativa na taxa de assimilação de $\mathrm{CO}_{2}$, condutância estomática, eficiência quântica do fotossistema II e taxa de transporte de elétrons as doses de Cu isoladas (Figura 35).
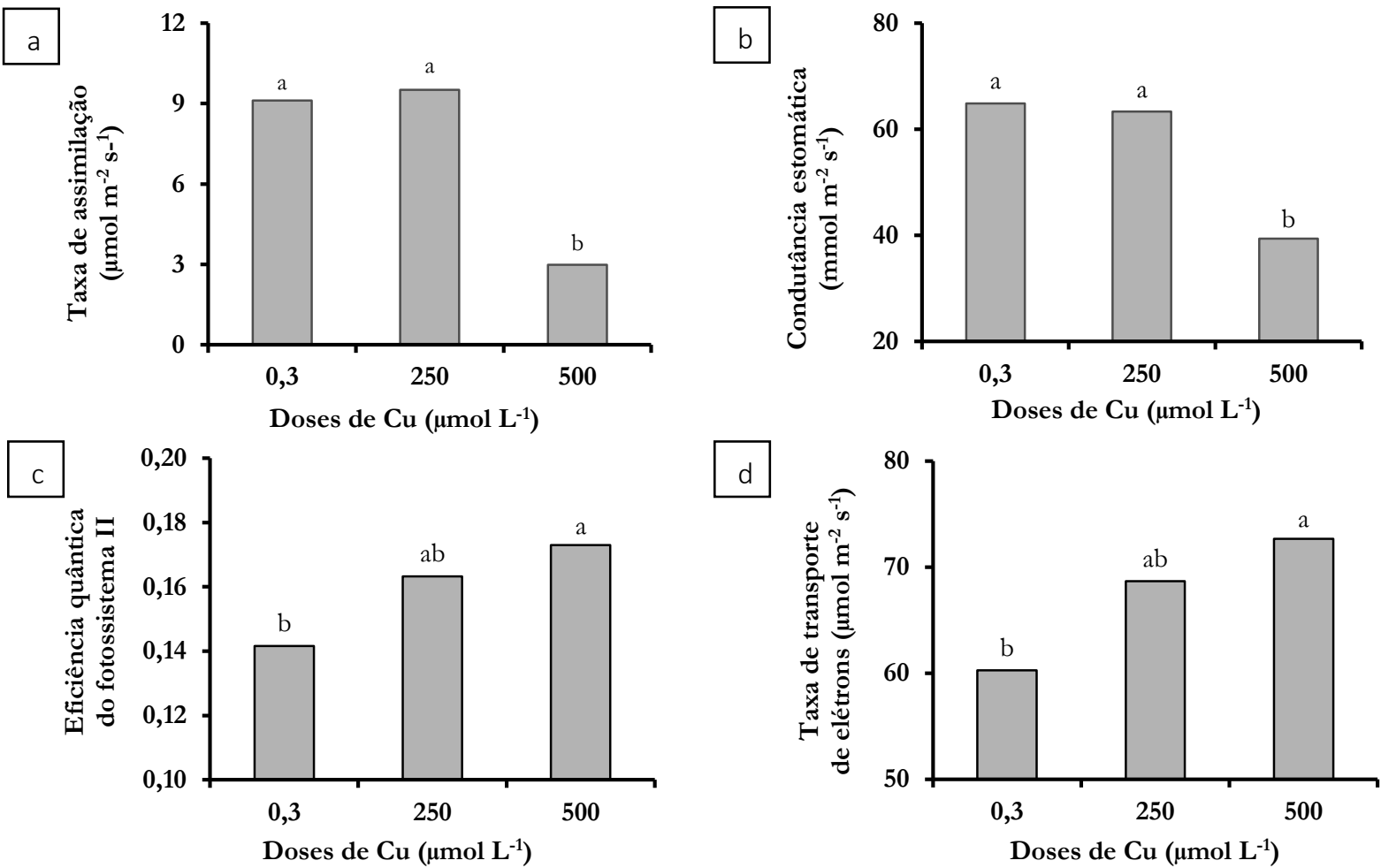

Figura 35. Taxa de assimilação (Figura 35a), condutância estomática (Figura 35b), eficiência do fotossistema II (Figura 35c) e taxa de transporte de elétrons (Figura 35d) em função de doses de Cu residual no segundo corte do capim tanzânia cultivado em solução nutritiva. Letras minúsculas diferentes mostram diferença significativa $(\mathrm{p}<0,05)$ pelo teste de Tukey. Coeficiente de variação $(\%)=35,0$ (Figura 35a), 33,3 (Figura 35b), 14,2 (Figura 35c) e 14,2 (Figura 35d). 
Para a taxa de assimilação de $\mathrm{CO}_{2}$ (Figura 35a) e condutância estomática (Figura 35b) menores valores foram observados na dose de $\mathrm{Cu}$ de $500 \mu \mathrm{mol} \mathrm{L}^{-1}$ do que nas doses de $\mathrm{Cu}$ de 0,3 e $250 \mu \mathrm{mol} \mathrm{L}^{-1}$. Quanto à eficiência quântica do fotossistema II (Figura 35c) e a taxa de transporte de elétrons (Figura 35d) do capim, as médias desses atributos na dose de $\mathrm{Cu}$ de $500 \mu \mathrm{mol} \mathrm{L}-1$ foram maiores que na dose de $\mathrm{Cu}$ de $0,3 \mu \mathrm{mol} \mathrm{L} \mathrm{L}^{-1}$.

\subsubsection{Concentração de prolina na parte aérea e nas raízes}

A interação proporções de $\mathrm{NO}_{3}{ }^{-} / \mathrm{NH}_{4}{ }^{+} \times$doses de $\mathrm{Cu}$ foi significativa para a concentração de prolina nas LR do capim, sendo a concentração desse aminoácido nos DC da parte aérea do capim influenciados apenas pelas proporções de $\mathrm{NO}_{3}^{-} / \mathrm{NH}_{4}{ }^{+}$isoladamente. $\mathrm{Na}$ dose de $\mathrm{Cu}$ de $1000 \mu \mathrm{mol} \mathrm{L}{ }^{-1}$ a concentração de prolina não diferiu entre as proporções de $\mathrm{NO}_{3}-/ \mathrm{NH}_{4}{ }^{+}$, enquanto na dose de $\mathrm{Cu}$ de $0,3 \mu \mathrm{mol} \mathrm{L}-1$ a maior concentração foi verificada nas plantas com 50/50 de $\mathrm{NO}_{3}{ }^{-} / \mathrm{NH}_{4}{ }^{+}$e a menor nas demais proporções de $\mathrm{NO}_{3}{ }^{-} / \mathrm{NH}_{4}{ }^{+}$(Figura 36a). As plantas recebendo $70 / 30$ de $\mathrm{NO}_{3}{ }^{-} / \mathrm{NH}_{4}{ }^{+}$não apresentaram variação na concentração de prolina nas $\mathrm{LR}$ em função das doses de $\mathrm{Cu}$ (Figura 36a). A concentração de prolina nos DC da parte aérea do capim foi influenciada pelas proporções de $\mathrm{NO}_{3}{ }^{-} / \mathrm{NH}_{4}{ }^{+}$e a maior concentração desse aminoácido foi constatada nas plantas que receberam $50 / 50$ de $\mathrm{NO}_{3}-/ \mathrm{NH}_{4}{ }^{+}$e as menores nas plantas que receberam 100/0 e 70/30 de $\mathrm{NO}_{3}{ }^{-} / \mathrm{NH}_{4}{ }^{+}$, sendo os valores similares nestas duas últimas proporções de $\mathrm{NO}_{3}-/ \mathrm{NH}_{4}{ }^{+}$(Figura 36b).
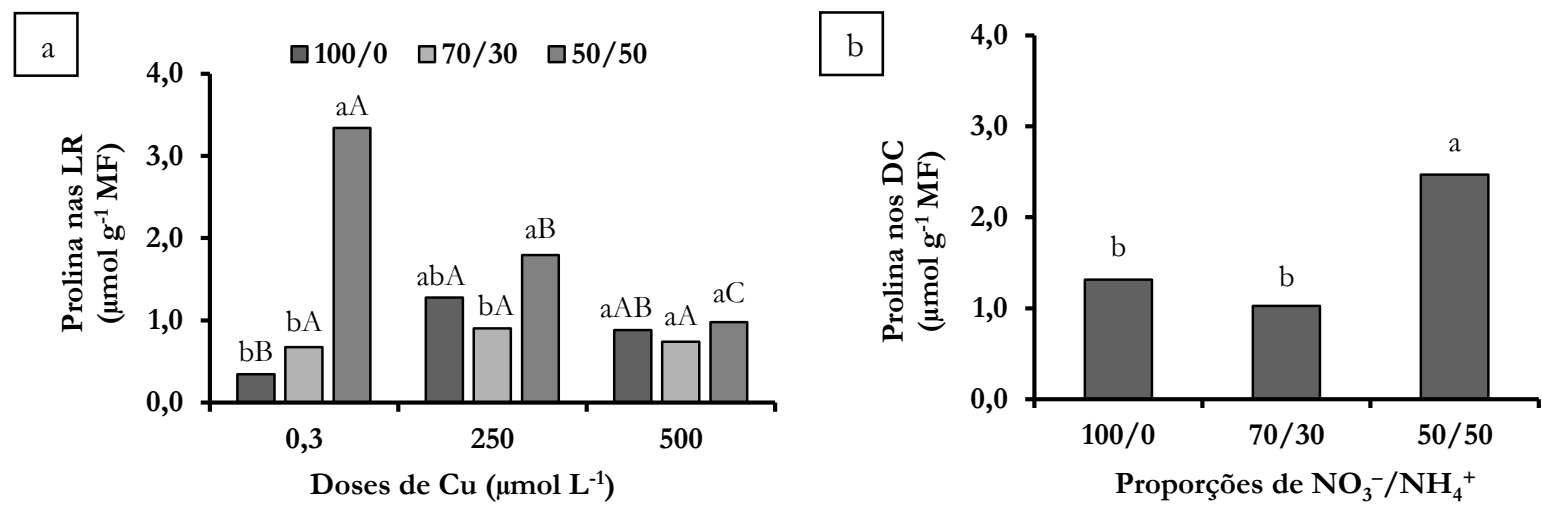

Figura 36. Concentração de prolina nas lâminas diagnósticas (LR) em função de doses de $\mathrm{Cu}$ e proporções de $\mathrm{NO}_{3}^{-} / \mathrm{NH}_{4}{ }^{+}$(a) e concentração de prolina nos demais componentes (DC) da parte aérea em função de proporções de $\mathrm{NO}_{3}{ }^{-} / \mathrm{NH}_{4}{ }^{+}$(b), no segundo corte do capim tanzânia cultivado em solução nutritiva. Na figura 36a, letras minúsculas distintas mostram diferença significativa pelo teste de Tukey entre proporções de $\mathrm{NO}_{3}-\mathrm{NH}_{4}{ }^{+}$dentro de cada dose de $\mathrm{Cu}$ e letras maiúsculas distintas entre as doses de $\mathrm{Cu}$ dentro de cada proporção de $\mathrm{NO}_{3}{ }^{-} / \mathrm{NH}_{4}{ }^{+}$. Na figura 36b, letras minúsculas distintas mostram diferença significativa pelo teste de Tukey. Os resultados originais foram transformados em $\sqrt{x}$ para se ajustar a distribuição normal. Coeficiente de variação $(\%)=$ 21,6 (a) e 18,4 (b).

\subsubsection{Atividade de enzimas antioxidante nas partes da planta}

As atividades da SOD nas LR (Figura 37) e DC da parte aérea (Figura 38) apresentaram diferenças nas intensidades das bandas das isoformas I e II, sendo a atividade das duas bandas de SOD nas LR pouco visíveis e nos DC da parte aérea muito visíveis. Na isoforma I detectada nas LR, a banda foi mais intensa nas plantas submetidas ao $\mathrm{Cu}$ de $0,3 \mu \mathrm{mol} \mathrm{L} \mathrm{L}^{-1}$ e, à medida que se elevaram as doses de $\mathrm{Cu}$, as bandas apresentaram menor intensidade, tornando-se praticamente indetectável na dose de $\mathrm{Cu}$ de $500 \mu \mathrm{mol} \mathrm{L}^{-1}$ (Figura 37). Na isoforma II, as bandas foram 


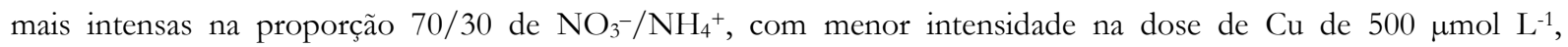
enquanto na proporção 50/50 de $\mathrm{NO}_{3}{ }^{-} / \mathrm{NH}_{4}{ }^{+}$a banda foi mais intensa na dose de $\mathrm{Cu}$ de $500 \mu \mathrm{mol} \mathrm{L}{ }^{-1}$ e menos intensa nas doses de $\mathrm{Cu}$ de 0,3 e $250 \mu \mathrm{mol} \mathrm{L}{ }^{-1}$ nas LR (Figura 37). Nota-se ainda que nas isoformas I e II, a proporção 100/0 de $\mathrm{NO}_{3}^{-} / \mathrm{NH}_{4}{ }^{+}$proporcionou menor intensidade das bandas nas LR do capim (Figura 37).

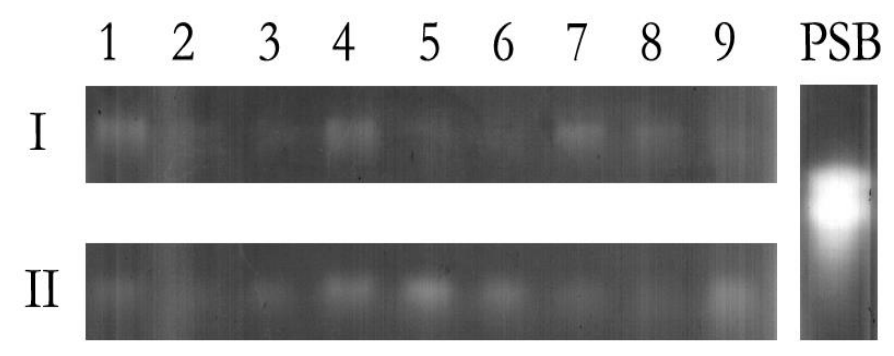

Figura 37. Atividade da enzima superóxido dismutase (SOD) em lâminas diagnósticas do capim tanzânia no segundo corte, detectada por eletroforese em gel de poliacrilamida em função de doses de $\mathrm{Cu}$ e proporções de $\mathrm{NO}_{3}-\mathrm{NH}_{4}{ }^{+}$em solução nutritiva. I e II $=$ isoformas de SOD; 1 a $3=100 / 0 \mathrm{de} \mathrm{NO}_{3}{ }^{-} / \mathrm{NH}_{4}{ }^{+} ; 4$ a $6=70 / 30 \mathrm{de} \mathrm{NO}_{3}{ }^{-} / \mathrm{NH}_{4}{ }^{+} ; 7$ a $9=50 / 50 \mathrm{de} \mathrm{NO}_{3}^{-} / \mathrm{NH}_{4}{ }^{+} ; 1,4 \mathrm{e}$ $7=\mathrm{Cu} 0,3 \mu \mathrm{mol} \mathrm{L}{ }^{-1} ; 2,5$ e $8=\mathrm{Cu} 250 \mu \mathrm{mol} \mathrm{L}^{-1} ; 3,6$ e $9=\mathrm{Cu} 500 \mu \mathrm{mol} \mathrm{L}^{-1}$; PSB = Padrão de SOD bovino.

Para a atividade da SOD nos DC da parte aérea do capim tanzânia, foram detectados duas isoformas de SOD, sendo a isoforma II claramente visível, o que indica maior atividade dessa isoforma (Figura 38). Na isoforma I, as plantas recebendo proporção 70/30 e especialmente com a proporção 50/50 de $\mathrm{NO}_{3}{ }^{-} / \mathrm{NH}_{4}{ }^{+}$, expostas à dose de $\mathrm{Cu}$ de $500 \mu \mathrm{mol} \mathrm{L}{ }^{-1}$, claramente apresentaram maior intensidade da banda (Figura 38). Na isoforma II, as bandas foram mais intensas e destacadas, possibilitando verificar maior intensidade das bandas na proporção 70/30 e 50/50 de $\mathrm{NO}_{3}{ }^{-} / \mathrm{NH}_{4}{ }^{+}$combinadas às doses de $\mathrm{Cu}$ de 250 e $500 \mu \mathrm{mol} \mathrm{L}{ }^{-1}$, em comparação às bandas das plantas crescidas com $\mathrm{Cu}$ de $0,3 \mu \mathrm{mol} \mathrm{L}-1$ (Figura 38). Na proporção 100/0 de $\mathrm{NO}_{3}-/ \mathrm{NH}_{4}{ }^{+}$notou-se que as bandas das isoformas I e

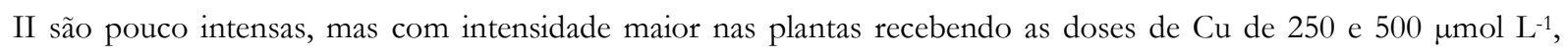
comparadas à dose de $\mathrm{Cu}$ de $0,3 \mu \mathrm{mol} \mathrm{L}{ }^{-1}$ (Figura 38).

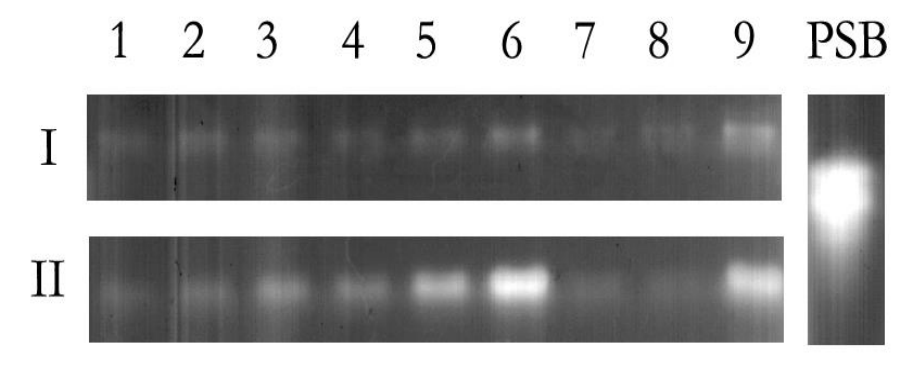

Figura 38. Atividade da enzima superóxido dismutase (SOD) nos demais componentes da parte aérea do capim tanzânia no segundo corte, detectada por eletroforese em gel de poliacrilamida em função de doses de Cu e proporções de $\mathrm{NO}_{3}^{-} / \mathrm{NH}_{4}{ }^{+} \mathrm{em}$ solução nutritiva. I e II = isoformas de SOD; 1 a $3=100 / 0$ de $\mathrm{NO}_{3}{ }^{-} / \mathrm{NH}_{4}{ }^{+} ; 4$ a $6=70 / 30 \mathrm{de} \mathrm{NO}_{3}{ }^{-} / \mathrm{NH}_{4}{ }^{+} ; 7$ a $9=50 / 50$ de $\mathrm{NO}_{3}^{-} / \mathrm{NH}_{4}^{+} ; 1$, 4 e $7=\mathrm{Cu} 0,3 \mu \mathrm{mol} \mathrm{L}^{-1} ; 2,5$ e $8=\mathrm{Cu} 250 \mu \mathrm{mol} \mathrm{L}^{-1} ; 3,6$ e $9=\mathrm{Cu} 500 \mu \mathrm{mol} \mathrm{L}^{-1}$; PSB = Padrão de SOD bovino.

No que diz respeito à atividade das enzimas CAT, APX e GR nas LR do capim, verificou-se que a interação proporções de $\mathrm{NO}_{3}{ }^{-} / \mathrm{NH}_{4}{ }^{+} \times$doses de $\mathrm{Cu}$ não foi significativa, enquanto as doses de $\mathrm{Cu}$ isoladas influenciaram essas varáveis (Figura 39). As atividades dessas enzimas, juntamente com a GPX, nos DC da parte aérea não foram influenciadas pelas combinações estudadas. As atividades das enzimas CAT (Figura 39a), APX (Figura 39b) e GR (Figura 39c) apresentaram padrão similar, sendo verificado que as atividades dessas enzimas foram 
menores e similares nas doses de $\mathrm{Cu}$ de 250 e $500 \mu \mathrm{mol} \mathrm{L}^{-1}$ e maiores na dose de $\mathrm{Cu}$ de $0,3 \mu \mathrm{mol} \mathrm{L}{ }^{-1}$. A atividade da enzima GPX nas LR do capim não variou significativamente em função das combinações testadas.
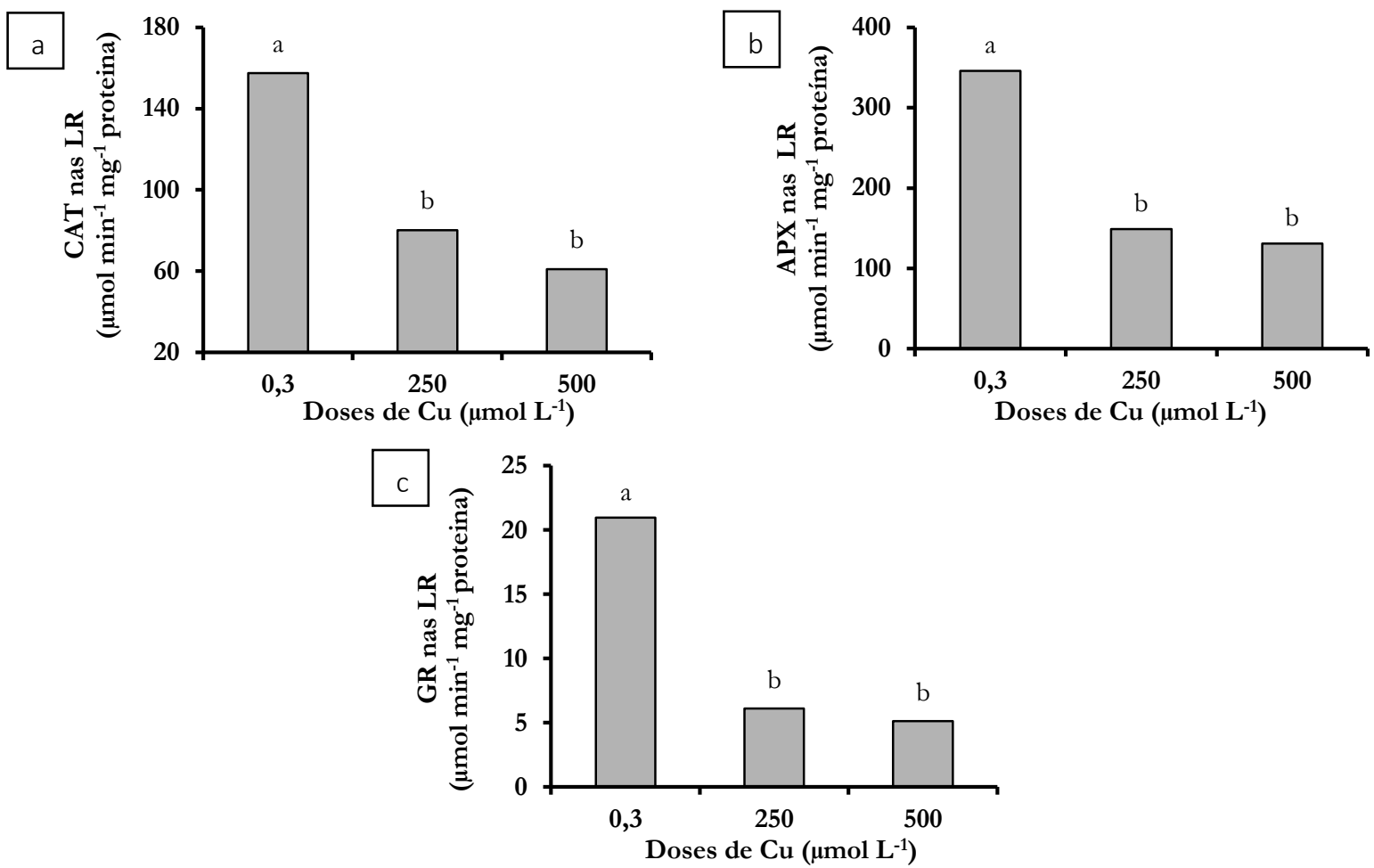

Figura 39. Atividade das enzimas catalase (CAT, Figura 39a), ascorbato peroxidase (APX, Figura 39b) e glutationa redutase (GR, Figura 39c) nas folhas diagnósticas do capim tanzânia em função de doses de $\mathrm{Cu}$ residual no segundo corte em solução nutritiva. Letras minúsculas diferentes mostram variação significativa $(\mathrm{p}<0,05)$ pelo teste de Tukey. Os dados foram transformados para se ajustar a distribuição normal. Coeficiente de variação (\%) = 24,1 (Figura 39a), 26,8 (Figura 39b) e 15,2 (Figura 39c).

Identificaram-se duas isoformas de SOD nas raízes, as quais apresentaram diferenças na intensidade das bandas, especialmente na isoforma II (Figura 40), o que sugere maior atividade dessa isoforma de SOD nessa parte da planta. $\mathrm{Na}$ isoforma I, a banda foi mais destacada na proporção $70 / 30$ de $\mathrm{NO}_{3}{ }^{-} / \mathrm{NH}_{4}{ }^{+}$, que combinada à mais elevada dose de $\mathrm{Cu}$ de $1000 \mu \mathrm{mol} \mathrm{L} \mathrm{L}^{-1}$ proporcionou a banda mais intensa e na dose de $\mathrm{Cu}$ de $0,3 \mu \mathrm{mol} \mathrm{L}^{-1}$ menos intensa. $\mathrm{Na}$ isoforma I, na proporção $100 / 0$ de $\mathrm{NO}_{3}{ }^{-} / \mathrm{NH}_{4}{ }^{+}$verificou-se que a banda foi menos intensa na dose de $\mathrm{Cu}$ de $1000 \mu \mathrm{mol} \mathrm{L} \mathrm{L}^{-1}$ e mais intensa na dose de $\mathrm{Cu}$ de $0,3 \mu \mathrm{mol} \mathrm{L} \mathrm{L}^{-1}$. Na proporção 50/50 de $\mathrm{NO}_{3}^{-} / \mathrm{NH}_{4}{ }^{+}$ocorreu alteração na intensidade da banda quando as plantas foram expostas à dose de $\mathrm{Cu}$ de $1000 \mu \mathrm{mol} \mathrm{L} \mathrm{L}^{-1}$, sendo mais intensa em comparação com as demais doses de Cu (Figura 40). Na isoforma II, as bandas foram claramente mais destacadas, especialmente nas doses de $\mathrm{Cu}$ de 500 e $1000 \mu \mathrm{mol} \mathrm{L}^{-1}$ combinadas às proporções de 70/30 e 50/50 de $\mathrm{NO}_{3}{ }^{-} / \mathrm{NH}_{4}{ }^{+}$, que foram muito mais intensas do que nas plantas crescidas com $\mathrm{Cu}$ de $0,3 \mu \mathrm{mol} \mathrm{L}{ }^{-1}$. Esse efeito também ocorreu na proporção 100/0 de $\mathrm{NO}_{3}^{-} / \mathrm{NH}_{4}{ }^{+}$, mas em menor intensidade. 


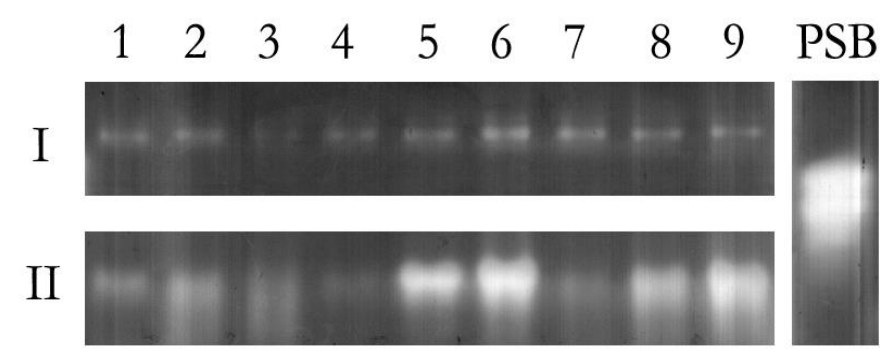

Figura 40. Atividade da enzima superóxido dismutase $(\mathrm{SOD})$ nas raízes do capim tanzânia no segundo corte, detectada por eletroforese em gel de poliacrilamida em função de doses de $\mathrm{Cu}$ e proporções de $\mathrm{NO}_{3}-\mathrm{NH}_{4}{ }^{+}$em solução nutritiva. I e II = isoformas de SOD; 1 a $3=100 / 0$ de $\mathrm{NO}_{3}^{-} / \mathrm{NH}_{4}{ }^{+} ; 4$ a $6=70 / 30$ de $\mathrm{NO}_{3}^{-} / \mathrm{NH}_{4}{ }^{+} ; 7$ a $9=50 / 50 \mathrm{de} \mathrm{NO}_{3}^{-} / \mathrm{NH}_{4}{ }^{+} ; 1,4$ e $7=\mathrm{Cu}$ $0,3 \mu \mathrm{mol} \mathrm{L}-1$; 2, 5 e $8=\mathrm{Cu} 500 \mu \mathrm{mol} \mathrm{L}-1 ; 3,6$ e $9=\mathrm{Cu} 1000 \mu \mathrm{mol} \mathrm{L}^{-1} ;$ PSB $=$ Padrão de SOD bovino.

Para as atividades das enzimas CAT, GPX, APX e GR no sistema radicular do capim, foi verificado que a interação proporções de $\mathrm{NO}_{3}{ }^{-} / \mathrm{NH}_{4}{ }^{+} \times$doses de $\mathrm{Cu}$ não foi significativa, mas as doses de $\mathrm{Cu}$ influenciaram significativamente essas variáveis (Figura 41). Os resultados para a atividade da enzima CAT se ajustaram ao modelo quadrático, sendo a atividade da CAT tão maior quanto mais elevada à dose de Cu a partir de $500 \mu \mathrm{mol} \mathrm{L}^{-1}$ (Figura 41a). Os resultados da atividade da GPX se ajustaram ao modelo linear, o que significa ser essa atividade tão maior quanto mais elevada à dose de Cu (Figura 41b). Para a atividade da APX houve ajuste dos resultados ao modelo linear, ou seja, os valores dessa atividade foram tão mais altos quanto mais elevada foi à dose de Cu (Figura 41c). No caso da atividade da enzima GR os resultados se ajustaram ao modelo quadrático e a atividade foi tão maior quanto mais elevada à dose de $\mathrm{Cu}$ a partir da dose de Cu de $500 \mu \mathrm{mol} \mathrm{L}^{-1}$ (Figura 41d).
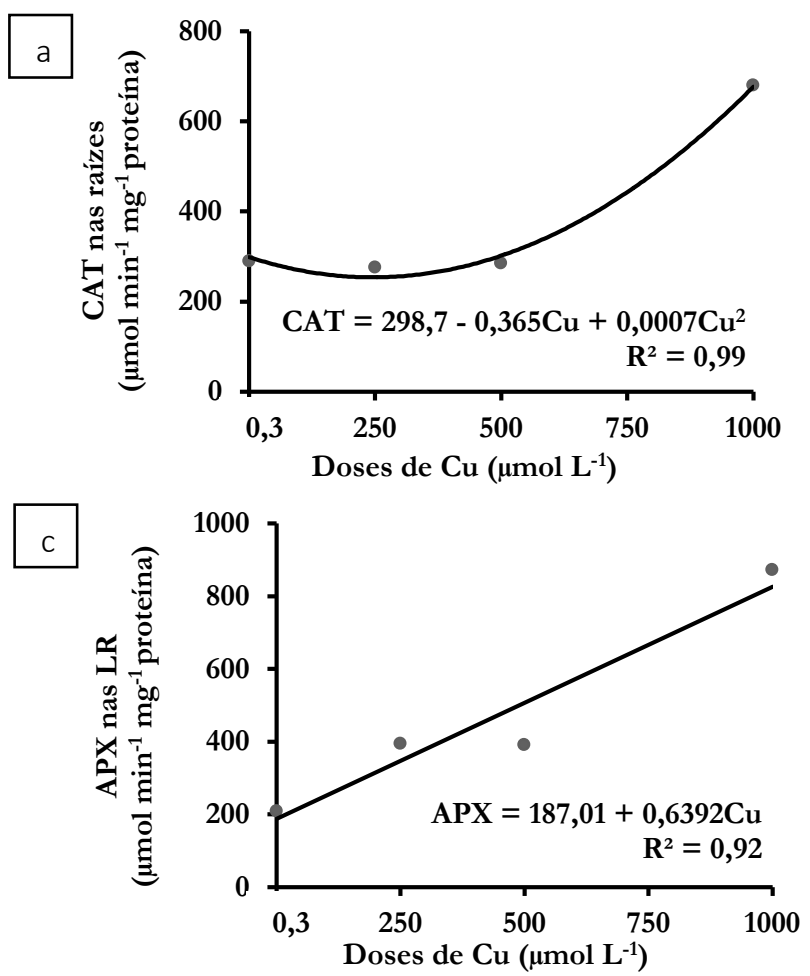
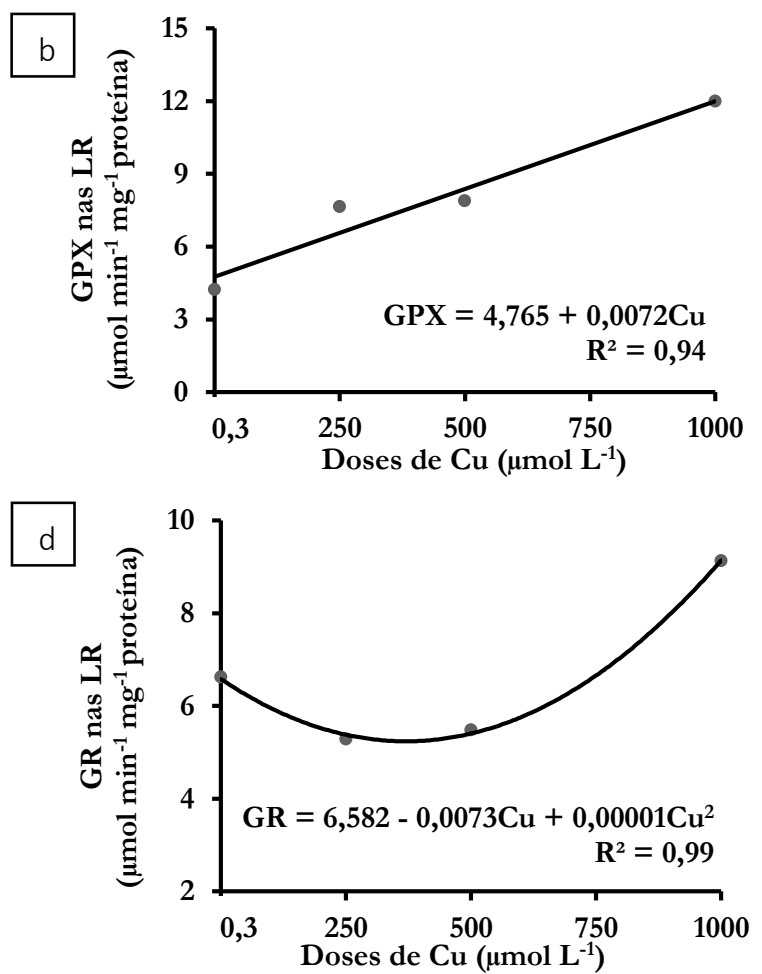

Figura 41. Atividade das enzimas catalase (CAT, a), guaiacol peroxidase (GPX, b), ascorbato peroxidase (APX, c) e glutationa redutase $(\mathrm{GR}, \mathrm{d})$ nas raízes do capim tanzânia no segundo corte em função de doses de $\mathrm{Cu}$ em solução nutritiva. Letras minúsculas distintas mostram diferença significativa pelo teste de Tukey. Os resultados originais foram transformados em $\log x$ para se ajustar a distribuição normal. Coeficiente de variação (\%) = 4,8 (a), 21,6 (b), 29,6 (c) e 3,5 (d). 


\subsection{Discussão}

O maior acúmulo de $\mathrm{Cu}$ nas raízes das plantas que receberam a proporção $70 / 30$ de $\mathrm{NO}_{3}{ }^{-} / \mathrm{NH}_{4}{ }^{+}$ocorreu somente na dose de $\mathrm{Cu}$ de $1000 \mu \mathrm{mol} \mathrm{L}{ }^{-1}$, enquanto nas plantas supridas com N exclusivamente na forma de $\mathrm{NO}_{3}^{-} \mathrm{o}$ acúmulo foi incrementado a partir da dose de $\mathrm{Cu}$ de $250 \mu \mathrm{mol} \mathrm{L} \mathrm{L}^{-1}$. Isso significa que a inclusão de $30 \%$ do $\mathrm{N}$ na forma de $\mathrm{NH}_{4}{ }^{+}$facilitou o transporte do excesso de $\mathrm{Cu}$ das raízes para a parte aérea durante o primeiro crescimento do capim tanzânia, enquanto que o suprimento com $\mathrm{N}$ na forma de $\mathrm{NO}_{3}{ }^{-}$dificultou esse transporte. Isso explica o acúmulo de $\mathrm{Cu}$ na parte aérea do capim tanzânia crescido em solução nutritiva contendo a proporção de 70/30 de $\mathrm{NO}_{3}{ }^{-} / \mathrm{NH}_{4}{ }^{+}$ter sido maior do que nas demais proporções de $\mathrm{NO}_{3}{ }^{-} / \mathrm{NH}_{4}{ }^{+}$, quando expostos a doses de $\mathrm{Cu}$. De forma contrária as plantas crescidas com $\mathrm{N}$ na forma de $\mathrm{NO}_{3}{ }^{-}$apresentaram baixíssimos acúmulos de Cu na parte aérea mesmo nas mais altas doses de $\mathrm{Cu}$ em solução nutritiva, pois esse acúmulo nas raízes não ocorreu devido o metal estar sendo transportado para parte aérea. Isso sugere que o suprimento com $\mathrm{N}$ na forma de $\mathrm{NO}_{3}{ }^{-}$age como inibidor do transporte do Cu das raízes para parte aérea, mas não impede que o metal seja absorvido pelas plantas, uma vez que o $\mathrm{Cu}$ foi acumulado nas raízes. Isso também porque as plantas de capim tanzânia recebendo a proporção $70 / 30$ de $\mathrm{NO}_{3}{ }^{-} / \mathrm{NH}_{4}{ }^{+}$apresentaram sintomas visuais de toxidez nas primeiras 24 horas de exposição ao $\mathrm{Cu}$, o que sugere que a absorção e transporte de $\mathrm{Cu}$ foi intensa logo nas primeiras horas de exposição, principalmente na dose de $\mathrm{Cu}$ de $1000 \mu \mathrm{mol} \mathrm{L}{ }^{-1}$. O incremento no acúmulo de $\mathrm{Cu}$ nas raízes das plantas de capim tanzânia supridos com a proporção de $70 / 30$ de $\mathrm{NO}_{3}{ }^{-} / \mathrm{NH}_{4}{ }^{+}$somente ocorreu na dose de $\mathrm{Cu}$ de $1000 \mu \mathrm{mol} \mathrm{\textrm {L } ^ { - 1 }}$ porque essa dose foi suficientemente alta e sugere que o acúmulo desse metal na parte aérea tenha atingido o limite máximo tolerado pela parte aérea da espécie, induzido o acúmulo de $\mathrm{Cu}$ também nas raízes. Com o emprego de 50\% do $\mathrm{N}$ na forma de $\mathrm{NO}_{3}{ }^{-}$e $50 \%$ de $\mathrm{NH}_{4}{ }^{+}$foi verificado efeito intermediário nesse acúmulo, uma vez que não ocorreu incremento no acúmulo de $\mathrm{Cu}$ nas raízes, mesmo nas mais altas doses de $\mathrm{Cu}$, o que pode ser resultado também da toxidez do $\mathrm{NH}_{4}{ }^{+}$(que impossibilita elevados acúmulos de $\mathrm{Cu}$ na parte aérea e também nas raízes).

Algumas hipóteses podem ser formuladas para explicar o efeito de incremento no acúmulo de $\mathrm{Cu}$ em função da inclusão ou não do $\mathrm{NH}_{4}{ }^{+}$nas proporções de $\mathrm{NO}_{3}{ }^{-} / \mathrm{NH}_{4}{ }^{+}$na solução nutritiva. Acredita-se que as raízes do capim podem ter detectado a alta concentração de $\mathrm{NH}_{4}{ }^{+}$no citoplasma, em função do suprimento desse íon na solução nutritiva e ativado a ação de transportadores de $\mathrm{Cu}$ e/ou de metais pesados a partir da regulação positiva dos genes que codificam para esses transportadores. De forma contrária, o suprimento com $\mathrm{N}$ exclusivo como $\mathrm{NO}_{3}{ }^{-}$ pode ter criado as condições bioquímicas necessárias para que esse íon tenha regulado negativamente a expressão desses transportadores. Estes são conhecidos por serem ativados na presença de minerais no meio, como ocorre com silício ( $\mathrm{Si}$ ), que regula negativamente genes transportadores de $\mathrm{Cu}$ do tipo 1 (COPT1) e de metais pesados (HMA5), responsáveis pelo transporte de Cu das raízes para a parte aérea. Essa regulação negativa de genes induzida pela presença de minerais no meio de cultivo restringiu severamente o transporte de $\mathrm{Cu}$ para a parte aérea de Arabidopsis thaliana, resultando em baixíssimo acúmulo de $\mathrm{Cu}$ na parte aérea das plantas (Li et al., 2008), o que permite inferir que o suprimento de $\mathrm{N}$ na forma exclusiva de $\mathrm{NO}_{3}{ }^{-}$pode regular genes similares nas plantas de capim tanzânia, tal qual ocorre nas plantas-modelo. Também pode-se sugerir que a alta concentração de $\mathrm{NH}_{4}{ }^{+}$(participação de 30 a $50 \%$ da dose de $\mathrm{N}$ ) no meio de cultivo, em presença de média a alta contaminação por Cu (doses acima de $500 \mu \mathrm{mol} \mathrm{L}^{-1}$ ) nesse mesmo meio, pode agir como indutor da regulação positiva desses genes que codificam para transportadores de $\mathrm{Cu}$ e de metais pesados, relacionados ao transporte do $\mathrm{Cu}$ das raízes para a parte aérea das plantas. Outros transportadores de metais pesados do tipo-P ATPases (Heavy Metal ATPases), identificados no xilema de arroz (Oryza sativa), são regulados positivamente pela concentração de $\mathrm{Cu}$ no meio, o que conduz ao 
aumento do transporte desse metal para a parte aérea (Deng et al., 2013), assim como outras famílias de transportadores de Cu COPT1-5, identificados em raízes de Arabidopsis thaliana (Sancenón et al., 2003; Sancenón et al., 2004), também desempenham a função de transportar o $\mathrm{Cu}$ das raízes para a parte aérea e são regulados positivamente pela presença de $\mathrm{Cu}$ no meio de cultivo. No presente estudo, é possível que o $\mathrm{NH}_{4}{ }^{+}$também tenha atuado na regulação desses transportadores de $\mathrm{Cu}$ envolvidos no transporte desse metal via xilema para a parte aérea, uma vez que o $\mathrm{N}$ tem efeito marcante na modulação do metabolismo de plantas e na regulação positiva de transportadores (Li et al., 2010).

Pesquisas de outros autores sugerem a provável influência de transportadores de $\mathrm{NO}_{3}{ }^{-}$do tipo NRT 1.1 na indução na deficiência de ferro (Fe) em plantas de Araibdopsis thaliana, o que pode estar em consonância com o constatado no presente estudo, apesar do metal em foco ser outro. Liu et al. (2015) estudaram alta $\left(25 \mathrm{mmol} \mathrm{L}^{-1}\right)$ e baixa $\left(0,5 \mathrm{mmol} \mathrm{L}^{-1}\right)$ disponibilidade de $\mathrm{NO}_{3}{ }^{-}$em duas linhagens de Arabidopsis thaliana (uma do tipo selvagem e outra mutante-chl1-5, com disrupção na funcionalidade de genes que codificam para o transportador NRT 1.1) e concluíram que, em condição de alta disponibilidade de $\mathrm{NO}_{3}{ }^{-}$, a planta mutante (que apresentou menor expressão relativa de NRT 1.1 e menor atividade da nitrato redutase), foi mais eficiente em absorver Fe, enquanto o tipo selvagem (que apresentou alta expressão relativa de NRT 1.1 e alta atividade da nitrato redutase) foi menos eficientes em absorver esse metal. Esse efeito não ocorreu nas plantas do tipo selvagem de Arabidopsis thaliana supridas exclusivamente com $\mathrm{N}$ na forma de $\mathrm{NO}_{3}{ }^{-}$em baixas concentrações. Isso significa que na fase inicial de crescimento, plantas supridas com alta dose de $\mathrm{N}$ na forma de $\mathrm{NO}_{3}{ }^{-}$apresentam alta atividade de transportadores de $\mathrm{NO}_{3}{ }^{-}$e alta atividade da nitrato redutase, o que está relacionada com a capacidade das plantas em absorver Fe em quantidades satisfatórias ao adequado crescimento. Entende-se ser possível que esse efeito também ocorra para o capim tanzânia, haja visto que esse capim quando suprido com $100 \%$ do $\mathrm{N}$ na forma de $\mathrm{NO}_{3}{ }^{-}$apresentou alta atividade da nitrato redutase e significativa modificação no padrão de acúmulo de $\mathrm{NO}_{3}{ }^{-}$, sugerindo alta atividade de transportadores de $\mathrm{NO}_{3}-$ e concordando com o constatado por Liu et al. (2015).

A toxidez por $\mathrm{Cu}$ nas plantas conduz à síntese excessiva de espécies reativas de oxigênio (ERO), que causam estresse oxidativo e peroxidação lipídica nas plantas, quando expostas a elevadas concentrações de $\mathrm{Cu}$ no meio de cultivo (Gilabel et al., 2014; Thounaojam et al., 2012). O presente trabalho ratifica tal efeito no capim tanzânia, mas sem influência direta na síntese de $\mathrm{H}_{2} \mathrm{O}_{2}$ no capim. É possível que o $\mathrm{Cu}$ esteja influenciando espécies reativas de oxigênio como o ânion superóxido $\mathrm{O}_{2}{ }^{-}$e outras ERO que também causam peroxidação lipídica, o que foi mostrado pelo incremento na concentração de malondialdeído (MDA) nas partes da planta (Tewari et al., 2006). As proporções de $\mathrm{NO}_{3}{ }^{-} / \mathrm{NH}_{4}{ }^{+}$não influenciaram na concentração de MDA nas partes da planta, particularmente nas raízes, órgão que mostrou ser chave do processo que envolve a toxidez por $\mathrm{Cu}$ no capim tanzânia em função de proporções de $\mathrm{NO}_{3}{ }^{-} / \mathrm{NH}_{4}{ }^{+}$. Isso pode ser decorrência do excesso de $\mathrm{Cu}$ na solução nutritiva estar em contato direto com as raízes, independente se a planta foi crescida em variações de proporções de $\mathrm{NO}_{3}{ }^{-} / \mathrm{NH}_{4}{ }^{+}$, o que causou peroxidação lipídica no sistema radicular como um todo e também refletiu na parte aérea. Isso está de acordo com o fato das plantas desse capim apresentarem maior acúmulo de Cu nas raízes, especialmente nas proporções 100/0 e 70/30 de $\mathrm{NO}_{3}{ }^{-} / \mathrm{NH}_{4}{ }^{+}$, o que justifica a influência do $\mathrm{Cu}$ na peroxidação lipídica do capim nesse órgão.

De forma significativa, o aumento da participação do $\mathrm{NH}_{4}{ }^{+}$na proporção de $\mathrm{NO}_{3}{ }^{-} / \mathrm{NH}_{4}{ }^{+}$também induziu a síntese de ERO e principalmente $\mathrm{H}_{2} \mathrm{O}_{2}$, o que conduziu ao aumento da peroxidação lipídica, indicada pelo aumento da concentração de MDA nas LR do capim tanzânia. Esses resultados mostram que o suprimento com alta participação de $\mathrm{NH}_{4}{ }^{+}$na dose de $\mathrm{N}$ também é tóxico às células, mesmo que a inclusão do $\mathrm{NH}_{4}{ }^{+}$até $50 \%$ da dose de $\mathrm{N}$ na solução nutritiva tenha proporcionado maior crescimento e produção do capim aruana (Santos et al., 2013) e 
em especial no capim tanzânia que apresentou maior produção de massa seca quando suprido com proporção de 70/30 de $\mathrm{NO}_{3}{ }^{-} / \mathrm{NH}_{4}{ }^{+}$em condição de $\mathrm{Cu}$ adequado ao seu crescimento. Sabe-se que o suprimento com elevada participação de $\mathrm{NH}_{4}{ }^{+}$de até $50 \%$ na dose de $\mathrm{N}$ causa estresse oxidativo e peroxidação lipídica, que podem interferir negativamente na respiração das raízes, no balanço osmótico das células, na disrupção da homeostase hormonal e no aumento da fotorrespiração das plantas, nas espécies vegetais sensíveis ao excesso de $\mathrm{NH}_{4}{ }^{+}$(Esteban et al., 2016). Nas espécies vegetais tolerantes ao excesso de $\mathrm{NH}_{4}{ }^{+}$, apesar do suprimento com esse íon resultar em estresse oxidativo, hipóteses recentes sugerem que elevadas concentrações de $\mathrm{NH}_{4}^{+}$no meio de cultivo, além de influenciarem na síntese de aminoácidos como o glutamato e prolina, promovem a adequada regulação das aquaporinas e da auxina, podendo ainda regular positivamente genes que codificam para guanosina difosfato manose (GDP-manose), esta última diretamente envolvida na síntese do ácido ascórbico e na síntese e integridade da parede celular (Esteban et al., 2016). Essas constatações permitem destacar que o capim tanzânia é planta tolerante até 30\% do $\mathrm{N}$ na forma de $\mathrm{NH}_{4}{ }^{+}$em solução nutritiva.

A síntese excessiva de ERO induzida pela toxidez de $\mathrm{Cu}$ foi indicada principalmente pelas altas concentrações de MDA nas partes da planta em situação de alta contaminação do meio de cultivo por Cu. Sabe-se que o principal efeito negativo da toxidez por esse metal está relacionado aos danos oxidativos nos cloroplastos das plantas, uma vez que as ERO causam peroxidação lipídica nas membranas dos tilacoides, que alteram a capacidade das plantas em absorver fótons e transportar os elétrons pela cadeia transportadora de elétrons no fotossistema II. Como consequência, os elétrons altamente reativos captados pelos pigmentos-antena ou pelo próprio centro de reação do fotossistema II são desviados da cadeia transportadora e intensificam a peroxidação lipídica nas membranas dos tilacoides (Bazihizina et al., 2015). Como consequência, a toxidez de Cu afeta negativamente o complexo de evolução do oxigênio (Pätsikkä et al., 2002) e, em conjunto aos demais efeitos negativos, resultem em menores eficiência quântica do fotossistema II, taxa de transporte de elétrons, taxa de transpiração, condutância estomática e taxa de assimilação de $\mathrm{CO}_{2}$ (Thounaojam et al., 2012). Esses efeitos também foram constatados no capim tanzânia, submetido a elevadas doses de $\mathrm{Cu}$, o que ratifica ser um dos principais efeitos tóxicos do $\mathrm{Cu}$ a drástica diminuição da taxa fotossintética. Cabe destacar que a toxidez de $\mathrm{Cu}$ afeta negativamente uma de suas principais funções nas plantas, que é de promover adequada fotossíntese.

A condutância estomática do capim tanzânia foi o único atributo fotossintético que mostrou efeitos de alívio de estresse induzidos pelas formas iônicas de $\mathrm{N}$, mas apenas nas plantas supridas com $\mathrm{N}$ na forma de $\mathrm{NO}_{3}{ }^{-}$ combinada às doses de $\mathrm{Cu}$ de 250 e $500 \mu \mathrm{mol} \mathrm{L}-1$. Isso ocorreu porque o suprimento do $\mathrm{N}$ exclusivamente na forma de $\mathrm{NO}_{3}{ }^{-}$minimizou o transporte do excesso de $\mathrm{Cu}$ das raízes para a parte aérea, o que aliviou o efeito tóxico do $\mathrm{Cu}$ no aparato fotossintético do capim tanzânia. Entretanto, isso não ocorreu no capim exposto ao Cu de $1000 \mu \mathrm{mol} \mathrm{L}{ }^{-1}$, pois essa dose foi excessivamente tóxica, acabando por afetar também as plantas cultivadas com $\mathrm{N}$ na forma de $\mathrm{NO}_{3}{ }^{-}$. Isso porque na proporção $100 / 0$ de $\mathrm{NO}_{3}{ }^{-} / \mathrm{NH}_{4}{ }^{+}$as raízes apresentaram elevado acúmulo de $\mathrm{Cu}$ e isso também pode ter contribuído para a baixa condutância estomática do capim. Sabe-se que um dos efeitos negativos do estresse oxidativo por toxidez de $\mathrm{Cu}$ é a diminuição da condutância estomática, o que afeta negativamente a absorção e o transporte de água das raízes para a parte aérea do capim e altera o balanço hídrico e a turgidez das plantas (Costa e Sharma, 2016). Esse efeito explica porque as plantas de capim tanzânia mais afetadas pela toxidez de $\mathrm{Cu}$ apresentarem como sintoma visual de toxidez o murchamento das folhas, especialmente nas plantas supridas com $\mathrm{NO}_{3}{ }^{-}$e $\mathrm{NH}_{4}{ }^{+}$. Bazihizina et al. (2015) cultivaram plantas de Silene paradoxa em solução nutritiva com doses de Cu de até $40 \mu \mathrm{mol} \mathrm{L}{ }^{-1}$ e constataram que taxa de assimilação, eficiência quântica do fotossistema II e taxa de transporte de elétrons foram menores do que nas plantas supridas com dose de $\mathrm{Cu}$ ao crescimento, ao mesmo tempo em que 
associaram os resultados ao efeito negativo da elevada peroxidação lipídica nos cloroplastos das plantas, medida na forma de MDA. Apesar disso, no segundo crescimento do capim, quando não ocorreu a exposição ao Cu, verificouse padrão oposto para eficiência quântica do fotossistema II e taxa de transporte de elétrons, as quais foram maiores nas mais altas doses de $\mathrm{Cu}$. De forma similar ao ocorrido com a atividade da nitrato redutase, este efeito também pode ser associado à tentativa da planta em aliviar o estresse decorrente da exposição ao Cu no primeiro crescimento, para garantir condições de rebrotação adequadas à persistência do capim no meio de cultivo.

O aminoácido prolina tem sido reconhecido como antioxidante não enzimático de relevância na tolerância de plantas ao estresse oxidativo causado por $\mathrm{Cu}$, uma vez que em condição de toxidez por Cu as plantas incrementam a síntese desse aminoácido na tentativa de aliviar o estresse oxidativo (Chen et al., 2001; Singh et al., 2010; Hayat et al., 2012; Al Khateeb e Al-Qwasemeh, 2014). No entanto, não há publicações mostrando a influência das formas iônicas de $\mathrm{N}$ fornecidas no meio de cultivo no incremento da síntese desse aminoácido, especialmente nas gramíneas tropicais. Nesse sentido, a presente pesquisa contribui no sentido de mostrar que a síntese desse aminoácido ocorreu em elevada escala nas plantas supridas com $\mathrm{NO}_{3}{ }^{-}$e $\mathrm{NH}_{4}{ }^{+}$em situação de estresse por excesso de $\mathrm{Cu}$, o que não ocorreu nas plantas supridas exclusivamente com $\mathrm{N}$ na forma de $\mathrm{NO}_{3}{ }^{-}$. Esses resultados estiveram diretamente relacionados à maior concentração de $\mathrm{NH}_{4}{ }^{+}$na parte aérea das plantas, assim como à atividade da glutamina sintetase, significando que, em situação de estresse por excesso de $\mathrm{Cu}$, o suprimento com $\mathrm{N}$ parcialmente na forma de $\mathrm{NH}_{4}{ }^{+}$favorece alta concentração desse íon na parte aérea e alta atividade da glutamina sintetase.

A prolina é aminoácido derivado do glutamato, primeiro aminoácido formado a partir da assimilação do $\mathrm{NH}_{4}{ }^{+}$(Singh et al., 2010), o que explica as altíssimas concentrações de prolina nas LR e DC da parte aérea do capim. Dessa forma, é possível que a planta ao detectar o estresse oxidativo causado pela toxidez de Cu na parte aérea induza o transporte do $\mathrm{NH}_{4}{ }^{+}$fornecido em solução nutritiva, das raízes para a parte aérea, proporcionando a elevada concentração de $\mathrm{NH}_{4}{ }^{+}$na parte aérea e consequentemente alta atividade da glutamina sintetase, no sentido de assimilar $\mathrm{NH}_{4}^{+}$e sintetizar a maior quantidade de prolina, visando tolerar o estresse oxidativo causado por Cu na parte aérea. Esse efeito não ocorreu nas raízes, sugerindo ser esse antioxidante não enzimático sintetizado em maior escala pelas folhas do capim e o responsável pelo alívio da toxidez de $\mathrm{Cu}$ na parte aérea. A prolina, em elevada concentração no citoplasma, atua como potente osmorregulador, garantindo a estabilidade das estruturas subcelulares (como as membranas e proteínas) em situação de alto estresse por toxidez de $\mathrm{Cu}$, além de eliminarem diretamente as ERO a partir de reações redox e aliviando a acidose excessiva provocada pelo excesso de Cu no citoplasma (Hayat et al., 2012). Outra importante ação da prolina é a capacidade desse aminoácido em proporcionar a relação adequada entre NADP/NADPH, de forma a garantir a síntese desses metabólitos que contribuem para manutenção da homeostase celular (Hayat et al., 2012) e garantem a adequada atividade de enzimas dependentes de poder redutor. Anteriormente foi verificado que a toxidez de $\mathrm{Cu}$ de $1000 \mu \mathrm{mol} \mathrm{L}{ }^{-1}$ induziu a síntese de prolina na parte aérea do capim tanzânia, mas a síntese foi menor quando as plantas foram supridas com alta dose de S (4 mmol $\left.\mathrm{L}^{-1}\right)$, sugerindo ser o S elemento importante na síntese de compostos e na atividade de enzimas que são dependentes desse elemento (Gilabel et al., 2014), como a glutationa reduzida (GSH) sintetizada a partir da glutationa redutase. Entretanto, no presente trabalho o suprimento com parte da dose de $\mathrm{N}$ na forma de $\mathrm{NH}_{4}{ }^{+}$em solução nutritiva mostrou ser de fundamental relevância para a síntese da prolina, que por sua vez apresentou alta concentração na situação do capim sob estresse por $\mathrm{Cu}$.

Influenciada pelo suprimento com $\mathrm{N}$ nas formas de $\mathrm{NO}_{3}{ }^{-}$e $\mathrm{NH}_{4}{ }^{+}$, a prolina mostrou ser aminoácido antioxidante de fundamental importância para o capim tolere altos níveis de $\mathrm{Cu}$ em sua parte aérea. No entanto, nas raízes esse efeito não foi constatado porque nesse órgão o principal sistema antioxidante que assumiu papel de alívio 
de estresse foi a defesa antioxidante enzimática, principalmente na ação da enzima SOD, que também apresentou papel relevante na desintoxicação de ERO na parte aérea. No primeiro e segundo crescimento do capim tanzânia, a atividade da SOD nas LR detectadas por eletroforese não apresentou claro sinal de incremento de atividade, em consequência do emprego das proporções de $\mathrm{NO}_{3}-/ \mathrm{NH}_{4}{ }^{+}$. No entanto, na parte aérea foi possível notar nitidamente que a ação da SOD ocorreu, sobretudo, nos DC da parte aérea do capim, principalmente nas plantas supridas com proporção de $70 / 30$ de $\mathrm{NO}_{3}{ }^{-} / \mathrm{NH}_{4}{ }^{+}$e expostas à dose de $\mathrm{Cu}$ de $1000 \mu \mathrm{mol} \mathrm{L}{ }^{-1}$ no primeiro crescimento ou Cu de $500 \mu \mathrm{mol} \mathrm{L}{ }^{-1}$ no segundo crescimento, em atividade decorrente do alto acúmulo de Cu propiciado pela combinação de $\mathrm{NO}_{3}{ }^{-}$ao $\mathrm{NH}_{4}{ }^{+}$. Dessa forma, a inclusão do $\mathrm{NH}_{4}{ }^{+}$na solução nutritiva resultou em maior produção de energia metabólica, a qual foi canalizada também para induzir alta atividade da SOD na tentativa de aliviar o estresse ocasionado pela síntese excessiva de ERO.

Apesar do claro incremento na atividade da SOD no tecido coletado ao final do primeiro crescimento do capim, quando houve exposição às doses altas de $\mathrm{Cu}$, o efeito mais pronunciado da atividade dessa enzima foi detectado no sistema radicular do capim. O sistema radicular do capim tanzânia mostrou ser chave no que se refere ao potencial fitorremediador dessa espécie, em função do fornecimento de proporções de $\mathrm{NO}_{3}{ }^{-} / \mathrm{NH}_{4}{ }^{+}$, pois é o sistema radicular do capim tanzânia que parece controlar o transporte ou não do excesso de Cu para a parte aérea, o qual modula o potencial fitoextrator do capim tanzânia. A atividade da SOD nas raízes do capim tanzânia foi altamente incrementada nas plantas supridas com $\mathrm{N}$ combinando $\mathrm{NO}_{3}{ }^{-}$ao $\mathrm{NH}_{4}{ }^{+}$. Isso porque as plantas supridas com $\mathrm{NO}_{3}{ }^{-}$e $\mathrm{NH}_{4}{ }^{+}$apresentaram elevado acúmulo de $\mathrm{Cu}$ e consequentemente altos níveis de toxidez desse metal. Esse efeito também ocorreu em menor escala nas plantas supridas com $\mathrm{N}$ exclusivo na forma de $\mathrm{NO}_{3}^{-}$, pois quando expostas a elevadas doses de $\mathrm{Cu}$ na solução nutritiva não houve impedimento no acúmulo de grandes quantidades desse metal nas raízes, acúmulo esse que conduziu a síntese excessiva de ERO nesse órgão e consequente incremento na atividade da SOD no capim tanzânia.

A síntese excessiva do ânion superóxido $\left(\mathrm{O}_{2}^{-}\right)$nas células das plantas é a primeira ERO formada pela indução por altas concentrações de $\mathrm{Cu}$ no meio de cultivo, sendo altamente prejudicial às espécies vegetais. Como resposta de defesa, plantas desenvolveram enzimas capazes de converter esse radical para formas menos tóxicas como o $\mathrm{H}_{2} \mathrm{O}_{2}$, a partir do potencial redox de enzimas, via reação Fenton e Haber-Weiss (Liu et al., 2015). Nesse contexto, as enzimas antioxidantes agem mantendo a homeostase celular em condição de toxidez por Cu e a primeira enzima a agir contra o ânion superóxido nessa condição de toxidez é a SOD, que catalisa a dismutação do $\mathrm{O}_{2}^{-}$em $\mathrm{H}_{2} \mathrm{O}_{2}$ e oxigênio molecular $\left(\mathrm{O}_{2}\right)$. Três isoformas de SOD foram identificadas em plantas com base no metal co-fator, sendo ferro-SOD (FeSOD), manganês-SOD (MnSOD) e cobre/zinco-SOD (Cu/ZnSOD), apontadas como agentes de desintoxicação de $\mathrm{O}_{2}^{-}$(Myouga et al., 2008). Isso explica o fato das isoformas de SOD apresentarem maior atividade nas plantas supridas com $\mathrm{N}$ combinando $\mathrm{NO}_{3}{ }^{-}$ao $\mathrm{NH}_{4}{ }^{+}$e expostas a elevadas doses de $\mathrm{Cu}$, uma vez que as plantas nessas condições puderam acumular elevadas quantidades de $\mathrm{Cu}$, que consequentemente ativaram os mecanismos de defesa oxidativa necessária à desintoxicação das ERO, induzidas pelos elevados acúmulos do metal na biomassa.

Independente das proporções de $\mathrm{NO}_{3}{ }^{-} / \mathrm{NH}_{4}{ }^{+}$às quais as plantas foram submetidas, houve incremento das atividades das enzimas CAT, GPX, APX e GR com o aumento das doses de Cu, como estratégias de defesa contra ERO no sistema radicular do capim. Isso sugere que o sistema radicular do capim, apesar de fortemente afetado pela toxidez de $\mathrm{Cu}$, possui mecanismos eficientes de desintoxicação para garantir a sobrevivência da planta em meio contaminado. Entende-se que o fato das proporções de $\mathrm{NO}_{3}{ }^{-} / \mathrm{NH}_{4}{ }^{+}$não afetarem as atividade das enzimas no sistema radicular foi sinal de que a atividade da SOD, induzida principalmente pelo suprimento combinando 
$\mathrm{NO}_{3}{ }^{-}$ao $\mathrm{NH}_{4}{ }^{+}$, foi suficiente para garantir que as peroxidases das plantas atuassem independente das proporções de $\mathrm{NO}_{3}{ }^{-} / \mathrm{NH}_{4}{ }^{+}$. As isoenzimas do grupo das peroxidases, som similar importância em relação à SOD, agem convertendo o $\mathrm{H}_{2} \mathrm{O}_{2}$ (que ainda é tóxico as células devido seu potencial de causar peroxidação lipídica) formado pela $\mathrm{SOD}$ em $\mathrm{H}_{2} \mathrm{O}$ e $\mathrm{O}_{2}$, ou seja, formas não tóxicas as plantas. Nesse contexto, destacam-se as atuações das enzimas CAT e GPX no sistema radicular, esta última utilizando como substrato o guaiacol (Carrasco-Gil et al., 2012; Fidalgo et al., 2013), as quais agiram eliminando os radicais peróxidos das células do capim, o que pode ter influenciado na não significância da produção de $\mathrm{H}_{2} \mathrm{O}_{2}$ em função das doses de $\mathrm{Cu}$.

Outro mecanismo eficiente de garantia da homeostase celular e desintoxicação de ERO foi a manutenção do ciclo ascorbato-glutationa. Nesse ciclo, a enzima APX catalisa reação-chave na qual o substrato ascorbato é oxidado e o $\mathrm{H}_{2} \mathrm{O}_{2}$ é reduzido a $\mathrm{H}_{2} \mathrm{O}$. Nesse contexto, a regeneração do ascorbato é dependente também da regeneração da GSH, que ao ser oxidada pela glutationa oxidase necessita ser novamente reduzida a partir da catálise da enzima GR, o que explicita a maior atividade dessa enzima na dose mais alta de Cu. Além disso, tem sido mostrado que o metabólito GSH (sintetizado pela enzima GR), também pode agir diretamente como agente redox e/ou quelante de metais tóxicos livres no citoplasma, compartimentalizando-os no vacúolo e diminuindo a reatividade do metal no citoplasma e outros compartimentos sub-celulares (Drazkiewicz et al., 2003; Paulose et al., 2013). Nesse contexto, destaca-se a importância fundamental da elevada síntese de prolina nas plantas estressadas, para garantir adequada relação NADP/NADPH (Hayat et al., 2012) e adequada atuação de enzimas dependentes de poder redutor, como a enzima GR, que é dependente de NADPH como poder redutor para reduzir a glutationa oxidada em GSH. Quando plantas de feijão (Phaseolus vulgaris) foram cultivadas em solução nutritiva contendo Cu de $15 \mu \mathrm{mol} \mathrm{L}{ }^{-1}$, a peroxidação lipídica foi maior e, consequentemente, a fitotoxidez do metal. Ocorreu ainda resposta do sistema de defesa antioxidante da planta, indicada pelas maiores atividades das enzimas APX e GR em condição de toxidez de $\mathrm{Cu}$, comparado à condição com ausência de toxidez (Pätsikkä et al., 2002). Isso mostra que mesmo plantas de outras espécies também apresentam sistema de defesa funcional contra a toxidez de Cu e sugere que a coevolução das plantas com os metais ocorreu nas espécies vegetais como um todo, apesar de que o capim tanzânia se mostrou mais tolerante do que diversas plantas de relevância econômica e até mesmo de plantas de conhecido potencial fitorremediador, uma vez que foi capaz de tolerar concentrações de Cu em solução nutritiva 50 vezes maior que plantas de tabaco (Nicotiana tabacum) expostas ao $\mathrm{Cu}$ de $20 \mu \mathrm{mol} \mathrm{L} \mathrm{L}^{-1}$, transformadas para expressarem os genes Elsholtria haichowensis metallothionein 1 (EhMT1), apontados como chave para a tolerância de plantas de Elsholtria haichowensis, descritas como hiperacumuladoras de $\mathrm{Cu}$ (Xia et al., 2012).

\subsection{Conclusão}

A tolerância do capim tanzânia ao estresse por toxidez de $\mathrm{Cu}$, e consequentemente o acúmulo de $\mathrm{Cu}$ e a persistência da planta no meio de cultivo contaminado, dependem da concentração desse metal no meio de cultivo, assim como das proporções de formas iônicas de $\mathrm{N}$ nas quais as plantas foram crescidas. $\mathrm{O}$ excesso de Cu afeta drasticamente a atividade fotossintética do capim, que induz a síntese de prolina e a atividade da superóxido dismutase, que se mostraram de relevante importância na parte aérea do capim. Apesar do sistema radicular do capim ser fortemente afetado pela toxidez de $\mathrm{Cu}$, o capim apresentou eficiente sistema de defesa antioxidante, mediado principalmente pela ação da enzima superóxido dismutase, assim como da catalase, guaiacol peroxidase, ascorbato peroxidase e glutationa redutase, que manteve ativa a ascorbato peroxidase, além de possivelmente atuar diretamente na defesa oxidativa a partir da síntese de glutationa reduzida. Conclui-se que o capim tanzânia é tolerante ao excesso 
de $\mathrm{Cu}$ e que a inclusão do $\mathrm{NH}_{4}{ }^{+}$como fonte de $\mathrm{N}$ no meio de cultivo induz o aumento do acúmulo de Cu na parte aérea e o incremento da tolerância das plantas ao estresse oxidativo causado pelo excesso desse metal.

\section{Referências}

Al Khateeb, W., Al-Qwasemeh, H., 2014. Cadmium, copper and zinc toxicity effects on growth, proline content and genetic stability of Solanum nigrum L., a crop wild relative for tomato; comparative study. Physiol. Mol. Biol. Plants 20, 31-39. doi:10.1007/s12298-013-0211-5

Azevedo, R.A., Alas, R.M., Smith, R.J., Lea, P.J., 1998. Response of antioxidant enzymes to transfer from elevated carbon dioxide to air and ozone fumigation, in the leaves and roots of wild-type and a catalase-deficient mutant of barley. Physiol. Plant. 104, 280-292. doi:10.1034/j.1399-3054.1998.1040217.x

Bates, L.S., Waldren, R.P., Teare, I.D., 1973. Rapid determination of free proline for water-stress studies. Plant Soil 39, 205-207. doi:10.1007/BF00018060

Bazihizina, N., Colzi, I., Giorni, E., Mancuso, S., Gonnelli, C., 2015. Photosynthesizing on metal excess: Copper differently induced changes in various photosynthetic parameters in copper tolerant and sensitive Silene paradoxa L. populations. Plant Sci. 232, 67-76. doi:10.1016/j.plantsci.2014.12.015

Bradford, M.M., 1976. A rapid and sensitive method for the quantitation of microgram quantities of protein utilizing the principle of protein-dye binding. Anal. Biochem. 72, 248-254. doi:10.1016/0003-2697(76)90527-3

Cakmak, I., Horst, W.J., 1991. Effect of aluminium on lipid peroxidation, superoxide dismutase, catalase, and peroxidase activities in root tips of soybean (Glycine max). Physiol. Plant. 83, 463-468. doi:10.1111/j.13993054.1991.tb00121.x

Carrasco-Gil, S., Estebaranz-Yubero, M., Medel-Cuesta, D., Millán, R., Hernández, L.E., 2012. Influence of nitrate fertilization on $\mathrm{Hg}$ uptake and oxidative stress parameters in alfalfa plants cultivated in a Hg-polluted soil. Environ. Exp. Bot. 75, 16-24. doi:10.1016/j.envexpbot.2011.08.013

Cassella, R.J., Wagener, A. d L.R., Santelli, R.E., Wagener, K., Tavares, L.Y., 2007. Distribution of copper in the vicinity of a deactivated mining site at Carajás in the Amazon region of Brazil. J. Hazard. Mater. 142, 543-549. doi:10.1016/j.jhazmat.2006.08.060

Chen, C.T., Chen, L.M., Lin, C.C., Kao, C.H., 2001. Regulation of proline accumulation in detached rice leaves exposed to excess copper. Plant Sci. 160, 283-290. doi:10.1016/S0168-9452(00)00393-9

Cohu, C.M., Pilon, M., 2007. Regulation of superoxide dismutase expression by copper availability. Physiol. Plant. 129, 747-755. doi:10.1111/j.1399-3054.2007.00879.x

Costa, M.V.J., Sharma, P.K., 2016. Effect of copper oxide nanoparticles on growth, morphology, photosynthesis, and antioxidant response in Oryza sativa. Photosynthetica. 54, 110-119. doi:10.1007/s11099-015-0167-5

Deng, F., Yamaji, N., Xia, J., Ma, J.F., 2013. A member of the heavy metal P-type ATPase OsHMA5 is involved in xylem loading of copper in rice. Plant Physiol. 163, 1353-62. doi:10.1104/pp.113.226225

Drazkiewicz, M., Skórzynska-Polit, E., Krupa, Z., 2003. Response of the ascorbate-glutathione cycle to excess copper in Arabidopsis thaliana (L.). Plant Sci. 164, 195-202.

Epstein, E., Bloom, A.J., 2006. Nutrição mineral de plantas. 3 ed., Editora Planta: Londrina, 403 p.

Esteban, R., Ariz, I., Cruz, C., Moran, J.F., 2016. Review: Mechanisms of ammonium toxicity and the quest for tolerance. Plant Sci. 248, 92-101. doi:10.1016/j.plantsci.2016.04.008 
Fernández-Calviño, D., Soler-Rovira, P., Polo, A., Díaz-Raviña, M., Arias-Estévez, M., Plaza, C., 2010. Enzyme activities in vineyard soils long-term treated with copper-based fungicides. Soil Biol. Biochem. 42, 2119-2127. doi:10.1016/j.soilbio.2010.08.007

Fidalgo, F., Azenha, M., Silva, A.F., Sousa, A., Santiago, A., Ferraz, P., Teixeira, J., 2013. Copper-induced stress in Solanum nigrum L. and antioxidant defense system responses. Food Energy Secur. 2, 70-80. doi:10.1002/fes3.20

Gilabel, A.P., Nogueirol, R.C., Garbo, A.I., Monteiro, F.A., 2014. The role of sulfur in increasing guinea grass tolerance of copper phytotoxicity. Water. Air. Soil Pollut. 225, 1806-1816. doi:10.1007/s11270-013-1806-8

Gratão, P.L., Monteiro, C.C., Antunes, A.M., Peres, L.E.P., Azevedo, R.A., 2008. Acquired tolerance of tomato (Lycopersicon esculentum cv. Micro-Tom) plants to cadmium-induced stress. Ann. Appl. Biol. 153, 321-333. doi:10.1111/j.1744-7348.2008.00299.x

Hamlin, R.L., Barker, A. V, 2006. Influence of ammonium and nitrate nutrition on plant growth and zinc accumulation by indian mustard. J. Plant Nutr. 29, 1523-1541. doi:10.1080/01904160600837709

Hayat, S., Hayat, Q., Alyemeni, M.N., Wani, A.S., Pichtel, J., Ahmad, A., 2012. Role of proline under changing environments: a review. Plant Signal. Behav. 7, 1456-66. doi:10.4161/psb.21949

Heath, R.L., Packer, L., 1968. Photoperoxidation in isolated chloroplasts: I. Kinetics and Stoichiometry of fatty acid peroxidation. Arch. Biochem. Biophys. 125, 189-198. doi:10.1016/0003-9861(68)90654-1

Heldt, H.W., 2005. Plant biochemistry. 3 ed. Elsevier: Amsterdam, 630 p.

Hoagland, D.R., Arnon, D.I., 1950. The water culture method for growing plants without soils. Berkeley: California Agricultural Experimental Station, 347 p.

Keunen, E., Remans, T., Bohler, S., Vangronsveld, J., Cuypers, A., 2011. Metal-induced oxidative stress and plant mitochondria. Int. J. Mol. Sci. 12, 6894-6918. doi:10.3390/ijms12106894

Kováčik, J., Hedbavny, J., 2014. Ammonium ions affect metal toxicity in chamomile plants. South African J. Bot. 94, 204-209. doi:10.1016/j.sajb.2014.06.016

Li, J., Leisner, S.M., Frantz, J., 2008. Alleviation of copper toxicity in Arabidopsis thaliana by silicon addition to hydroponic solutions. J. Am. Soc. Hortic. Sci. 133, 670-677.

Li, J.-Y., Fu, Y.-L., Pike, S.M., Bao, J., Tian, W., Zhang, Y., Chen, C.-Z., Zhang, Y., Li, H.-M., Huang, J., Li, L.-G., Schroeder, J.I., Gassmann, W., Gong, J.-M., 2010. The Arabidopsis nitrate transporter NRT1.8 functions in nitrate removal from the xylem sap and mediates cadmium tolerance. Plant Cell 22, 1633-1646. doi:10.1105/tpc.110.075242

Liu, J., Shi, X., Qian, M., Zheng, L., Lian, C., Xia, Y., Shen, Z., 2015. Copper-induced hydrogen peroxide upregulation of a metallothionein gene, OsMT2c, from Oryza sativa L. confers copper tolerance in Arabidopsis thaliana. J. Hazard. Mater. 294, 99-108. doi:10.1016/j.jhazmat.2015.03.060

Liu, X., Cui, H., Li, A., Zhang, M., Teng, Y., 2015. The nitrate transporter NRT1.1 is involved in iron deficiency responses in Arabidopsis. J. Plant Nutr. Soil Sci. 178, 601-608. doi:10.1002/jpln.201400480

Madejón, P., Ramírez-Benítez, J.E., Corrales, I., Barceló, J., Poschenrieder, C., 2009. Copper-induced oxidative damage and enhanced antioxidant defenses in the root apex of maize cultivars differing in $\mathrm{Cu}$ tolerance. Environ. Exp. Bot. 67, 415-420. doi:10.1016/j.envexpbot.2009.08.006

Mahanty, S., Kaul, T., Pandey, P., Reddy, R.A., Mallikarjuna, G., Reddy, C.S., Sopory, S.K., Reddy, M.K., 2012. Biochemical and molecular analyses of copper-zinc superoxide dismutase from a C4 plant Pennisetum glaucum reveals an adaptive role in response to oxidative stress. Gene. 505, 309-317. doi:10.1016/j.gene.2012.06.001 
Matsuno, H., Uritani, I., 1972. Physiological behavior of peroxidase isozymes in sweet potato root tissue injured by cutting or with black rot. Plant Cell Physiol, v. 13, p. 1091-1101.

Monteiro, C.C., Carvalho, R.F., Gratão, P.L., Carvalho, G., Tezotto, T., Medici, L.O., Peres, L.E.P., Azevedo, R.A., 2011a. Biochemical responses of the ethylene-insensitive Never ripe tomato mutant subjected to cadmium and sodium stresses. Environ. Exp. Bot. 71, 306-320. doi:10.1016/j.envexpbot.2010.12.020

Monteiro, F.A., Nogueirol, R.C., Melo, L.C.A., Artur, A.G., da Rocha, F., 2011b. Effect of barium on growth and macronutrient nutrition in tanzania guineagrass grown in nutrient solution. Commun. Soil Sci. Plant Anal. 42, 1510-1521. doi:10.1080/00103624.2011.581725

Myouga, F., Hosoda, C., Umezawa, T., Iizumi, H., Kuromori, T., Motohashi, R., Shono, Y., Nagata, N., Ikeuchi, M., Shinozaki, K., 2008. A heterocomplex of iron superoxide dismutases defends chloroplast nucleoids against oxidative stress and is essential for chloroplast development in Arabidopsis. Plant Cell 20, 3148-3162. doi:10.1105/tpc.108.061341

Nogueirol, R.C., Alleoni, L.R.F., Nachtigall, G.R., de Melo, G.W., 2010. Sequential extraction and availability of copper in $\mathrm{Cu}$ fungicide-amended vineyard soils from Southern Brazil. J. Hazard. Mater. 181, 931-937. doi:10.1016/j.jhazmat.2010.05.102

Nogueirol, R.C., de Melo, W.J., Bertoncini, E.I., Alleoni, L.R.F., 2013. Concentrations of Cu, Fe, Mn, and Zn in tropical soils amended with sewage sludge and composted sewage sludge. Environ. Monit. Assess. 185, 2929_2938. doi:10.1007/s10661-012-2761-3

Pätsikkä, E., Kairavuo, M., Sersen, F., Aro, E.-M., Tsystjärvi, E., 2002. Excess copper predisposes photosystem II to photoinhibition in vivo by outcompeting iron and causing decrease in leaf chlorophyll. J. Plant Physiol. 129, 1359-1367. doi:10.1104/pp.004788.1

Paulose, B., Chhikara, S., Coomey, J., Jung, H. Il, Vatamaniuk, O., Dhankher, O.P., 2013. A $\gamma$-glutamyl cyclotransferase protects arabidopsis plants from heavy metal toxicity by recycling glutamate to maintain glutathione homeostasis. Plant Cell. 25, 4580-4595. doi:10.1105/tpc.113.111815

Rabêlo, F.H.S., Azevedo, R.A., Monteiro, F.A., 2016. Proper supply of S increases GSH synthesis in the establishment and reduces tiller mortality during the regrowth of Tanzania guinea grass used for Cd phytoextraction. J. Soils Sediments. 1, 1-10. doi:10.1007/s11368-016-1429-y

Sancenón, V., Puig, S., Mateu-Andrés, I., Dorcey, E., Thiele, D.J., Peñarrubia, L., 2004. The Arabidopsis copper transporter COPT1 functions in root elongation and pollen development. J. Biol. Chem. 279, 15348-15355. doi:10.1074/jbc.M313321200

Sancenón, V., Puig, S., Mira, H., Thiele, D.J., Peñarrubia, L., 2003. Identification of a copper transporter family in Arabidopsis thaliana. Plant Mol. Biol. 51, 577-587. doi:10.1023/A:1022345507112

Santos, J.H.S, De Bona, F.D., Monteiro, F.A., 2013. Growth and productive responses of tropical grass panicum maximum to nitrate and ammonium supply. Rev. Bras. Zootec. 42, 622-628. doi:10.1590/S151635982013000900003

Sarruge, J.R., Haag, H.P., 1974. Análises químicas em plantas. Piracicaba: ESALQ. 56 p.

SAS Institute. SAS/STAT: Qualification Tools user's guide, version 9.2 Cary, 2008.

Singh, V., Bhatt, I., Aggarwal, A., Tripathi, B.N., Munjal, A.K., Sharma, V., 2010. Proline improves copper tolerance in chickpea (Cicer arietinum). Protoplasma 245, 173-181. doi:10.1007/s00709-010-0178-9 
Tewari, R.K., Kumar, P., Sharma, P.N., 2006. Antioxidant responses to enhanced generation of superoxide anion radical and hydrogen peroxide in the copper-stressed mulberry plants. Planta 223, 1145-1153. doi:10.1007/s00425-005-0160-5

Thounaojam, T.C., Panda, P., Mazumdar, P., Kumar, D., Sharma, G.D., Sahoo, L., Panda, S.K., 2012. Excess copper induced oxidative stress and response of antioxidants in rice. Plant Physiol. Biochem. 53, 33-39. doi:10.1016/j.plaphy.2012.01.006

Velikova, V., Yordanov, I., Edreva, A., 2000. Oxidative stress and some antioxidant systems in acid rain-treated bean plants. Plant Sci. 151, 59-66. doi:10.1016/S0168-9452(99)00197-1

Wang, C., Zhang, S.H., Wang, P.F., Li, W., Lu, J., 2010. Effects of ammonium on the antioxidative response in Hydrilla verticillata (L.f.) royle plants. Ecotoxicol. Environ. Saf. 73, 189-195. doi:10.1016/j.ecoenv.2009.08.012

Wang, S.H., Zhang, H., Zhang, Q., Jin, G.M., Jiang, S.J., Jiang, D., He, Q.Y., Li, Z.P., 2011. Copper-induced oxidative stress and responses of the antioxidant system in roots of Medicago sativa. J. Agron. Crop Sci. 197, 418429. doi:10.1111/j.1439-037X.2011.00476.x

Wightwick, A.M., Salzman, S.A., Reichman, S.M., Allinson, G., Menzies, N.W., 2013. Effects of copper fungicide residues on the microbial function of vineyard soils. Environ. Sci. Pollut. Res. 20, 1574-1585. doi:10.1007/s11356-012-1114-7

Wu, F., Liu, Y., Xia, Y., Shen, Z., Chen, Y., 2011. Copper contamination of soils and vegetables in the vicinity of Jiuhuashan copper mine, China. Environ. Earth Sci. 64, 761-769. doi:10.1007/s12665-010-0897-4

Xia, Y., Qi, Y., Yuan, Y., Wang, G., Cui, J., Chen, Y., Zhang, H., Shen, Z., 2012. Overexpression of Elsholtzia haichowensis metallothionein 1 (EhMT1) in tobacco plants enhances copper tolerance and accumulation in root cytoplasm and decreases hydrogen peroxide production. J. Hazard. Mater. 233-234, 65-71. doi:10.1016/j.jhazmat.2012.06.047 